\title{
OPTOELECTRICAL IMAGING METHODS FOR ORGANIC PHOTOVOLTAIC MATERIALS AND MODULES
}

Jonas Bergqvist

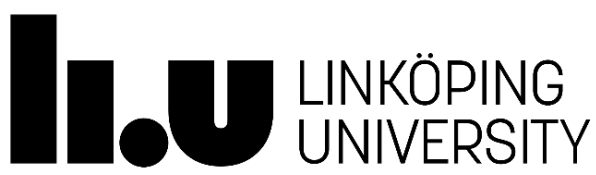

\author{
Biomolecular and organic electronics \\ Division of Applied Physics \\ Department of Physics, Chemistry and Biology \\ Linköping University \\ SE-581 83 Linköping, Sweden
}

Linköping 2015 
Cover image: LED array based photocurrent imaging method for in-line characterization of printed organic solar cells developed during the course of this thesis. Illustration by Cecilia Kornehed.

During the course of research underlying this thesis, Jonas Bergqvist was enrolled in Agora Materiae, a multidisciplinary doctoral program at Linköping University, Sweden.

(C) Copyright 2015 Jonas Bergqvist, unless otherwise noted.

Printed by LiU-Tryck, Linköping, Sweden, 2015

Jonas Bergqvist

OPTOELECTRICAL IMAGING METHODS FOR ORGANIC PHOTOVOLTAIC MATERIALS AND MODULES

ISBN: 978-91-7685-923-0

ISSN: 0345-7524

Linköping Studies in Science and Technology, Dissertation No. 1712 


\section{Abstract}

To achieve a high living standard for all people on Earth access to low cost energy is essential. The massive burning of fossil fuels must be drastically reduced if we are to avoid large changes of our climate. Solar cells are both technologically mature and have the potential to meet the huge demand for renewable energy in many countries. The prices for silicon solar cells have decreased rapidly during the course of this thesis and are now in grid parity in many countries.

However, the potential for even lower energy costs has driven the research on polymer solar cells, a class of thin film solar cells. Polymer solar cells can be produced by roll to roll printing which potentially enables truly low cost solar cells. However, much research and development remain to reach that target.

Polymer solar cells consist of a semiconducting composite material sandwiched between two electrodes, of which one is transparent, to let the light energy in to the semiconductor where it is converted to electric energy. The semiconductor comprise an intimate blend of polymer and fullerenes, where the nanostructure of this blend is crucial for the photo current extraction.

To reach higher solar cell performance the dominating strategy is development and fine tuning of new polymers. To estimate their potential as solar cell materials their optical response have been determined by spectroscopic ellipsometry. Furthermore, optical simulations have been performed where the direction dependency of the optical response of the transparent electrode material PEDOT:PSS have been accounted for. The simulations show reduced electrode losses for light incident at large oblique angles.

Moreover, we have shown that a gentle annealing of the active layer induces a local conformational changes of an amorphous polymer that is beneficial for solar cell performance. The active layer is deposited from solution where the drying kinetics determine the final nanostructure. We have shown that using in-situ photoluminescence phase separation can be detected during the drying process while a reflectance method have been developed to image lateral variations of solvent evaporation rate.

Imaging methods are important tools to detect performance variations over the solar cell area. For this purpose an intermodulation based photo current imaging method have been developed to qualitatively differentiate the major photo current loss mechanisms. In addition, a 1D LED-array photo current imaging method have been developed and verified for high speed in-line characterization of printed organic solar modules. 


\section{Populärvetenskaplig sammanfattning}

För att uppnå en hög levnadsstandard för alla människor på vår jord krävs tillgång till billig energi. Världen står nu inför en gigantisk omställning från fossil till förnyelsebar energi för att undvika stora klimatförändringar. Teknologin med störst potential och teknisk mognad är nyttjandet av solenergi och utbyggnaden har gått snabbt i stora delar av världen. De senaste årens kombination av installationsbidrag och produktionseffektiviseringar har pressat ner tillverkningskostnaderna för kiselsolceller och därmed även kostnaderna för solenergi till motsvarande nätnivå i många länder.

Billigare energi eftersöks dock alltid och här har polymersolceller sin stora potential. Polymersolceller är en typ av tunnfilmssolcell som kan tryckas i stora volymer i klassiska tryckpressar. Med sin lätta vikt och potentiellt låga pris skulle de kunna förse stora delar av jordens fattigare områden med elektrisk energi. Dock kvarstår mycket forskning och utveckling innan det målet kan nås.

Polymersolceller består av ett halvledande kompositmaterial placerat mellan två ledande elektroder, varav en är transparent för att släppa igenom ljusenergin till halvledarlagret där det absorberas och konverteras till elektrisk energi. Kompositmaterialet består av polymerer och fullerener, där nanostrukturen i blandningen mellan dessa är direkt avgörande för hur mycket fotoström som kan extraheras.

För att öka verkningsgraden är den dominerande strategin att syntetisera nya polymerer och utvärdera dessa. För att beräkna maximala prestanda för de nya materialen görs optiska simuleringar, för vilka materialens optiska interaktionsegenskaper behöver bestämmas. Detta har gjorts med spektroskopisk ellipsometri.

Den transparanta elektroden utgörs i tryckta polymersolceller av den ledande polymeren PEDOT:PSS. PEDOT:PSS har olika optiska egenskaper beroende på ljusets infallsvinkel, vilket ej tidigare tagits hänsyn till vid optiska simuleringar, men har inkluderats i denna avhandling, och visar att vid snäva infallsvinklar kan betydande ökningar av fotoströmmen för nära infrarött ljus erhållas.

Vidare har även nanostrukturen hos polymer:fullerenblandningen undersökts. Genom försiktig värmning ökades ordningen lokalt hos materialen vilket ledde till en ökad verkningsgrad i solcellerna.

Formeringen av nanostrukturen i det aktiva lagret sker under intorkning från ett lösningsmedel. Materialen strävar efter att fasseparera vid jämvikt men detta kan undertryckas genom en snabbare torkning. I avhandlingen har metoder för att följa torkprocessen in-situ utvecklats, dels via fotoluminiscens, dels via avbildande reflektometri. Avbildande metoder är viktiga för att upptäcka variationer i prestanda över solcellens yta i färdiga komponenter. En fotoströmsmetod baserad på intermodulation har utvecklats för 
att kunna avbilda den dominerande förlustmekanismen hos fotoströmmen. Med denna kan kvalitativt områden med en viss typ av rekombination utskiljas.

Vid tryckning av polymera solceller genereras snabbt stora volymer. Dessa måste karakteriseras, helst medan de är kvar i tryckmaskinen. För detta ändamål har en fotoströmsavbildande metod baserad på en rad med LED-lampor blinkande vid unika frekvenser utvecklats och metoden har verifierats för in-line karakterisering av tryckta moduler i hög hastighet. 


\section{Acknowledgements}

This thesis would not have been possible without the contribution from many people, both within and outside the academia. I have many people to thank for a very stimulating time during the course of this project.

First of all, thank you Olle for guiding me through this time. Your humor and original ideas have been really encouraging and your ability to refill the group with brilliant minds have really facilitated the work here.

Christian, without you I would never have discovered that science is fun. Thanks! Also thanks for all the fun times outside the uni.

Hans, tack för all tid med mina optiska funderingar och guidning till stringens.

My former office mates Koen and Wolfgang, sharing office with you were both fun and really inspiring. I have learned a lot from the discussions with you.

Mattias, tack för att du släpade med mig på innebandyn och för ett mycket stimulerande arbete med tryckningen. Nästa jul kommer en OPV modul med tomten.

Anders, du är en klippa. Tack för allt skönt tugg och backning!

Camilla, att steka TQ1 med diverse fullerener var visst vår grej. Tack för intressanta diskussioner och projekt!

My roommate Zheng, thanks a lot for all fruitful discussions concerning both solar cells and life in general. It has been a true pleasure to share office with you these years. Armantas, thanks for all discussions and our trip to Hirschegg, and especially for not giving up on my aesthetics.

Kristofer, tack för bra hjälp vid min introduktion till organiska solceller och givande diskussioner.

Erik, förhoppningsvis blir fotoströmsavbildaren den en av de idéer som faktiskt lämnar akademin och blir användbar. Tack för alla inspirerande diskussioner!

Sofie, flyger Alsvid är det till stor del din förtjänst. Olof, tack för ett spännande arbete med PL torkningen.

Daniel, Riccardo and David at KTH, thanks for all discussions and also for bringing intermodulation in to my awareness.

Per och Jonas, tack för en kul tid i solsimulatorkurserna! Det var riktigt häftigt när vi tände den stora!

Bo, tack för all hjälp med mätuppställningar och praktiska problem. Tack också Ingemar för programmering och Hassan för all hjälp med att hitta rätt prylar. 
Niclas, Zaifei, Scott, Lintao, Chiara, Fengling, Deping, Feng, Yuxin, Shuyan, Bo, Chuanfei, Mingtao and Zhongqiang for discussions, measurements and samples and Nadia, Erica and all people passing the Biorgel group over these years.

The Swedish OPV team with Amaia, Renee, Mats A, Zandra, Ergang, Desta, Patrik, Ellen, Mats F, Martijn and all others. Our meetings and discussions have been really inspiring.

The OPV printing crew with Wanzhu, Ouyang, Thomas and Jim. Being part of the highly applied research together with you has been truly stimulating.

Mikael och Anna-Maria, tack för all hjälp med pappersarbetet.

Per-Olof, Kirstin and the first Student Council of Agora Materia. Thanks for all the fun times!

Arne och Jonas, för ert engagemang kring patent och kommersialiseringsfrågor.

Kaffeklubben med Sara, Viktor, Freddy, Katarina, Per, Gunnar, Jonas, Leffe, Fredrik, Skallberg, Robban, Robban, Karin, Camilla, Staffan, Peter, Kristoffer, Abeni, Andreas, Lina, Linda, Abdel och alla gamla och nya medlemmar. Kaffe- och lunchbrejken med tillhörande urspårade diskussioner har verkligen varit en av de stora förmånerna den här tiden! Även Daniel, Pontus, Björn, Stefan, Nate och alla andra trevliga personer som rör sig och sprider glädje i IFMs korridorer.

Nina och Cissi som försåg mig med kaffe och mat sista månaden.

\section{Ettan}

Norrköpingsgrabbarna och pluggpolarna för sköna distraktioner.

IFK Norrköping, en toppstrid hade räckt som distraktion... guld var en bonus

Familjen med mor och far, tack för att ni alltid finns där, ni är fantastiska! Anna och Gustav, efter jul blir det många fler stockholmsresor och långt sommarhäng på Öland. Anders och Gunilla tack för all hjälp med barnvaktande och för att ni är underbara svärföräldrar. Fredrik och Kajsa, snart är det försäsong och då ses vi i Norpan.

Viggo och Siri, finaste vildarna på jorden! Jag vet att jag varit urtråkig ett par månader nu, men det var också de sista månaderna, det lovar jag er!!

Mia, orden räcker inte tillnärmelsevis. Du är helt fantastisk!! Tack! 


\section{Papers included in the thesis:}

\section{Paper 1}

Comparison of selenophene and thienothiophene incorporation into pentacyclic lactambased conjugated polymers for organic solar cells

R. Kroon, A. Melianas, W. Zhuang, J. Bergqvist, A. D. de Z. Mendaza, T. T. Steckler, L. Yu, S. J. Bradley, C. Musumeci, D. Gedafaw, T. P. Nann, A. Amassian, C. Müller, O. Inganäs and M. R. Andersson, Polymer Chemistry (2015)

\section{Paper 2}

Uniaxial anisotropy in PEDOT:PSS electrodes enhances the photo current at oblique incidence in organic solar cells

J. Bergqvist, H. Arwin, O. Inganäs, In manuscript

\section{Paper 3}

In situ reflectance imaging of organic thin film formation from solution deposition

J. Bergqvist, S.A. Mauger, K. Tvingstedt, H. Arwin, O. Inganäs, Solar Energy Materials and Solar Cells 114 (2013)

\section{Paper 4}

Lateral Phase Separation Gradients in Spin-Coated Thin Films of High-Performance Polymer:Fullerene Photovoltaic Blends

L. Hou, E. Wang, J. Bergqvist, B.V. Andersson, Z. Wang, C. Müller, M. Campoy-Quiles, M. R. Andersson, F Zhang, O Inganäs, Advanced Functional Materials 21 (2011)

\section{Paper 5}

Time-resolved morphology formation of solution cast polymer:fullerene blends revealed by in-situ photoluminescence spectroscopy

J. Bergqvist, A. Melianas, O. Andersson, C. Lindqvist, C. Musumeci, O. Inganäs, In manuscript

\section{Paper 6}

Sub-glass transition annealing enhances polymer solar cell performance

J. Bergqvist, C. Lindqvist, O. Backe, Z. Ma, Z. Tang, W. Tress, S. Gustafsson, E. Wang, E. Olsson, M.R. Andersson, O. Inganäs, C. Müller, Journal of Materials Chemistry A. 2 (2014)

\section{Paper 7}

New method for lateral mapping of bimolecular recombination in thin film organic solar cells

J. Bergqvist, W. Tress, A. Melianas, Z. Tang, D.Haviland, O. Inganäs, Submitted

\section{Paper 8}

LED array scanner for inline characterisation of thin film photovoltaic modules J. Bergqvist, E. Tholén, O. Inganäs, In manuscript 


\section{Contributions to included papers}

\section{Paper 1}

Measured optical constants, device reflectance and calculated IQE.

\section{Paper 2}

All the work.

\section{Paper 3}

All the work.

\section{Paper 4}

Measured the reflectance imaging and photocurrent imaging and analyzed the data. Contributed to the writing.

\section{Paper 5}

Designed the in-situ experiments. Made the PL experiments together with Camilla Lindqvist (Chalmers) and Olof Andersson (LiU). PL data was also recorded during the master thesis by Olof Andersson (LiU). Analyzed the data. Wrote the manuscript.

\section{Paper 6}

Shared first authorship with Camilla Lindqvist (Chalmers). Characterized the solar cells, planned and summarized the spectroscopy measurements. Wrote the first draft, except for the imaging part.

\section{Paper 7}

Designed and performed the experiments. Wrote the experiments section and parts of the introduction.

\section{Paper 8}

All the work.

\section{Papers not included in the thesis}

Müller, C., Bergqvist, J., Vandewal, K., Tvingstedt, K., Anselmo, A. S., Magnusson, R., Alonso, M. I., Moons, E., Arwin, H., Campoy-Quiles, M., Inganäs, O., Phase behaviour of liquidcrystalline polymer/fullerene organic photovoltaic blends: thermal stability and miscibility, J. Mater. Chem. 2011;21

Vandewal, K., Ma, Z., Bergqvist, J., Tang, Z., Wang, E., Henriksson, P., Tvingstedt, K., Andersson, M.R., Zhang, F., Quantification of quantum efficiency and energy losses in low bandgap polymer: Fullerene solar cells with high open-circuit voltage, Adv. Funct. Mater. 2012; 22(16) 
Tang, Z., George, Z., Ma, Z., Bergqvist, J., Tvingstedt, K., Vandewal, K., Wang, E., Andersson, L.M., Andersson, M.R., Zhang, F., Inganäs, O., Semi-transparent tandem organic solar cells with 90\% internal quantum efficiency, Adv. Energy Mater. 2012; 2(12)

Shao, S., Liu, J., Bergqvist, J., Shi, S., Veit, C., Würfel, U., Xie, Z., Zhang, F., In Situ Formation of MoO3 in PEDOT:PSS Matrix: A Facile Way to Produce a Smooth and Less Hygroscopic Hole Transport Layer for Highly Stable Polymer Bulk Heterojunction Solar Cells, Adv. Energy Mater. 2013; 3(3)

Wang, E., Bergqvist, J., Vandewal, K., Ma, Z., Hou, L., Lundin, A., Himmelberger, S., Salleo, A., Müller, C., Inganäs, O., Zhang, F., Andersson, M.R., Conformational disorder enhances solubility and photovoltaic performance of a thiophene-quinoxaline copolymer, Adv. Energy Mater. 2013; $3(6)$

Tang, Z., Elfwing, A., Bergqvist, J., Tress, W., Inganäs, O., Light trapping with dielectric scatterers in single- and tandem-junction organic solar cells, Adv. Energy Mater. 2013; 3(12)

Ma, Z., Sun, W., Himmelberger, S., Vandewal, K., Tang, Z., Bergqvist, J., Salleo, A., Andreasen, J.W., Inganäs, O., Andersson, M.R., Müller, C., Zhang, F., Wang, E., Structure-property relationships of oligothiophene-isoindigo polymers for efficient bulk-heterojunction solar cells, Energy Environ. Sci. 2014; 7(1)

Ma, Z., Dang, D., Tang, Z., Gedefaw, D., Bergqvist, J., Zhu, W., Mammo, W., Andersson, M.R., Inganäs, O., Zhang, F., Wang, E., A facile method to enhance photovoltaic performance of benzodithiophene- isoindigo polymers by inserting bithiophene spacer, Adv. Energy Mater. 2014; $4(6)$.

Lindqvist, C., Bergqvist, J., Bäcke, O., Gustafsson, S., Wang, E., Olsson, E., Inganäs, O., Andersson, M.R., Müller, C., Fullerene mixtures enhance the thermal stability of a non-crystalline polymer solar cell blend, Appl. Phys. Lett. 2014; 104(15).

Lindqvist, C., Bergqvist, J., Feng, C.-C., Gustafsson, S., Bäcke, O., Treat, N.D., Bounioux, C., Henriksson, P., Kroon, R., Wang, E., Sanz-Velasco, A., Kristiansen, P.M., Stingelin, N., Olsson, E., Inganäs, O., Andersson, M.R., Müller, C., Fullerene nucleating agents: A route towards thermally stable photovoltaic blends, Adv. Energy Mater. 2014; 4(9).

Kroon, R., Diaz De Zerio Mendaza, A., Himmelberger, S., Bergqvist, J., Bäcke, O., Faria, G.C., Gao, F., Obaid, A., Zhuang, W., Gedefaw, D., Olsson, E., Inganäs, O., Salleo, A., Müller, C., Andersson, M.R., A new tetracyclic lactam building block for thick, broad-bandgap photovoltaics, J. Am. Chem. Soc. 2014; 136(33)

Diaz De Zerio Mendaza, A., Bergqvist, J., Bäcke, O., Lindqvist, C., Kroon, R., Gao, F., Andersson, M.R., Olsson, E., Inganäs, O., Müller, C., Neat C60:C70 buckminsterfullerene mixtures enhance polymer solar cell performance, J. Mater. Chem. A. 2014; 2(35)

Borgani, R., Forchheimer, D., Bergqvist, J., Thorén, P.-A., Inganäs, O., Haviland, D.B., Intermodulation electrostatic force microscopy for imaging surface photo-voltage, Appl. Phys. Lett. 2014; 105(14).

Tang, Z., Liu, B., Melianas, A., Bergqvist, J., Tress, W., Bao, Q., Qian, D., Inganäs, O., Zhang, F., A New Fullerene-Free Bulk-Heterojunction System for Efficient High-Voltage and High-Fill Factor Solution-Processed Organic Photovoltaics, Adv. Mater., 2015; 27 


\section{Contents}

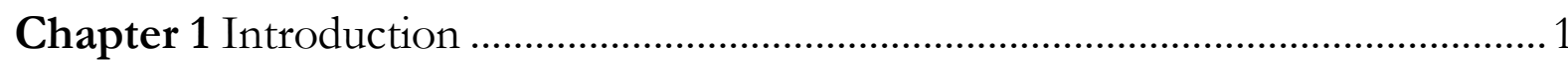

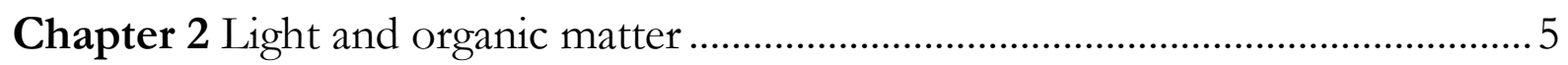

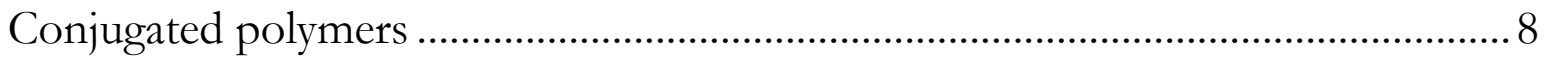

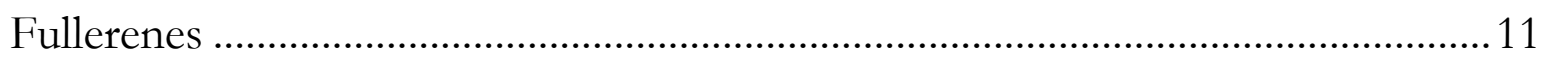

Chapter 3 Polymer solar cells.................................................................................13

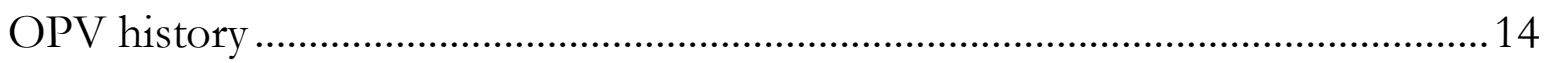

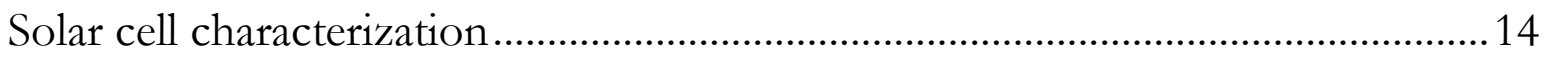

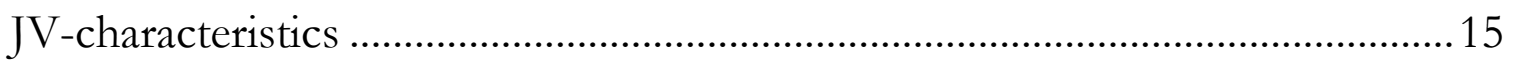

Theoretical conversion limit.............................................................................16

External quantum efficiency............................................................................... 17

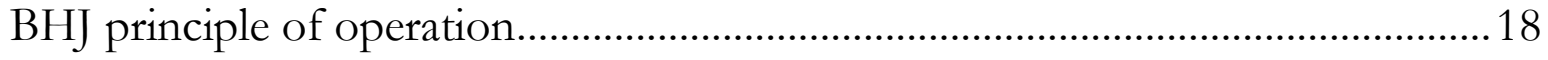

Exciton diffusion and dissociation ...............................................................18

Charge transport and collection..........................................................................19

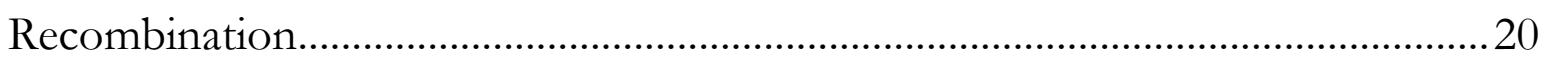

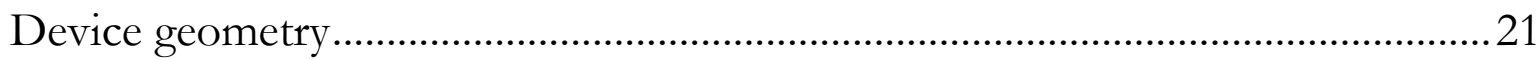

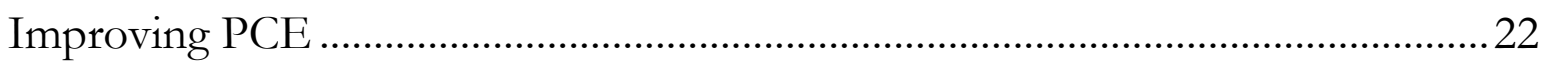

Chapter 4 Optical modelling......................................................................................23

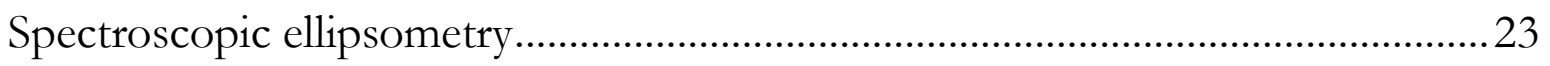

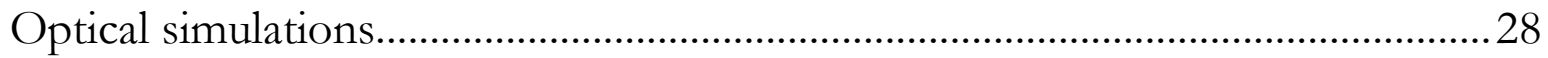

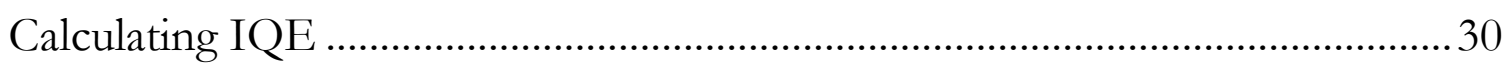

Anisotropy in PEDOT:PSS............................................................................ 31

Chapter 5 Active layer morphology ……………………........................................... 33

Morphology formation from solution ........................................................................ 33

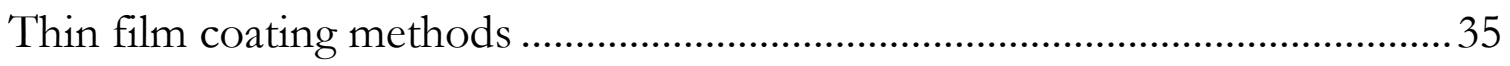

In-situ morphology monitoring............................................................................... 36

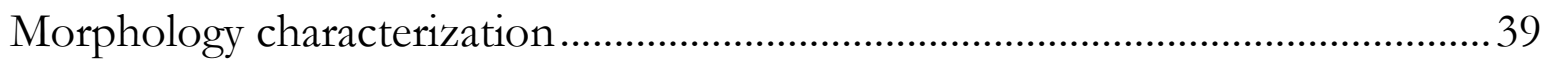

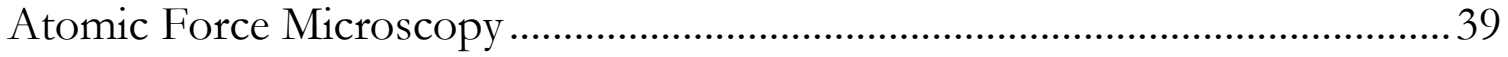


Transmission Electron Microscopy........................................................................ 39

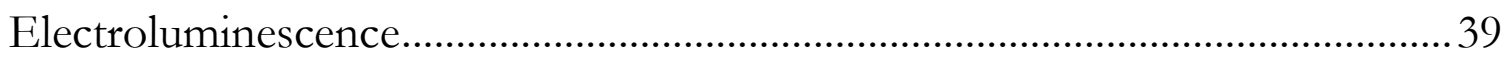

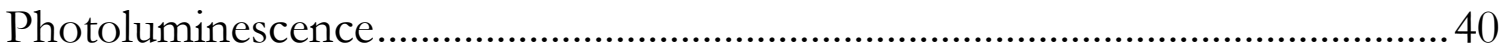

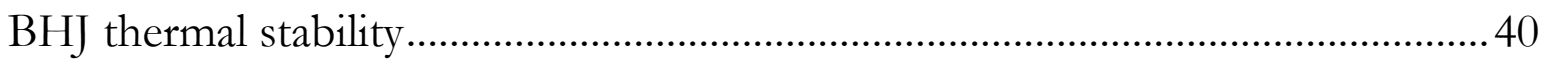

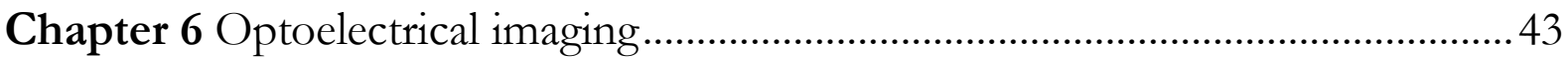

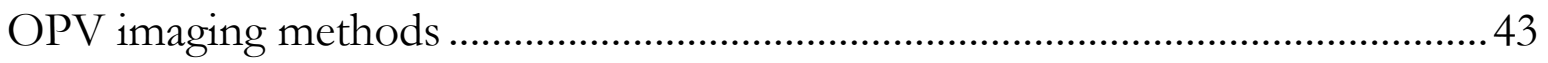

Lock-in thermography............................................................................................ 43

Luminescence imaging ........................................................................................ 43

Photocurrent imaging.......................................................................................... 44

Recombination imaging................................................................................... 46

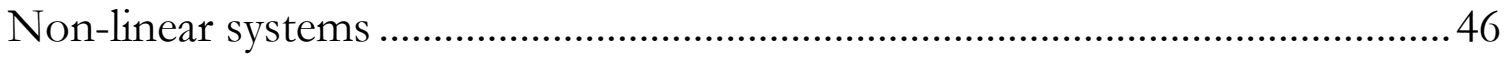

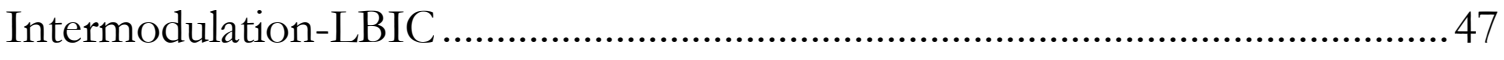

Imaging of modules ............................................................................................. 49

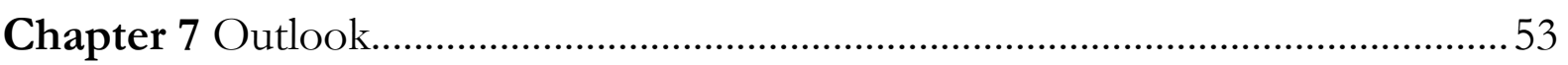

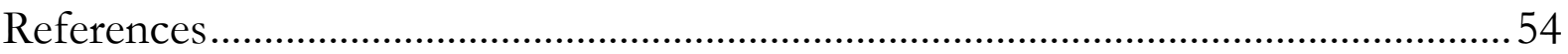




\section{Chapter 1}

\section{Introduction}

The continuous energy supply from the Sun enables a tremendous diversity and number of life forms on our planet. The fortunate combination of the distance to the sun and an atmosphere keeps our planet at a life friendly mean temperature of $15^{\circ} \mathrm{C}$. Over the past 10000 years Earth has had a particular stable climate well suited for the progress of man. Over the past centuries the industrial revolution has brought us a material comfort never seen before in history. However, the facilitator has been, and still is, an energy supply from massive burning of fossil hydrocarbons and thus a polluted planet. Much of the environmentally hazardous emissions have been addressed and solved, like the freons degrading the protective ozone layer. However, one of the main problems when burning fossil fuels has not yet been resolved, the emission of carbon dioxide $\left(\mathrm{CO}_{2}\right)$.

$\mathrm{CO}_{2}$ emission contributes to the greenhouse effect on Earth and thereby global warming according to most climate researchers. The amount of $\mathrm{CO}_{2}$ in the atmosphere has gradually increased from just above $300 \mathrm{ppm}$ in the 1950ies, to above $400 \mathrm{ppm}$ in 2015 [1]. The global mean temperature and climate have varied over the history of Earth, but the Earth we know today most people would like to keep. To retain this Earth with a resilient climate, it is believed that the global temperature increase should be kept below $2^{\circ} \mathrm{C}$ relative to the pre-industrialization value, requiring drastically reduced $\mathrm{CO}_{2}$ emissions [2].

The steady state temperature of Earth is determined by the power balance between the incident radiation from the sun and the emitted radiation from earth. From this balance the mean temperature of Earth should be $2^{\circ} \mathrm{C}$. However, reradiation by the atmosphere allows for the more comfortable $15^{\circ} \mathrm{C}$. The incident radiated energy from the $5800 \mathrm{~K}$ hot sun is mainly contained in the visible spectrum, while the reradiated energy by the cooler Earth peaks at $10 \mu \mathrm{m}$, with a long tail towards $30 \mu \mathrm{m}$. The atmosphere contains much water vapor that also is the main cause for the greenhouse effect. The water absorption has a window between 8 and $20 \mu \mathrm{m}$ letting heat radiation pass out to space. However, $\mathrm{CO}_{2}$ has an absorption band in this window as illustrated in Figure 1.1 and thus an increase of atmospheric $\mathrm{CO}_{2}$ will partly close the heat emission window. Thus increasing concentrations of $\mathrm{CO}_{2}$ will increase the equilibrium temperature. 
Irrespective of the temperature increase, there is a finite storage of oil, gas and coal on Earth. The energy return of invested energy (EROI) for oil has decreased from 100:1 in 1930 to 20:1 in 2000 [3]. This is a consequence of depletion of the easy available sources. Thus the future energy supply needs to be extended with alternative sources, if not due to reduced EROI but because if the carbon combustion all over the world would be at German levels, we would eventually run out of oxygen [4].

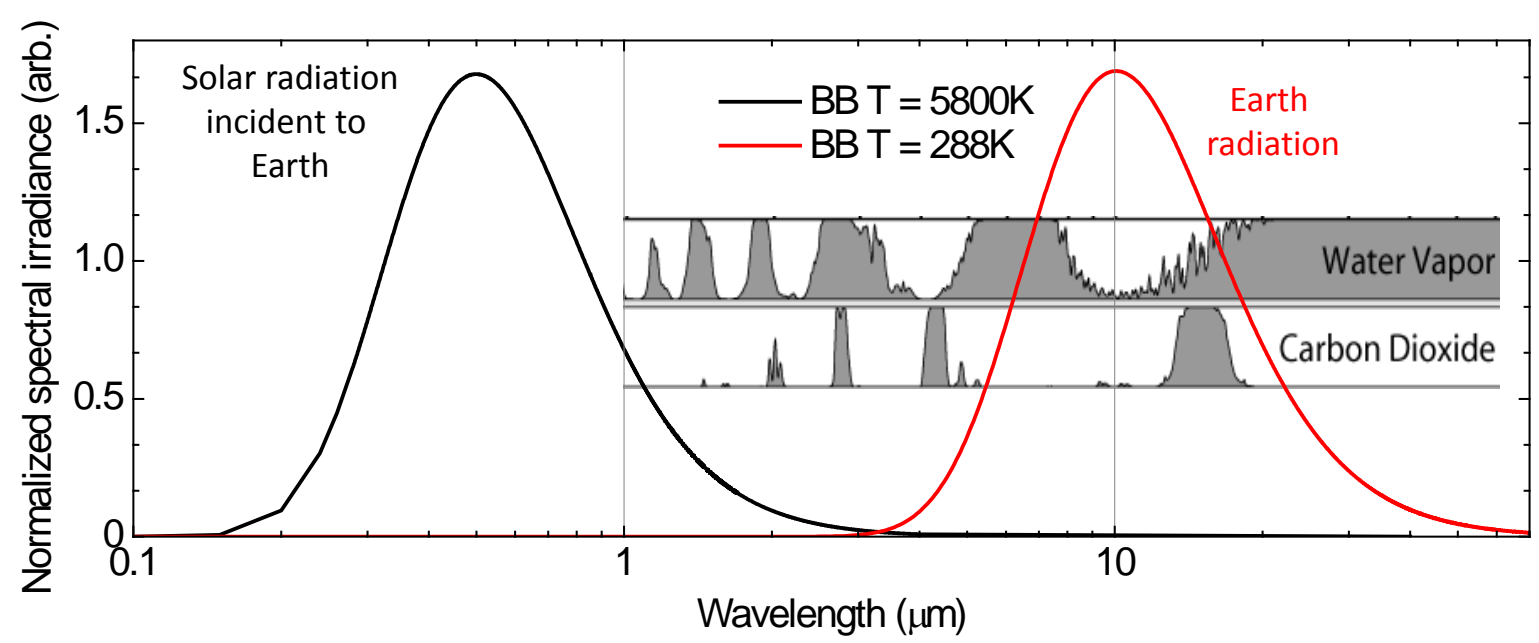

Figure 1.1 Black body radiation from a $5800 \mathrm{~K}$ (black) and $288 \mathrm{~K}$ (red) hot body. The inset shows the absorption bands of $\mathrm{H}_{2} \mathrm{O}$ and $\mathrm{CO}_{2}$ and the overlap between Earth radiation and the $\mathrm{CO}_{2}$ absorption. (Gas absorption image adapted from Robert A. Rohde)

Available alternative energy sources are hydro, wind, nuclear, geo, tidal and solar power. Fusion and fourth generation nuclear power are here not considered as they are not currently available. The human power demand was in 200513 TW and is expected to double until 2050. 13 TW corresponds to over 10000 new nuclear power plants which has to be considered impossible. Hydropower already uses $2 / 3$ of the available resources while tidal, wind and geo power has $\sim 2 \mathrm{TW}$ practically available power each [5]. The sun provides $1340 \mathrm{~W} / \mathrm{m}^{2}$, or $173000 \mathrm{TW}$ on the illuminated cross section of Earth. After atmosphere absorption and scattering $120000 \mathrm{TW}$ still remains. Thus, solar energy is a highly viable solution for renewable energy.

Solar energy can be converted to electric energy directly via solar cells. The majority of solar cells are produced from crystalline silicon and have experienced a drastic price drop over the past years due to installation subsidies and an up scaled and more effective production. A turn-key solar cell system today reaches grid parity in many countries. 
When this project started the silicon solar prices had started to drop, but the main motivation for exploring alternative materials for photovoltaics was still to reduce the production cost.

This thesis concerns polymer solar cells, a branch of organic photovoltaics (OPV), being one of the novel technologies constituting the third generation solar cells. The main advantage compared to inorganic silicon solar cells are the potentially scalable production volumes and low energy input. This is easily understood by comparing the production processes where for organics a few $100 \mathrm{~nm}$ thick paint layers are printed in a standard industry roll to roll printing machine, while to produce a silicon solar cell, silicon dioxide (sand) must first be melted and then grown into a perfect crystal.

Polymer solar cells have a photoactive layer comprising a nanoscale blend of polymers and fullerenes. The work in this thesis aims to better understand the formation and possible manipulation of the nanostructure in the photoactive layer. Further, to investigate the possibilities and limitations of novel polymers and solar cell geometries optical modelling and material characterization have been performed. Finally, as the technology matures larger areas are produced. Thus, large scale characterization methods are required, which is why optoelectrical imaging methods have been developed to identify channels of efficiency loss in devices, and for large scale characterization of solar modules.

The next two chapters gives a brief introduction to light matter interactions and polymer solar cells. The three following chapters concern optical modelling, active layer morphology and imaging methods. In conjunction to these chapters also the main results from each included paper are presented. The last chapter gives a short outlook based on the results in this thesis and for polymer solar cells in general. 


\section{Chapter 2}

\section{Light and organic matter}

Energy is transported from the sun to earth as light that can be described either in terms of the particles photons, or as transverse electromagnetic waves. Propagation of electric and magnetic plane waves are solutions to Maxwell's equations [6]:

$$
\begin{gathered}
\nabla \times \mathbf{H}=\mathbf{J}+\frac{\partial \mathbf{D}}{\partial t} \\
\nabla \times \mathbf{E}=-\frac{\partial \mathbf{B}}{\partial t} \\
\nabla \cdot \mathbf{D}=\rho \\
\nabla \cdot \mathbf{B}=0
\end{gathered}
$$

where $\mathbf{H}$ and $\mathbf{E}$ are the magnetic and electric field strengths, $\mathbf{D}$ the electric displacement field and $\mathbf{B}$ the magnetic flux density. $\mathbf{J}$ is the electric current density and $\rho$ is the charge density. The interaction of time-harmonic fields with matter at rest are described by the material equations [7]:

$$
\begin{gathered}
\mathbf{B}=\tilde{\mu} \mu_{0} \mathbf{H} \\
\mathbf{D}=\tilde{\varepsilon} \varepsilon_{0} \mathbf{E} \\
\mathbf{J}=\tilde{\sigma} \mathbf{E}
\end{gathered}
$$

where $\mu_{0}$ and $\varepsilon_{0}$ are the permeability and permittivity, respectively of free space, $\tilde{\mu}$ is the relative magnetic permeability tensor, $\tilde{\varepsilon}$ the relative dielectric tensor and $\tilde{\sigma}$ the optical conductivity tensor. $\tilde{\mu}, \tilde{\varepsilon}$ and $\tilde{\sigma}$ are all $3 \times 3$ tensors. For non-magnetic materials, as is the case for the materials discussed in this thesis, $\tilde{\mu}$ is unity and the optical response of a material is described by $\tilde{\varepsilon}$ and $\tilde{\sigma}$. 
Combining the material equations with (1.1) and (1.2) for a homogenous isotropic medium and assuming a time-harmonic wave with the time dependence $e^{-i \omega t}$, where $\omega$ is the angular frequency, results in the wave equation

$$
\nabla^{2} \mathbf{E}+\omega^{2}\left(\frac{i \sigma}{\omega \varepsilon_{0}}+\varepsilon\right) \varepsilon_{0} \mu_{0} \mathbf{E}=0
$$

The effective electric permittivity is defined as

$$
\varepsilon_{e f f}=\left(\frac{i \sigma}{\omega \varepsilon_{0}}+\varepsilon\right)
$$

to account for both free and bound charges in a single parameter. We now drop the eff in $\varepsilon_{\text {eff }}$ and the linear optical material response is completely described by the dielectric tensor $\varepsilon$

$$
\varepsilon=\left(\begin{array}{ccc}
\varepsilon_{i i} & \varepsilon_{i j} & \varepsilon_{i k} \\
\varepsilon_{j i} & \varepsilon_{j j} & \varepsilon_{j k} \\
\varepsilon_{k i} & \varepsilon_{k j} & \varepsilon_{k k}
\end{array}\right)
$$

For isotropic materials with direction independent light response the off diagonal elements vanish and $\varepsilon_{i i}=\varepsilon_{j j}=\varepsilon_{k k}$. In most materials $\varepsilon$ can be diagonalized by rotation of coordinate systems. Materials with a direction dependent optical response are biaxially anisotropic if $\varepsilon_{i i} \neq \varepsilon_{j j} \neq \varepsilon_{k k}$ and uniaxially anisotropic when only one direction differs from the others.

For dispersive media, including basically all media but vacuum, $\varepsilon$ is a function of the angular frequency $\omega$. In isotropic media $\varepsilon$ reduces to the scalar dielectric function

$$
\varepsilon(\omega)=\varepsilon_{1}(\omega)+i \varepsilon_{2}(\omega)
$$

where $\varepsilon_{1}$ is the real part and $\varepsilon_{2}$ the complex part of the dielectric function. $\varepsilon_{1}$ and $\varepsilon_{2}$ are related to each other via the Kramers-Kronig relation [8].

From the definition of the speed of light in free space, $c_{0}^{2}=1 / \varepsilon_{0} \mu_{0}$ and introducing the wave number $k_{0}$

$$
k_{0}^{2}=\omega^{2} \varepsilon_{0} \mu_{0}=\frac{\omega^{2}}{c_{0}^{2}}=\left(\frac{2 \pi}{\lambda}\right)^{2}
$$

where $\lambda$ is the wavelength of light in vacuum Eq. (1.8) reduces to a more compact equation

$$
\left(\nabla^{2}+\varepsilon k_{0}^{2}\right) \mathbf{E}=0
$$

For an electromagnetic wave propagating in the z-direction in a cartesian coordinate system the electric field is expressed as 


$$
\mathbf{E}=\mathfrak{R}\left[\mathbf{E}_{\mathbf{0}} e^{i \sqrt{\varepsilon} k_{0} z-i \omega t}\right]
$$

where $\mathfrak{R}$ indicates the real part. It is convenient to replace the material property $\varepsilon$ with the refractive index $N=\sqrt{\varepsilon}$, where $N=n+i k$. Here $n$ is often called the refractive index but more correctly is the real part of the refractive index and $k$ is the extinction coefficient. Inserting $N=n+i k$ in (1.14) gives

$$
\mathbf{E}=\mathfrak{R}\left[\mathbf{E}_{\mathbf{0}} e^{-k_{0} k z} e^{i\left(k_{0} n z-\omega t\right)}\right]
$$

where $k_{0} k$ defines the attenuation of the electric field amplitude inside the medium, whereas $n$ determines the speed of light $v$ inside the medium

$$
v=\frac{c_{0}}{n}
$$

Hence, $n$ and $k$ defines the interaction between an electromagnetic wave and the matter it propagates within.

This thesis covers polymer solar cells and thus the conversion of solar energy to electrical energy. The energy flux of an electromagnetic wave, its irradiance, is described by the time averaged Poynting vector $\langle\mathbf{S}\rangle$,

$$
<\mathbf{S}>=\frac{1}{2} \mathfrak{R}\left(\mathbf{E} \times \mathbf{H}^{*}\right)
$$

where $\Re$ is the real part and * the complex conjugate. For isotropic media $\mathbf{S}$ is parallel to the direction of the wave vector which means that the energy propagates in the same direction as the wave fronts and is

$$
<\mathbf{S}>=\frac{1}{2} c_{0} \varepsilon_{0} n\left|\mathbf{E}_{\mathbf{0}}\right|^{2} e^{-2 k_{0} k z} \hat{\mathbf{z}}
$$

The calculated irradiance can be used to calculate the light transmission through an absorbing medium according to the Beer-Lambert law

$$
I=I_{0} e^{-\alpha d}
$$

where $I$ is the transmitted irradiance at depth $d, I_{0}$ the irradiance for $d=0$ and $\alpha=2 k_{0} k=\frac{4 \pi k}{\lambda}$ is the absorption coefficient.

To describe light interaction with matter it is also convenient to express the energy carried by each photon, a massless particle carrying the electromagnetic energy $E_{P}=h c_{0} / \lambda$, where $h$ is Planck's constant and $c_{0}$ the speed of light.

Thus, the light energy irradiating a solar cell can now be determined along with the light interaction with matter via the refractive index. However, before we continue 
to the polymer solar cells we will briefly introduce the conjugated polymers constituting the energy converting material in polymer solar cells.

\section{Conjugated polymers}

A polymer is a macromolecule with identical small molecules repeatedly covalently bonded to each other. The small molecule is here referred to as a mer and many mers becomes a polymer. Polymers with alternating single and double bonds along its backbone are referred to as conjugated polymers. The simplest example is polyacetylene where the mer is shown in Figure 2.1.

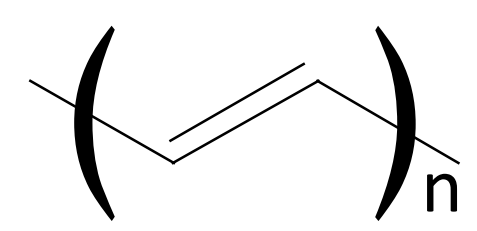

Figure 2.1 Molecular structure of polyacetylene

Organic conjugated polymers have a carbon backbone where the occupied atomic orbitals in carbon are $1 \mathrm{~s}^{2} 2 \mathrm{~s}^{2} 2 \mathrm{p}_{\mathrm{x}}{ }^{1} 2 \mathrm{p}_{\mathrm{y}}{ }^{1}$ and the $2 \mathrm{~s}$ and $2 \mathrm{p}$ constitutes the valence electrons. By promoting one electron from $2 \mathrm{~s}$ to $2 \mathrm{p}_{z}$ the atom has 4 unpaired electrons. The $2 \mathrm{~s}_{2} \mathrm{p}_{\mathrm{x}} 2 \mathrm{p}_{\mathrm{y}}$ carbon atoms in the polyacetylene backbone are $\mathrm{sp}^{2}$ hybridized in three covalent $\sigma$-bonds (one carbon on each side and one hydrogen) per carbon, whereas the $2 \mathrm{p}_{z}$ electrons form weaker $\pi$-bonds illustrated in Figure 2.2a. The $\pi$-orbital is delocalized over the full conjugation length of the polymer, where a torsion on the chain will break the conjugation. Further antibonding $\sigma^{*}$ - and $\pi^{*}$ orbitals are formed at higher energy levels from the c-c double bond. Electronic transitions are possible between both $\sigma-\sigma^{*}$ and $\pi-\pi^{*}$ shown in Figure 2.2b. [BB1]
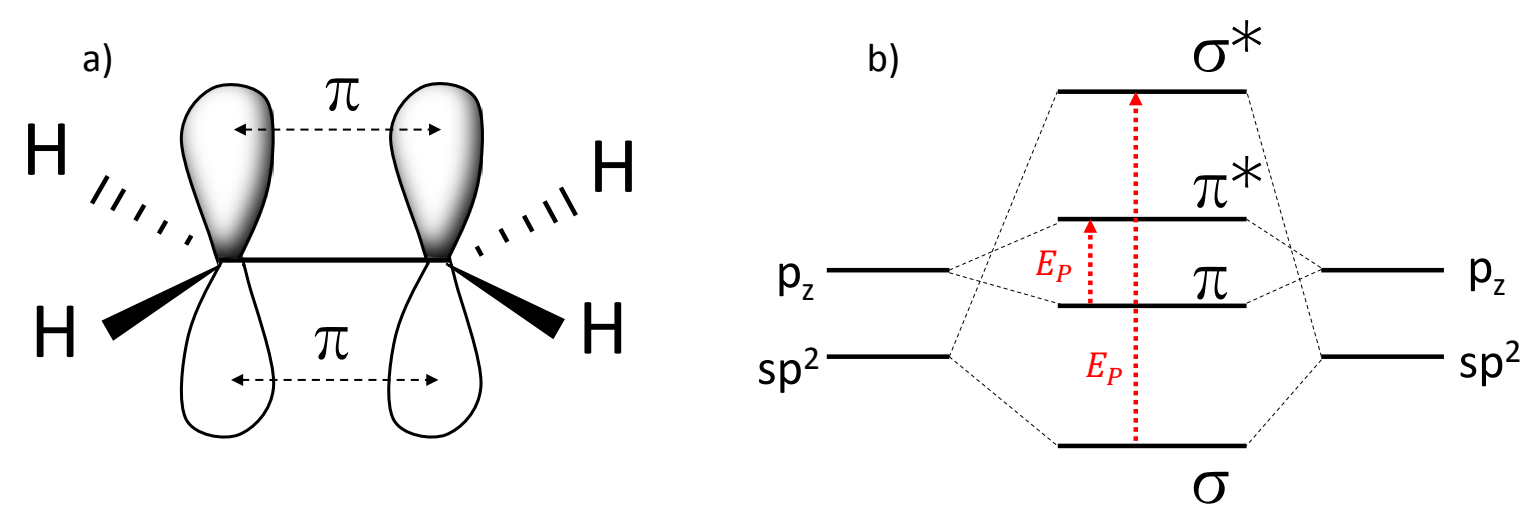

Figure 2.2 (a) Illustration of carbon-carbon $\pi$-bond where the orbitals are in phase. (b) The splitting of energy levels to $\sigma$ - and $\pi$ - molecular orbitals 
A $\sigma-\sigma^{*}$ transition needs high energy and may degrade the polymer as it implies destabilizing a covalent bond, typically induced by ultraviolet light, whereas a $\pi-\pi^{*}$ transition is less likely to degrade the molecule. By careful design of the polymer the $\pi-\pi^{*}$ energy gap can be tuned down to $1-2 \mathrm{eV}$. Thus, conjugated polymers have a bandgap and can be regarded as semiconductors with the Fermi energy in the middle of the bandgap and thus filled $\sigma$ - and $\pi$-orbitals and empty $\sigma^{*}$ - and $\pi^{*}$-orbitals.

Semiconducting conjugated polymers commonly have a low electric conductivity. However, doping of polyacetylene was 1977 shown to drastically increase the conductivity [9] and the discovery was rewarded with the Nobel Prize in 2000. The polymer poly(3,4-ethylenedioxythiophene):poly(styrenesulfonate) PEDOT:PSS shown in Figure 2.3 have reached a conductivity over $3000 \mathrm{~S} \mathrm{~cm}^{-1}[10,11]$ and is commonly used as electrode material in polymer solar cells.

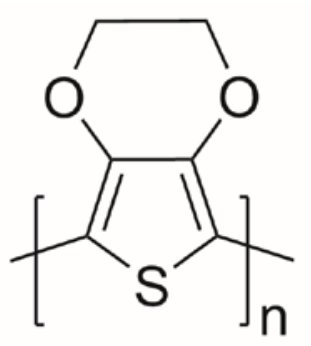

Figure 2.3 PEDOT and PSS

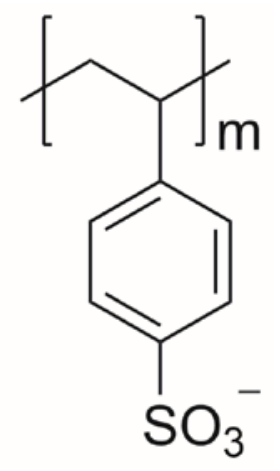

Comparing polymeric semiconductors to inorganic, the highest occupied molecular orbital (HOMO) and the lowest unoccupied molecular orbital (LUMO) are equivalent to the edges of the valence and conduction band respectively. Thus, the energetic difference between HOMO and LUMO defines the bandgap, $E_{g}$, of the conjugated polymer. An enhanced conjugation length from enhanced molecular planarity or aggregation results in an enhanced conjugation length and thus a lower $E_{g}$.

Photons with $E_{P}>E_{g}$ can excite an electron over the bandgap and have a probability to be absorbed by the polymer, where the probability for absorption in bulk material is a function of the material thickness $d$ according to the Beer-Lambert law. Absorption of a photon promotes an electron to a higher energy level. The absence of an electron leaves a positively charged hole and the attractive Coulomb force between the hole and the negatively charged electron forms an exciton. The attraction reduces the energy of the exciton relative to free charges where this energy difference is the exciton binding energy. In inorganic semiconductors the binding energy is low due to efficient screening of the Coulomb potential and the excitons 
can easily be split into free charges, while in organics the binding energy is higher, commonly a few hundred meV [12].

Conjugated polymers have additional electronic and vibrational states above the LUMO. Thus, after absorption of a high energy photon, it will thermalize to the LUMO edge and the subsequent relaxation over the bandgap has a probability to emit a photon, illustrated in the Jablonski diagram in Figure 2.4a. After thermalization the photon emission occurs at a lower energy, or longer wavelengths, compared to the absorption. The shift is known as a Stokes shift. The absorption and emission spectrum of a typical conjugated polymer used for solar cells are shown in Figure 2.4b.
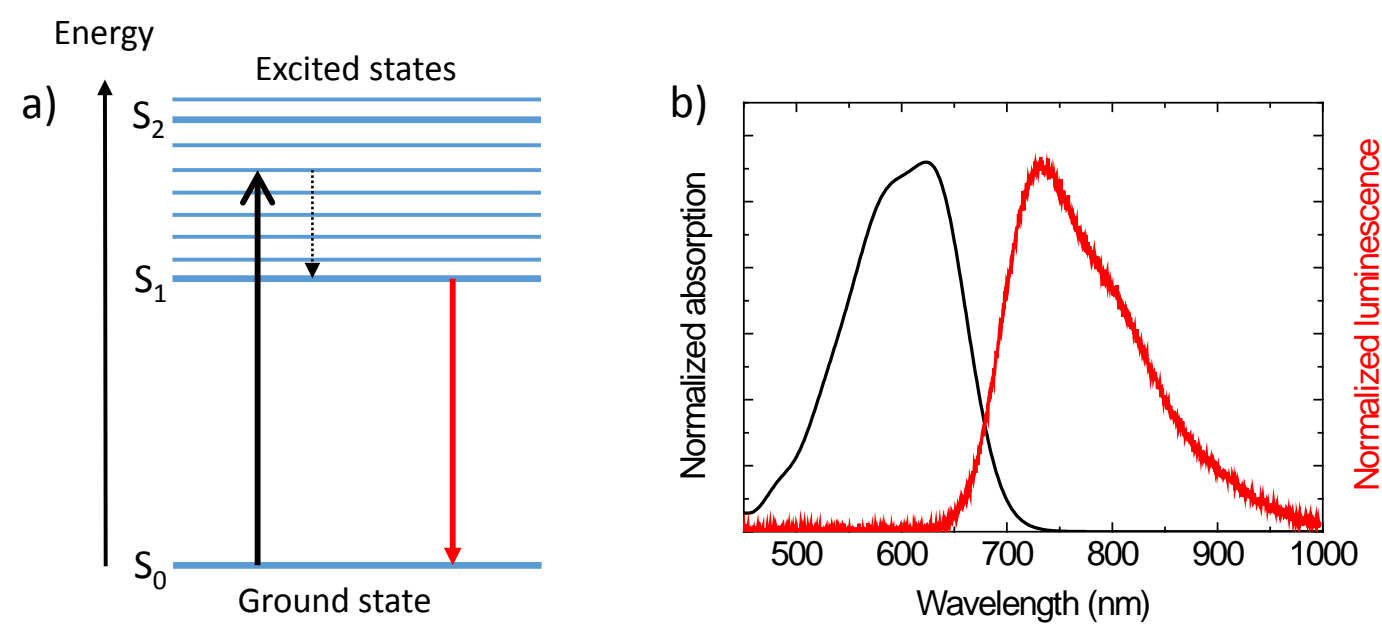

Figure 2.4 (a) Jablonski diagram showing absorption, thermalization and emission. (b) Absorption and photoluminescence spectrum for the polymer TQ1 (see next page for molecular structure ).

By adding soluble side groups to the backbone, conjugated polymers are solubilized in common organic solvents. This makes them processable and suitable for thin film processing via ink deposition by different coating techniques.

The solid state of polymers range from completely amorphous to partly crystalline, or semi-crystalline. Amorphous polymers have a random chain orientation and the solid state is referred to as the glassy state. At an elevated temperature known as the glass transition temperature, $T_{g}$, amorphous polymers softens gradually to a rubbery state permitting chain mobility and geometrical change. Thus $T_{g}$ can be detected by a change in the specific volume. Semicrystalline polymers partly fold and align into short range crystals, but display a weaker $T_{g}$ and melt at the melting temperature $T_{m}$. 


\section{Fullerenes}

The low electric conductivity and strongly bound excitons in conjugated polymers limits the material usage for solar cell applications. However, as discussed in the next chapter, by introducing a material with a stronger electron affinity this can be overcome. Fullerenes display a high conductivity and crystallizes after annealing at elevated temperatures [13], but have a poor solubility in most solvents. The addition of soluble side groups drastically increases the solubility and can also be used to tune the HOMO and LUMO levels [14]. The most commonly used fullerene derivatives for polymer solar cell applications are phenyl-C61-butyric acid metbyl ester $\left(\mathrm{PC}{ }_{61} \mathrm{BM}\right)$ and phenyl-C61-butyric acid methyl ester $\left(\mathrm{PC}_{71} \mathrm{BM}\right)$ shown in Figure 2.5 together with some of the studied conjugated polymers poly [2,3-bis-(3-octyloxyphenyl)quinoxaline-5,8-diyl-altthiophene-2,5-diyl] (TQ1), poly[indacenodithieno[3,2-b]thiophene-alt-6-(2-ethylhexyl)-4,8$[1,2,5]$ thiadiazolo [3,4-f]isoindole-5,7-dione] (P21) and poly [N,N'-bis(2-bexyldecyl)isoindigo-6,6'diyl-alt-thiophene-2,5-diyl] (P3TI).

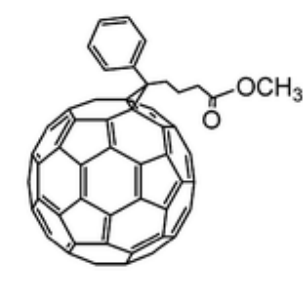

$\mathrm{PC}_{61} \mathrm{BM}$

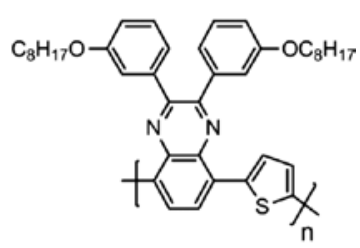

TQ1

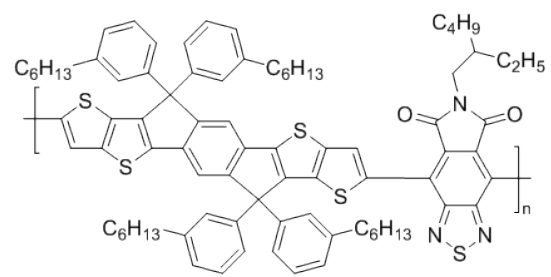

P21

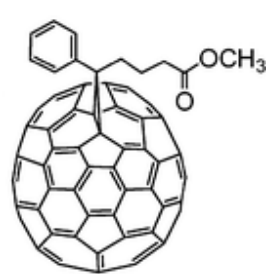

$\mathrm{PC}_{71} \mathrm{BM}$

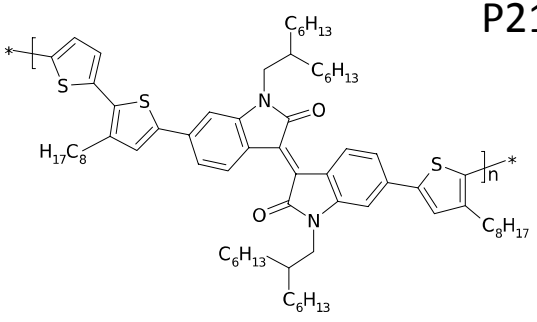

P3TI

Figure 2.5 Molecular structures of the fullerene derivatives and some of the conjugated polymers used in the active layers in the work contained in this thesis. 


\section{Chapter 3}

\section{Polymer solar cells}

A solar cell is a device that directly converts light energy in to electrical energy. The simplest construction is a semiconductor sandwiched between two conductive electrodes, of which at least one is transparent. Upon illumination light is absorbed by the semiconductor if $E_{P}>E_{g}$ and an exciton is created. The exciton is then split into free charges that are collected at the electrodes. The electrodes must be selective and only allow electrons to leave the semiconductor at the cathode and only holes at the anode. Thus, a potential difference (photovoltage) is generated and electrical work can be performed by the generated photocurrent over a load in an external circuit. A comprehensive introduction to the fundamental physics of solar cells is given in reference [4].

The driving force for research within polymer solar cells is mainly the possibility for low-cost solar energy conversion using organic materials processable from solution. This enables high speed roll to roll (R2R) printing and coating methods for production [15] that could potentially facilitate truly low cost solar cells [16,17]. The layers needed for power conversion is $\sim 100-500 \mathrm{~nm}$, which is why also the energy payback times are potentially as short as a few months [18]. However, before realization of these potentials much work on the optimization and understanding of this type of solar cells remains, whereof some will be discussed more in detail in this thesis.

a)

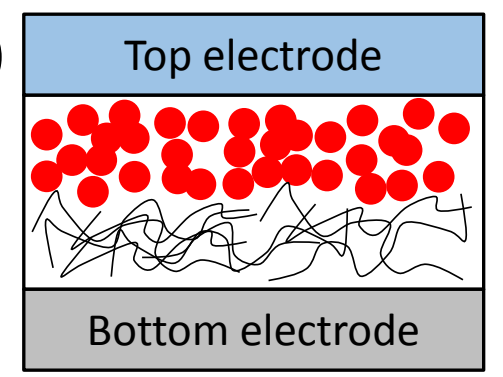

b)

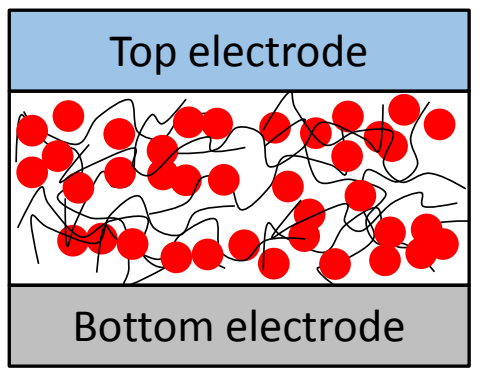

Figure 3.1 (a) Bilayer and (b) bulk heterojunction active layer cross sections showing fullerenes in red and polymers in black. 


\section{OPV history}

The first polymer solar cell had a polyacetylene active layer and had a very poor performance [19] due to the high exciton binding energy in organics. The solution to this problem, and consequently the first decent performing OPV, was the introduction of a bilayer [20] shown in Figure 3.1a, where the electron is transferred to a material with higher electron affinity at the bilayer interface. The electron donating material is commonly referred to as the donor and the electron accepting as the acceptor. Thus, a charge transfer (CT) exciton is generated with the electron on the acceptor and the hole on the donor molecule and the binding energy of the CT exciton is now low enough for dissociation into free charges at room temperature.

Still, the performance of bilayers is severely limited by the $\sim 10 \mathrm{~nm}$ diffusion length of the exciton [21] in the pure donor and acceptor layers, that in turn limits the thickness of the layers and so also the light absorption. Albeit being strong absorbers, $\sim 10 \mathrm{~nm}$ thick conjugated polymer layers are far from enough to absorb a large fraction of the incident light.

In 1995 the bulk heterojunction (BHJ) was introduced for a polymer:polymer blend [22] and a polymer:fullerene blend [23], where the both materials are finely intermixed in the same layer, illustrated in Figure 3.1b. The BHJ is also the structure of the active layers for the most efficient devices today, where the main focus has been on the polymer:PCBM blends as they have shown the highest efficiencies.

\section{Solar cell characterization}

For reproducible characterization of solar cells at any time and place over the world, the sun is approximated with the solar spectrum AM1.5G, corresponding to an incidence angle of $48.2^{\circ}$ where the solar light passes the atmosphere 1.5 times the zenith atmosphere length. The absorption and scattering of the atmospheric gases ozone, water vapor, oxygen and carbon dioxide shown in Figure 1.1 reduces the solar irradiance at sea level. In Figure 3.2 the spectral irradiance at sea level for AM1.5G is shown. The full spectrum extends over $4000 \mathrm{~nm}$ and has a spectrally integrated irradiance of $1000 \mathrm{~W} / \mathrm{m}^{2}$. 


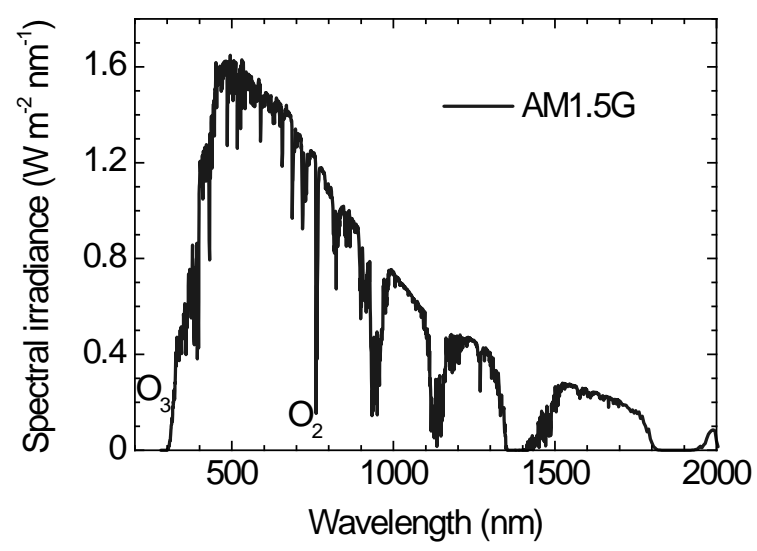

Figure 3.2 AM1.5G solar spectrum

\section{JV-characteristics}

To characterize the performance of solar cells and determine their maximum power conversion efficiency $(P C E)$, the photo generated current density $(J)$ is measured as a function of applied voltages $(V)$. A typical $J V$-curve is shown in Figure 3.3 together with the power generated as a function of voltage $P(V)=J(V) * V$. The solar cell power conversion efficiency is determined from the maximum point on the power curve, $P_{M A X}$, where $P C E=P_{M A X} / P_{I N}$ and $P_{I N}$ commonly is the 1000 $\mathrm{W} / \mathrm{m}^{2}$ from AM1.5G.

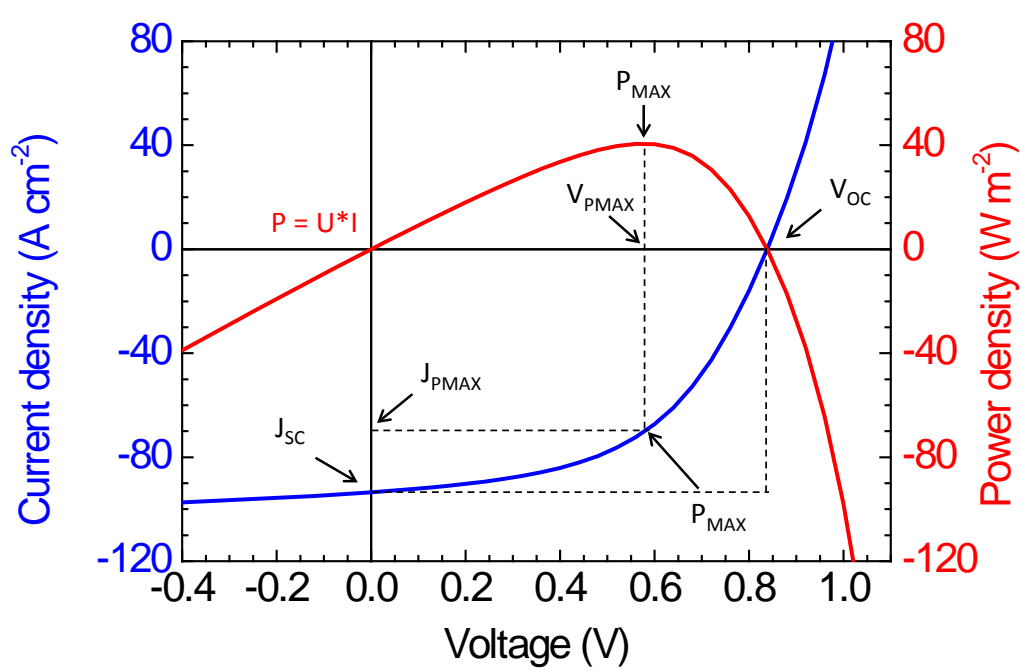

Figure 3.3 JV and PV characteristics for a typical organic solar cell with the figures of merit used for characterization illustrated.

Further information attainable from the $J V$-curve is the short circuit current density $J_{S C}$ measured at equipotential electrodes, the open circuit voltage $V_{O C}$ and the fill factor $F F$, defined as $F F=P_{M A X} / J_{S C} V_{O C}$. Thus the power conversion efficiency can be calculated from 


$$
P C E=\frac{P_{M A X}}{P_{I N}}=\frac{J_{S C} V_{O C} F F}{P_{I N}}
$$

In dark, solar cells are ideally diodes that conducts only in the forward direction and blocks all current at reverse bias. Thus the extracted current density $J$ is $J=J_{P h}-$ $J_{D A R K}$ where $J_{P h}$ is the photogenerated current density and $J_{D A R K}$ the dark current density (note the reverse sign of the current in Figure 3.3). Figure 3.4 shows the equivalent circuit diagram with the photocurrent source and the diode. Furthermore, two resistive elements are added, the series resistance $R_{S}$ and the parallel resistance $R_{P}$. Ideally $R_{S}$ is zero and $R_{P}$ infinite to avoid power losses. However, this is not always the case, especially not for thin film polymer solar cells where pinholes in the film may induce local shorts between the electrodes reducing $R_{P}$ and thus current is lost at forward bias reducing $F F$ while the diode is conducting also at reverse bias. The contributions to $R_{S}$ are internal resistances in the active layer, but also contact resistances at the active layer electrode interface and a limited conductivity of the electrodes. The effects of $R_{S}$ losses is mainly a reduced $F F$.

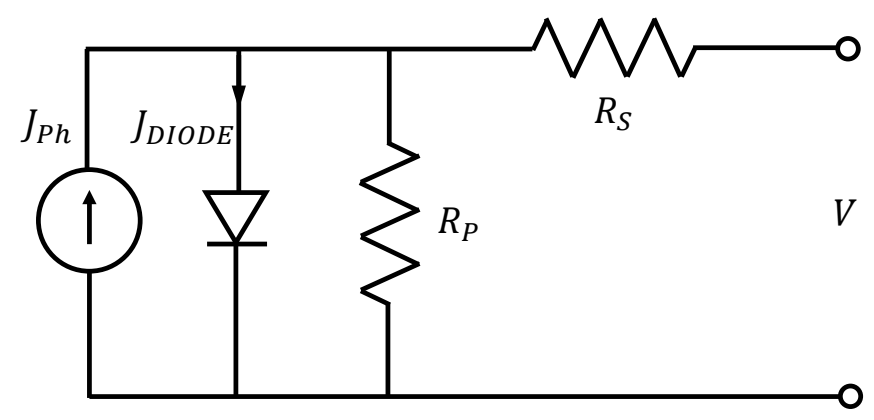

Figure 3.4 Equivalent circuit diagram at $\mathrm{V}_{\mathrm{OC}}$

\section{Theoretical conversion limit}

The incident photon flux from the sun can be recalculated to a potentially available photocurrent density that increases with a lower $E_{g}$ as materials with absorption far into the near infrared can absorb more photons. The cumulative photon flux density and corresponding photocurrent density available from AM1.5 are shown in Figure 3.5a. However, the bandgap also constitutes a limit for $V_{O C}$. The theoretical maximum PCE is attained from the product of the photocurrent and achievable voltage. The full derivation, also including $F F$, was first done by Shockley and Queisser using detailed balance [24] and shows a $P C E$ peak of $33.7 \%$ for $E_{g}=$ $1.4 \mathrm{eV}$. However, the record efficiencies under AM1.5G illumination are $28.8 \%$ for a solar cell based on gallium arsenide and $25.6 \%$ for a silicon single junction solar cell [25]. The best OPV devices have a PCE of $11 \%$ and $9.7 \%$ [25] for single lab cell and minimodules respectively. 


\section{External quantum efficiency}

From the external quantum efficiency $(E Q E)$ the spectral ratio of extracted electrons to the number of incident photons $N_{p h}(\lambda)$ are calculated

$$
\operatorname{EQE}(\lambda)=\frac{N_{e}(\lambda)}{N_{p h}(\lambda)}
$$

from the electron flux density $N_{e}(\lambda)$ and photon flux density $N_{e}(\lambda)$.
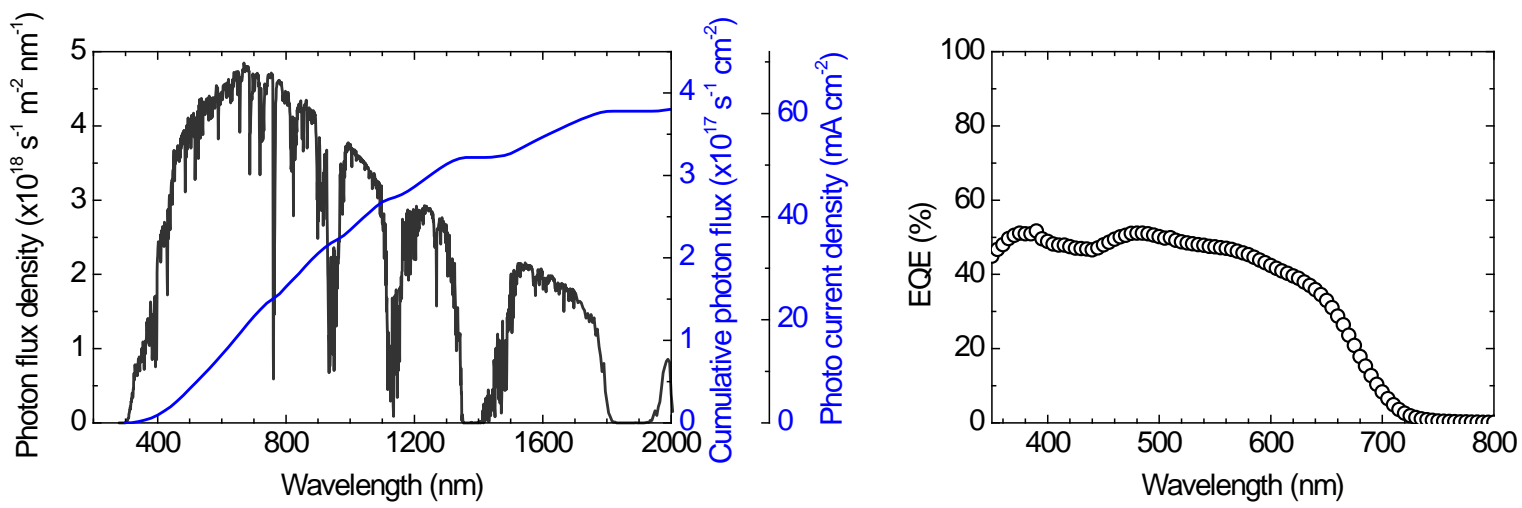

Figure 3.5 (a) AM1.5 photon flux density and the cumulative photon flux density and the corresponding photocurrent density. (b) EQE spectrum for a polymer solar cell with TQ1:PC ${ }_{71} B M$ active layer.

$E Q E$ is usually measured at short circuit conditions and $N_{e}(\lambda)$ is calculated from

$$
N_{e}(\lambda)=\frac{J_{S C}(\lambda)}{q}
$$

where $q$ is the elementary charge, but can be determined from any $J(V)$. The incident photon flux density is calculated from the spectral irradiance $I(\lambda)$ as

$$
N_{p h}(\lambda)=\frac{I(\lambda)}{E_{P}(\lambda)}
$$

An $E Q E$ spectra for a TQ1:PC ${ }_{71} \mathrm{BM}$ polymer solar cell is shown in Figure 3.5b illustrating that the solar cell is far from optimized. For maximum performance all photons are absorbed, converted to electrons and extracted from the solar cell. Thus, losses can be divided in to optical or electric;

$$
E Q E=A * I Q E
$$

where $(A)$ is the absorptance of the solar cell and $I Q E$ the extraction efficiency of excited electrons. For bulk solar cells $A=1-R$, where $R$ is the reflectance of the device. However for thin film polymer solar cells there are additional optical losses. 
These will be discussed more in detail in Chapter 4 while the electrical losses limiting $I Q E$ will be discussed in the coming sections.

\section{$\mathrm{BHJ}$ principle of operation}

The principle of operation for an organic BHJ solar cell is described if Figure 3.6. In a simplified scheme the steps from photon absorption to charge collection at the electrodes are described by:

1 Exciton generation upon photon absorption

2 Exciton diffusion to a donor:acceptor interface

3 Exciton dissociation and charge transfer

4 Dissociation of the CT exciton

5 Charge transport to the electrodes

6 Charge collection at the electrodes
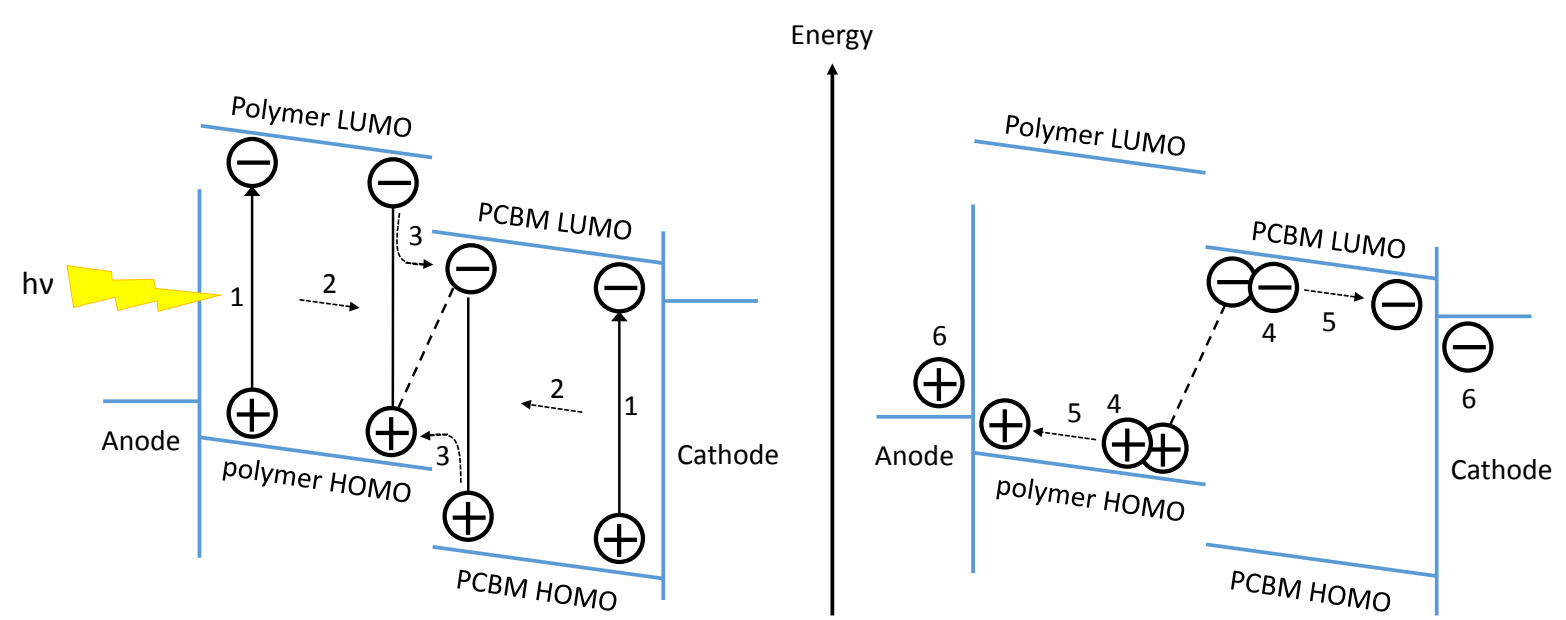

Figure 3.6. Schematic working principle of a $\mathrm{BHJ}$ polymer solar cell.

\section{Exciton diffusion and dissociation}

For efficient exciton dissociation the domain size of the absorber must be smaller than the exciton diffusion length of $\sim 10 \mathrm{~nm}$ [21]. For dissociation of the donor exciton an energetic offset driving force corresponding to $\Delta E=\mathrm{LUMO}_{\text {DONOR }}-\mathrm{LUMO}_{\mathrm{ACCEPTOR}}$ of at least $0.3 \mathrm{eV}$ [26] is needed. This has been the view in the field for some time, however a different way to define the driving force is to compare the optical bandgap of the donor with the energy of the charge transfer state determined from subbandgap $E Q E$ measurements [27]. Using this definition an offset of $\Delta E \sim 0.1 \mathrm{eV}$ was enough for efficient exciton dissociation [28]. 
The energy of the donor and the CT states are illustrated in the Jablonski diagram in Figure 3.7. The polymer HOMO is the common ground state and the energy loss $\Delta E=E_{g}-E_{C T} . E_{g}$ is the optical bandgap of the polymer and $E_{C T}$ the charge transfer state energy.

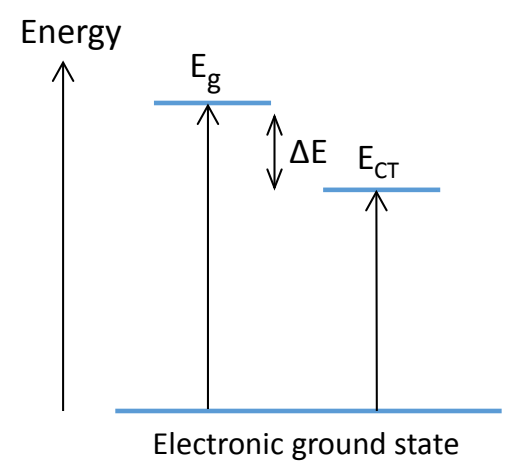

Figure 3.7 Jablonski diagram showing the offset between donor and CT excited states and the common ground state.

The open circuit voltage in polymer solar cells is proportional to the HOMO-LUMO difference and has empirically been shown to be $q V_{O C}=E_{C T}-0.6 \mathrm{eV}$ [29]. Thus the total potential loss $E_{g}-q V_{O C}=\Delta E+0.6 \mathrm{eV}$. For the future, this is an important topic, as a reduction of this potential loss would take the accessible conversion efficiencies of polymer solar cells closer to the levels of the inorganic counterparts.

\section{Charge transport and collection}

The charge carrier transport efficiency is a competition between collection at the electrodes and recombination within the device. The transport is limited by the charge carrier drift length $l$ that is a product of the charge carrier lifetime $\tau$ and the charge carrier velocity $v$. The drift length must be larger than the distance from the excitation in the device to the electrodes for the charges to be collected. $v$ is determined by the product of the material specific charge carrier mobility $\mu$ and the electric field $E$ over the device which leads to the drift length dependence

$$
l=\mu \tau E
$$

Organic semiconductors have generally low mobilities and limited lifetimes. The voltage over the junction is proportional to the work function difference of the electrodes, and the internal electrical field inversely dependent on the distance. For a device with ohmic contacts the internal field is proportional to the HOMODONOR $\mathrm{LUMO}_{\text {ACCEPTOR }}$ difference.

Accordingly, a thinner active layer has a higher internal electric field resulting in an increased drift length, while also the needed drift length is reduced for thinner layers. 
At $P_{M A X}$ the field over the device is reduced, which hampers the drift transport. Thus, the $\mu \tau$ product must be high enough to facilitate charge transport also under lower applied fields. In summary, thinner active layers are beneficial for charge transport and the optimal active layer thickness is commonly around $80-100 \mathrm{~nm}$. However, a limited number of polymer:PCBM blends displays a high $F F$ also for $200+$ nm thick active layers [30].

\section{Recombination}

Electrical losses implies that photoexcited charges are not collected at the anode. Thus they have relaxed, or recombined, within the device. The extracted photo current at steady-state equals the generated carriers minus the recombined as

$$
J=q(G-R)
$$

where $q$ is the elementary charge, $G$ the generation rate and $R$ the recombination rate. $G=A I$ where $A$ is the absorptance in the active layer and $I$ the illumination intensity. Thus, $G$ is linearly proportional to the photon flux. $R$ on the other hand is proportional to the charge carrier density $n$ in the device as $R=\beta n^{\gamma}$, where $\beta$ is the recombination constant and $\gamma$ the order of recombination.

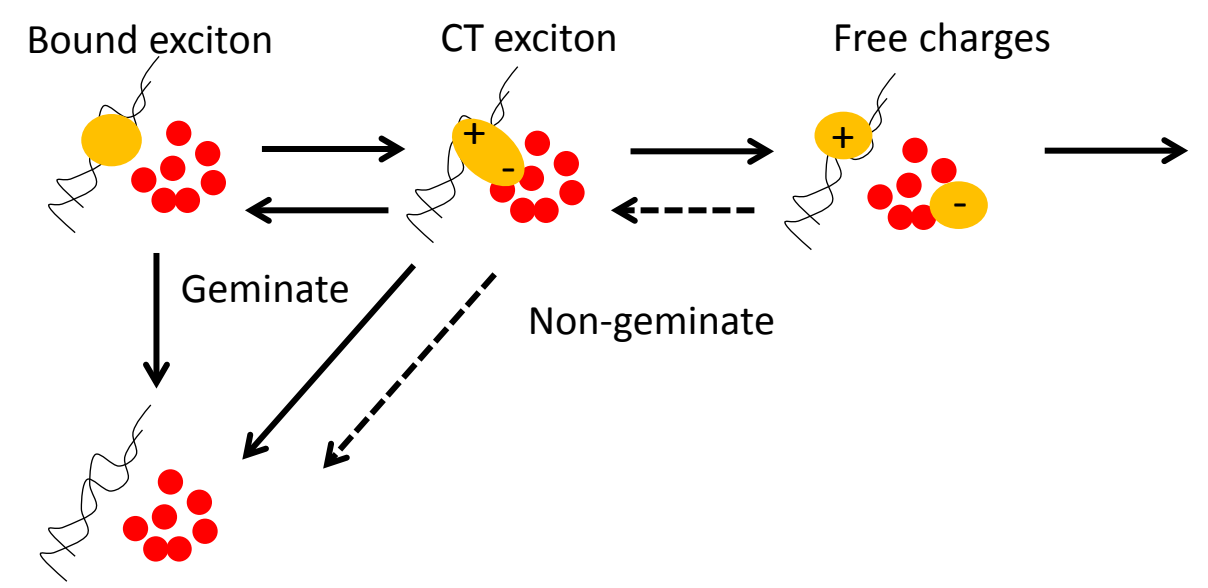

Figure 3.8 Geminate and non-geminate recombination pathways. Non-geminate recombination is described by the dashed arrows.

Recombination is divided in two main categories, geminate and non-geminate, illustrated in Figure 3.8. Geminate recombination is the recombination of an electron and a hole created by the same photon. Accordingly recombination between an electron and a hole created by different photons are non-geminate.

Recombination of the bound excitons and of un-split CT excitons are by definition geminate. This is a first order process, $\gamma=1$, as $R$ is proportional to the number of 
excitons in the device and thus is proportional to the illumination intensity and the dissociation rate of excitons.

Non-geminate recombination involves free charge carriers. Bimolecular recombination is the recombination between two free charge carriers, a hole and an electron, and it occurs by definition at the donor:acceptor interface via the CT-state. Upon photoexcitation one hole and one electron is created, thus the number of holes equals the number of electrons. Therefore, bimolecular recombination is a second order process as it is proportional to the product of the number of electrons and holes; $R_{\text {BIMOLECULAR }} \propto n p=n^{2} \propto I^{2}$, where $n$ and $p$ are the electron and hole charge carrier densities and $\gamma=2$. Bimolecular recombination is believed to be the dominant recombination channel for well performing solar cells [31] and is consequently an important parameter to determine for polymer solar cells.

Other recombination pathways are trap recombination that is a first order process, where one free charge carrier recombines with a trapped carrier stuck deep down in the density of states. A high share of dark (not photoexcited) back ground carriers also leads to a first order dependence of the recombination as the photoexcited carriers recombine with light intensity independent carriers.

Surface recombination, or rather diffusion driven charges being collected at the "wrong" electrode due to a non-selective contact, generates a current opposite to the drift photocurrent, and is thus not really a recombination. However, it reduces the collected photocurrent in a similar manner as recombination.

\section{Device geometry}

Organic solar cells are produced as thin film stacks with the active layer sandwiched between two electrodes. The electrode configuration comes in a vast variety of materials and orders of the layers. The most common laboratory geometry is shown in Figure 3.9a and comprise a glass substrate with a $\sim 150 \mathrm{~nm}$ thick sputtered layer of indium tin oxide (ITO). On top of the ITO the conductive polymer PEDOT:PSS and the active layer is coated from solution. Finally the cathode composed of a few $\AA$ lithium fluoride (LiF) or calcium (Ca) and a $100 \mathrm{~nm}$ thick aluminum layer are thermally evaporated on top of the active layer, where the $\mathrm{LiF}$ and $\mathrm{Ca}$ act as a protective layer hindering aluminum atoms from diffusing in to the active layer [32].

This laboratory stack is not compatible with large scale low cost production as ITO contains the scarce indium and if used in a module would constitute $40-50 \%$ of the total materials cost [33].

The solution processable conductive polymer PEDOT:PSS is used to replace the ITO in the reversed geometry shown in Figure 3.9b. This stack is also preferable for large scale printing, where the active layer and top transparent electrode can be 


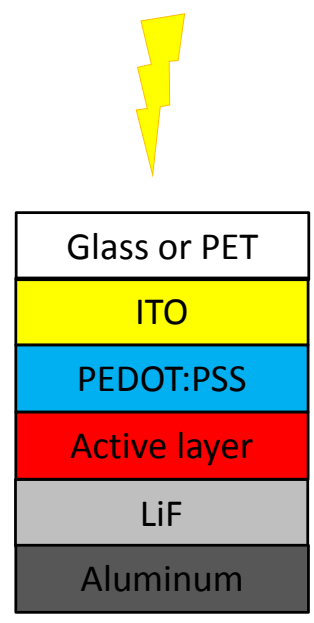

Standard

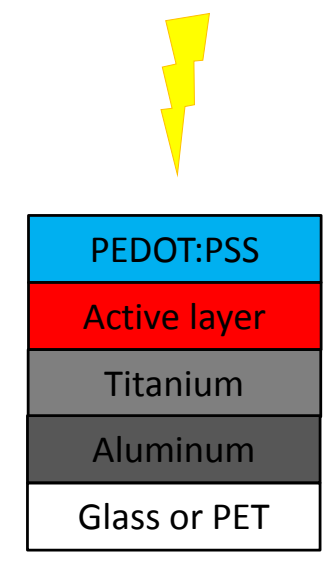

Reversed

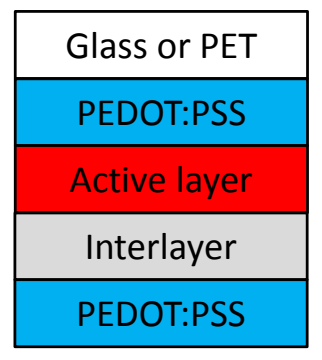

Semitransparent

Figure 3.9 Cross sections of standard, reversed and semitransparent solar cell stacks

coated on a premetallized substrate. A thin titanium or chromium layer is commonly used to protect the aluminum from oxidation, which enhances the device stability. However, the energy input using sputtering for metal deposition is large [18], which is why an all $\mathrm{R} 2 \mathrm{R}$ coating compatible geometry is to prefer. An example with two solution processable PEDOT:PSS electrodes is shown in Figure 3.1c. The high work function of pristine PEDOT:PSS allows for efficient hole extraction from the photoactive layer, while modification of the second PEDOT:PSS with a conjugated polymer or polyelectrolyte layer lowers the PEDOT work function for electron extraction. This way the solar cell can also be made semitransparent which could be interesting for greenhouses [34] and as combined solar screening and power generators in facades.

\section{Improving PCE}

The strategy to improve the power conversion efficiency in polymer solar cells has mainly been by synthesizing new polymers with sought after properties such as improved mobility, tuned energetic alignment with PCBM, a reduced bandgap, enhanced solubility and degree of crystallinity. Hence, a constant flow of new polymers enters the field for characterization. Many do not pass the first screening due to low performance, but yet there in an almost infinite amount of designs and geometries for conjugated molecules. Progress has been made in predicting the absorption coefficient of conjugated molecules and polymers from quantum chemical calculations [35]. A predictive calculation method would save much time spent on polymer synthesis. However, until a high correlation between calculated and experimental absorption strength is reached the polymers have to be synthesized and characterized. 


\section{Chapter 4}

\section{Optical modelling}

To predict the potential of novel conjugated polymers as solar cell absorbers their optical response must be determined. This has been done by reflectance mode spectroscopic ellipsometry.

\section{Spectroscopic ellipsometry}

Spectroscopic ellipsometry is regularly used for thin film material characterization by measuring the changes in polarization of light reflected from a sample under investigation [8]. The coordinate system for reflection of light at a plane boundary is defined according to the Fresnel convention [36] in Figure 4.1 where the light is propagating in the direction of the wave vector $\mathbf{k}$. The electric field $\mathbf{E}$ is decomposed into two components, one perpendicular to, and one parallel to the plane of incidence. These are referred to as the s- and p-polarizations from the German senkrecht and parallel that translates to perpendicular and parallel.

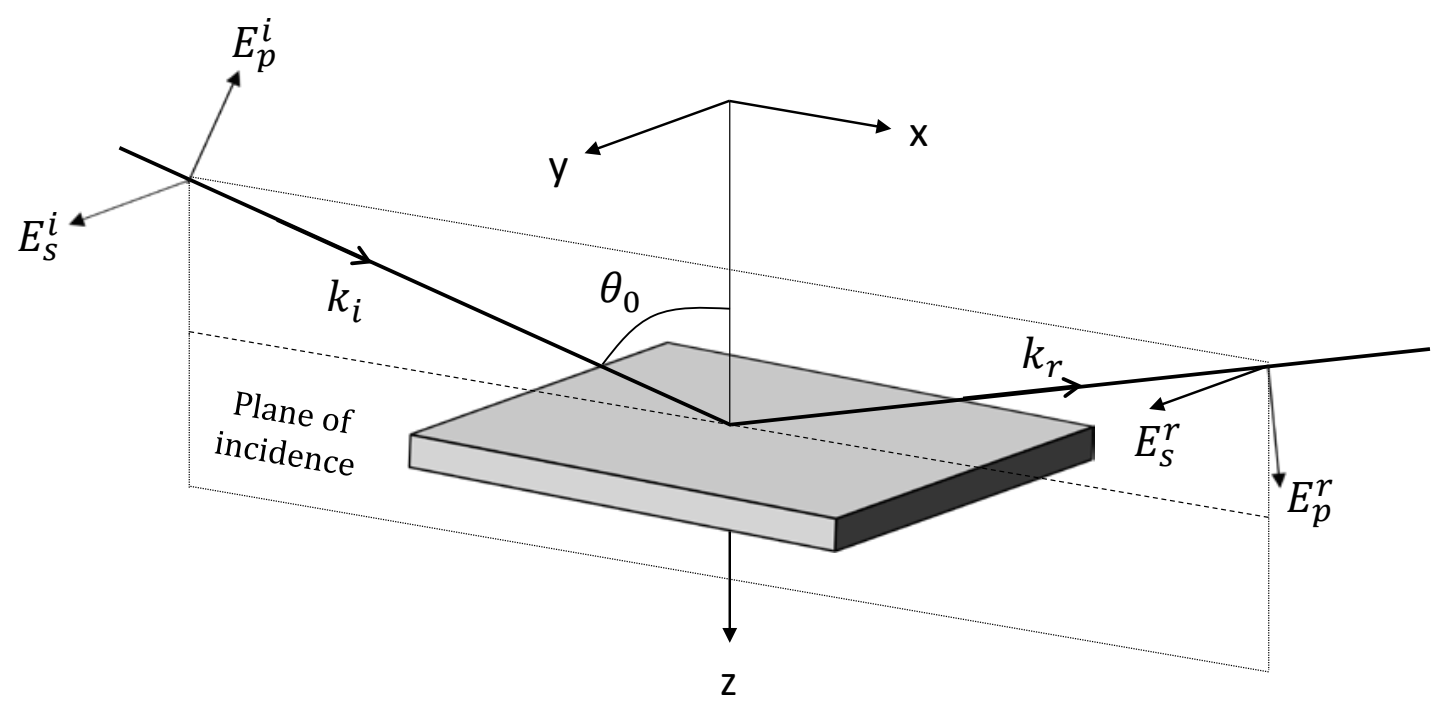

Figure 4.1 Reflectance at a plane boundary and definition of s- and p-polarization of the electric field vectors 
The polarization state is defined by $\chi$, which is the ratio of the $\mathrm{p}$ - and s-polarized electric field amplitudes for the incident and reflected light, respectively, according to

$$
\chi_{i}=\frac{E_{p}^{i}}{E_{s}^{i}} \quad \chi_{r}=\frac{E_{p}^{r}}{E_{s}^{r}}
$$

The reflectance of light at a surface is described by the reflection coefficients relating the incident and reflected electric field amplitudes as

$$
r_{p}=\frac{E_{p}^{r}}{E_{p}^{i}} \quad \text { and } \quad r_{s}=\frac{E_{s}^{r}}{E_{s}^{i}}
$$

The basic principles of the dual-rotating compensator ellipsometer (RC2 from J.A. Woollam Co., Inc.) used in the studies in this thesis is described in Figure 4.2. In this type of instrument the light from an unpolarized white light source passes through a polarizer and a compensator that constitutes the polarization state generator that sets the polarization of the light incident to the sample. The light reflected from the sample is passed through a polarization state analyzer, a second compensator and second polarizer (called analyzer), after which the light reaches the detector comprising a grating and a detector array to acquire spectral resolution. The two compensators rotate at angular frequencies with a ratio of 5:3 leading to that the measured signal at the detector can be decomposed as a Fourier series from which the full Mueller matrix [37] of the sample can be acquired.

Light source

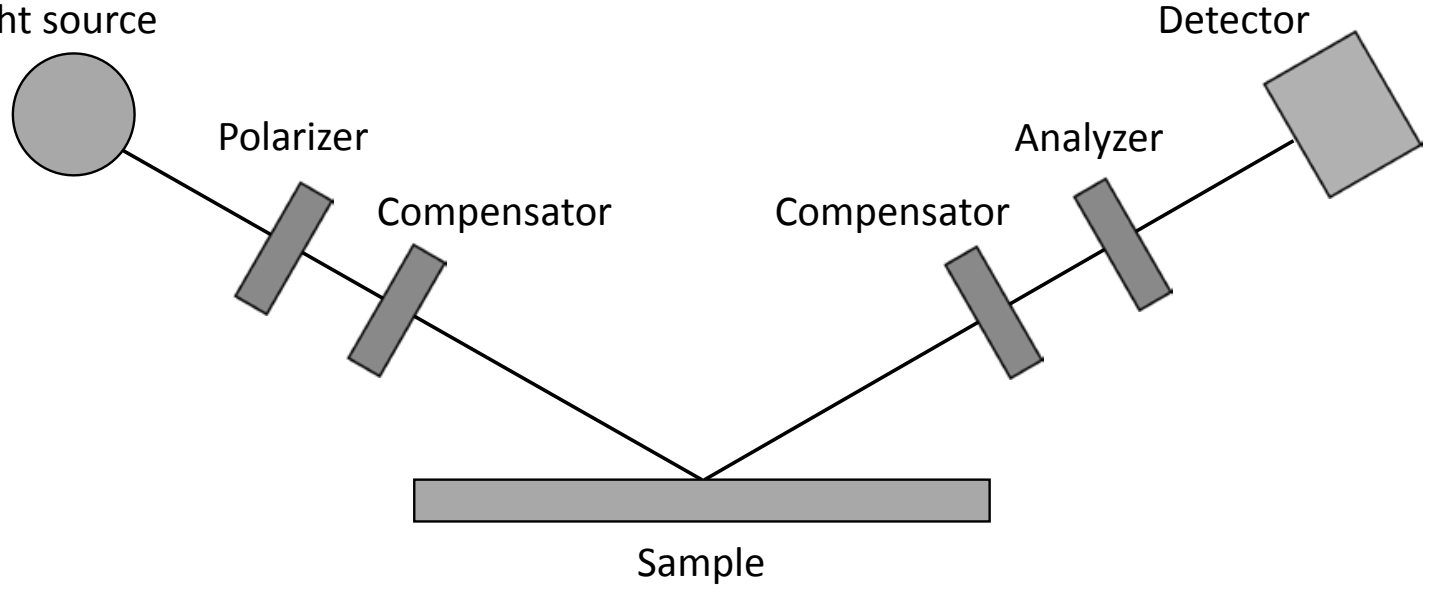

Figure 4.2 Schematic illustration of a dual-compensator ellipsometer

All samples studied in this work are isotropic or uniaxially anisotropic with the optical axis parallel to the surface normal. For this purpose the standard ellipsometric angles $\Psi$ and $\Delta$ fully describe the sample, and can be calculated from the Fourier coefficients. In standard ellipsometry the measured quantity $\rho$ is the ratio between the polarization state of the incident and the reflected light according to [8] 


$$
\rho=\frac{\chi_{r}}{\chi_{i}}
$$

Thus, $\rho$ can be expressed as

$$
\rho=\frac{E_{p}^{r}}{E_{s}^{r}} \frac{E_{s}^{i}}{E_{p}^{i}}=\frac{r_{p}}{r_{s}}=\tan (\Psi) e^{i \Delta}
$$

To determine the optical constants $n$ and $k$ from the ellipsometric angles a model is created to describe the sample and the model calculated $\Psi_{\text {mod }}$ and $\Delta_{\text {mod }}$ are fitted to the experimentally determined $\Psi_{\text {exp }}$ and $\Delta_{\text {exp }}$. A flow chart for the fitting procedure is shown in Figure 4.3.
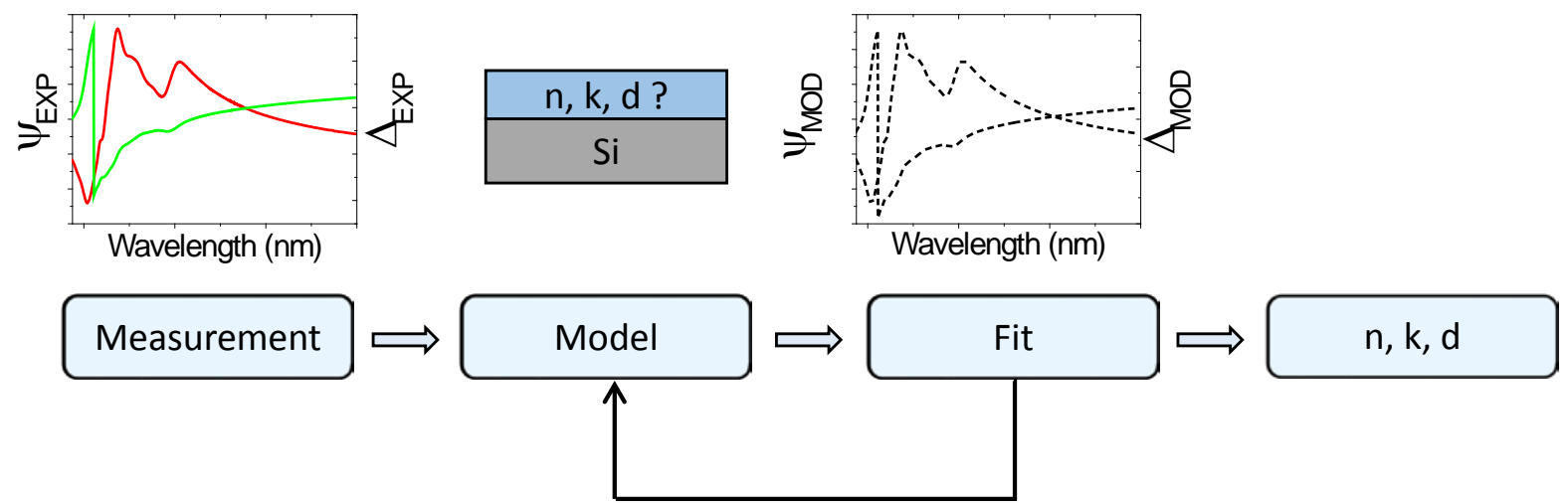

Figure 4.3 Flow chart for the ellipsometry analysis

The unknown parameters of the polymer film is $n, k$ and the film thickness $d$. Thus the two experimental quantities $\Psi$ and $\Delta$ and three unknowns generates an underdetermined equation system. However, multiple incidence angle measurements together with utilization of the spectral range below the bandgap where $k=0$, instead over-determines the equation system. Hence, $d$ and $n$ are modelled in the spectral range below the bandgap using the Cauchy dispersion model

$$
n(\lambda)=A+\frac{B}{\lambda^{2}}+\frac{C}{\lambda^{4}}
$$

where $A, B$ and $C$ are fitting parameters. By locking $d$ the model can be stepwise expanded into the absorbing range using a Kramers-Kronig consistent B-spline model [38]. However, the B-spline node separation may give false signatures and a conversion of the model to an oscillator model may be needed for stability.

For accurate determination of the optical constants multi-sample analysis of samples with different thicknesses can be performed [39]. However, polymer and polymer:fullerene samples with different thickness will experience different drying kinetics and may reach different conformational states affecting the conjugation 
length and therefore different optical constants. Thus, the measurement should ideally be performed under identical conditions as for solar cell preparation.

To gain confidence of the fits the modelled $k$ is matched against the absorption coefficient as determined by spectrophotometry using the Beer-Lamberts law. For further validation also an effective medium approximation (EMA) can be used, where the refractive index of the blend is calculated from the pure materials.

The commonly used Bruggeman EMA model [40] calculates the effective $\varepsilon$ from blends of material $\mathrm{A}$ and $\mathrm{B}$ with volume fractions $f_{A}$ and $f_{B}$ and the corresponding $\varepsilon_{A}$ and $\varepsilon_{B}$ from

$$
f_{A} \frac{\varepsilon_{A}-\varepsilon}{\varepsilon_{A}+2 \varepsilon}+\left(1-f_{A}\right) \frac{\varepsilon_{B}-\varepsilon}{\varepsilon_{B}+2 \varepsilon}=0
$$

However, the EMA model assumes a blend of the materials with pure phases that must not be too small, as they should have their individual dielectric properties, while the phases must be sufficiently smaller than the wavelength of light to avoid scattering. The second criterion is fulfilled for all well performing blends, but the first may induce a violation. Polymer:fullerene blends have previously been shown not to fulfill the criterions for EMA [41], nor does the EMA and measured optical constants match perfectly in a recent study on amorphous polymer:fullene blends [42]. However, the agreement is generally good enough for a plausibility control.

The discrepancy between EMA models and the measured blend optical constants are mainly due to changes of the geometry of both the conjugated polymer and the PCBM molecules in a blend film, compared to the pure films [42]. The absorption of PCBM has been observed to increase with the PCBM load when dispersed in a polystyrene host matrix [43]. Further studies have shown an enhanced absorption of PCBM in films as compared to being dispersed in solutions. The same study also showed that an increased PCBM fraction in blends with a conjugated polymer enhance the PCBM absorption due to aggregation [44].

Besides, many conjugated polymers display a preferential orientation of the backbone along the substrate surface leading to an uniaxial anisotropic film with higher refractive index and extinction coefficient in the ordinary (in-plane) direction as compared to the extra-ordinary (out-of-plane) direction parallel to the surface normal [45]. The anisotropy is partially or completely broken into an isotropic film upon mixing with fullerenes for many polymer:PCBM material systems [42]. 
The extinction coefficients for some high performing polymer:PCBM blends determined by spectroscopic ellipsometry are shown in Figure 4.4a. Figure 4.4b shows the extinction coefficient for the electrode materials PEDOT:PSS, ITO, aluminum and titanium. As all electrode materials are to some extent absorbing and the organic solar cells are thin film stacks causing interference, optical simultions are necessary to determine the actual absorptance in the active layer.
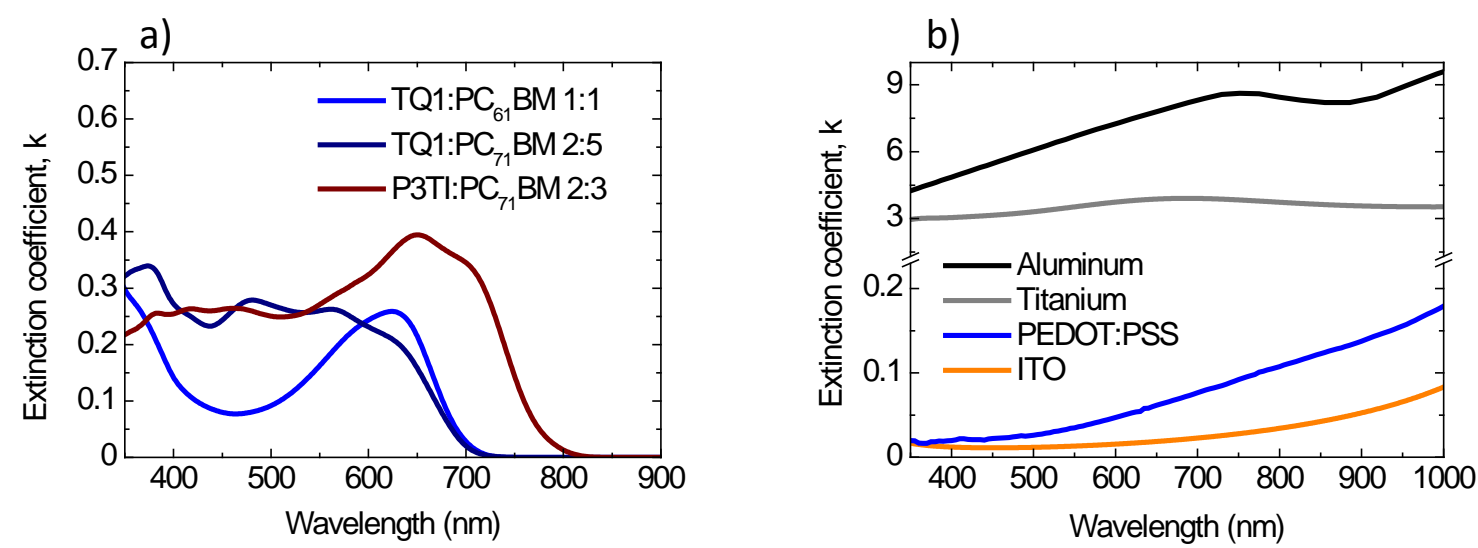

Figure 4.4 (a) Extinction coefficients for the active layers TQ1:PC ${ }_{61} \mathrm{BM} 1: 1$, TQ1:PC ${ }_{71} \mathrm{BM} 2: 5$ and P3TI:PCBM 2:3, ratios by weight. (b) Extinction coefficients for the electrode materials aluminum, titanium, PEDOT:PSS and ITO. 


\section{Optical simulations}

To evaluate the maximum performance of a novel material blend and to calculate $I Q E$ the absorptance of this active layer must be determined. The multilayer thin film stack geometry in organic solar cells with weakly absorbing transparent electrodes and highly reflective bottom electrodes induces parasitic electrode absorption. Further the light is coherent within the thin film stack giving rise to interference effects.

The Transfer Matrix Method (TMM) (Scattering Matrix Method) have been used successfully to calculate the optical power dissipation in thin film organic solar cells at normal [46] and oblique incidence [47]. The TMM model assumes that the incident monochromatic light can be described as plane waves and that all stack layers are homogenous with sharp boundaries perpendicular to the surface normal. Briefly the method uses the Fresnel reflection and transmission coefficients, $r$ and $t$, for s- and p-polarized light linking the incoming, reflected and refracted (transmitted) electrical field amplitudes at each interface

$$
r_{S(p)}=\frac{E_{S(p)}^{r}}{E_{S(p)}^{i}} \quad t_{s(p)}=\frac{E_{S(p)}^{t}}{E_{S(p)}^{i}}
$$

The electric field amplitude attenuation and phase shifts within each layer in the stack are considered and to determine the electric field as a function of the stack depth $z$, $\mathbf{E}(z)$ is separated into two waves, one propagating in the $+z$ direction and one in the $-z$ direction. From $\mathbf{E}(z)$ the optical power dissipation as a function of the stack depth $Q(z)$ is then calculated from Pointing's theorem $Q(z)=\left\langle-\nabla_{z} \cdot S\right\rangle$ for sand p-polarized monochromatic light according to

$$
Q^{s(p)}(z)=\frac{1}{2} c_{0} \varepsilon_{0} n \alpha\left|\mathbf{E}_{s(p)}(z)\right|^{2}
$$

Generally the thin film stack has an incoherent glass lid and the solutions for inclusion of that at oblique incidence are given in reference [48]. Integrating $Q(z)$ over a specific layer gives the optical power dissipated in that layer for the specific wavelength. The layer absorptance for broad band illumination is calculated from

$$
A_{j}(\lambda)=\frac{1}{S_{0}(\lambda)} \int_{\text {layer } j} Q(z, \lambda) d z
$$

where $S_{0}$ is the irradiance incident to the solar cell stack. From the active layer power dissipation also the maximum available photocurrent, $J_{\max }$, is calculated. Figure $4.5 \mathrm{a}$ shows $J_{\max }$ as a function of the active layer thickness for a solar cell stack with TQ1:PCBM and P3TI:PCBM active layers. Note the absorption maximum at $\sim 80$ $100 \mathrm{~nm}$ due to interference in the stack. To reach higher photocurrents a $200+\mathrm{nm}$ 
active layer is needed. Consequently the solar cells are commonly optimized around the first interference maxima in the active layer, due to the limited charge transport in organic semiconductors.

a)

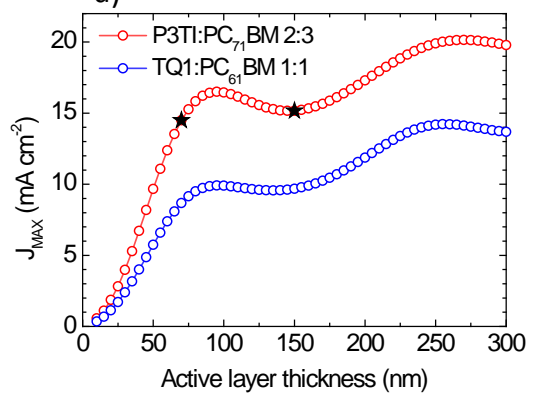

b)

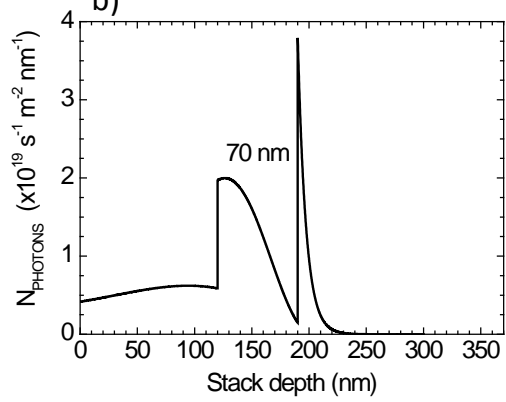

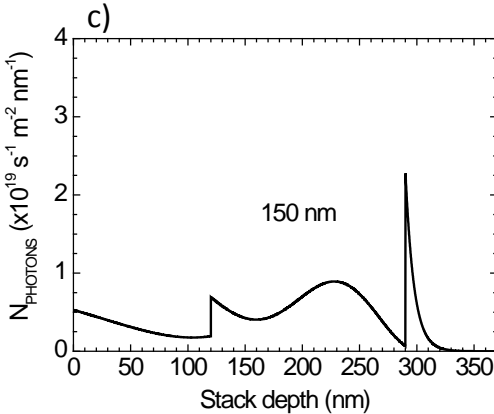

Figure 4.5 (a) Calculated $J_{\max }$ for a glass/PEDOT:PSS/Active layer/Aluminum stack with $-/ 120 / \mathrm{d} / 100 \mathrm{~nm}$ thick layers. (b-c) Spatial absorption profiles for $70 \mathrm{~nm}$ and $150 \mathrm{~nm}$ thick active layers

In Figure 4.5b and $\mathrm{c}$ the spatial absorption profiles and the absorbed photon flux in each layer are shown for the 70 and $150 \mathrm{~nm}$ thick P3TI:PCBM active layers. The absorption profiles have been used to correlate $F F$ with imbalanced hole and electron mobilities [49].

Furthermore the relative power distribution in each layer as a function of wavelength is shown in Figure 4.6a, where the relative losses are highlighted. In Figure 4.6b the spatial optical power dissipation is visualized as a function of $\lambda$ in $2 \mathrm{D}$ maps.
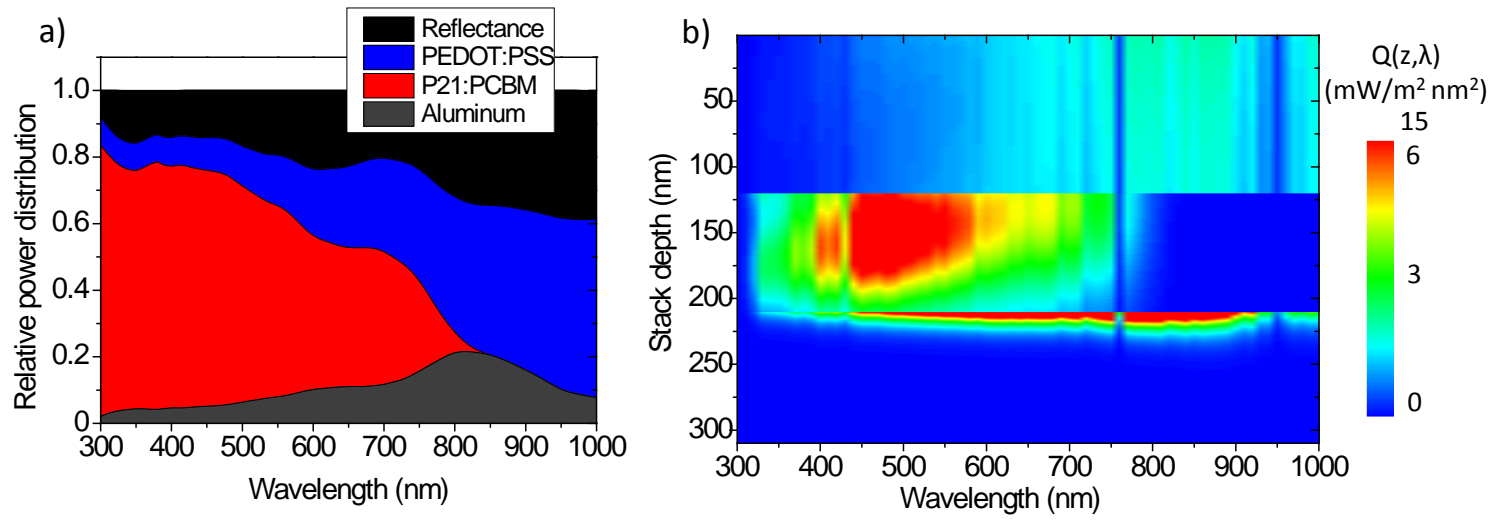

Figure 4.6 (a) Relative spectral power dissipation for a Glass/PEDOT:PSS/P21:PCBM/ Aluminum stack with $-/ 120 / 90 / 100 \mathrm{~nm}$ thick layers at $70^{\circ}$ incidence angle p-polarized light. (b) Spatially and spectrally resolved power dissipation for conditions in a for the p-polarized part of a non-polarized AM1.5G spectrum. 


\section{Calculating IQE}

The calculated active layer absorptance $A_{A C T I V E ~ L A Y E R}(\lambda)$ is used to determine IQE;

$$
\operatorname{IQE}(\lambda)=\frac{E Q E(\lambda)}{A_{A C T I V E ~ L A Y E R}(\lambda)}
$$

However, the solar cell stack comprise a number of thin films with thicknesses between a few nm up to a few hundred $\mathrm{nm}$. Precise thickness determination is challenging and the interfaces are not always perfectly sharp and all layers may not be perfectly homogenous. Thus, to verify the simulated IQE also the solar cell reflectance is measured and the stack layer thicknesses adjusted within the thickness error bars for a better match. The IQE can be deduced this way, for good fits between calculated and measured reflectance.

A perfect fit is not always reached [41] and for mismatches between the experimentally and modelled reflectance the $I Q E$ should be calculated according to

$$
\operatorname{IQE}(\lambda)=\frac{E Q E(\lambda)}{1-R(\lambda)-A_{\text {ELECTRODES }}(\lambda)}
$$

where $A_{\text {ELECTRODES }}$ is the parasitic electrode absorptance calculated by TMM and $R$ is the experimentally determined reflectance.

Previous studies have shown good agreement between spectrophotometric determination of $k$ together with a constant approximation $n=2$ for the active layer to calculate the parasitic electrode absorptance [50]. However, for the highest accuracy in $I Q E$, optical constants determined by ellipsometry combined with the experimentally determined solar cell reflectance should be used. In paper 1 we determine IQE of two lactam polymers, shown in Figure 4.7a, using optical constants determined by ellipsometry and experimentally measured reflectance. The experimental and TMM calculated reflectances are shown in Figure 4.7c.
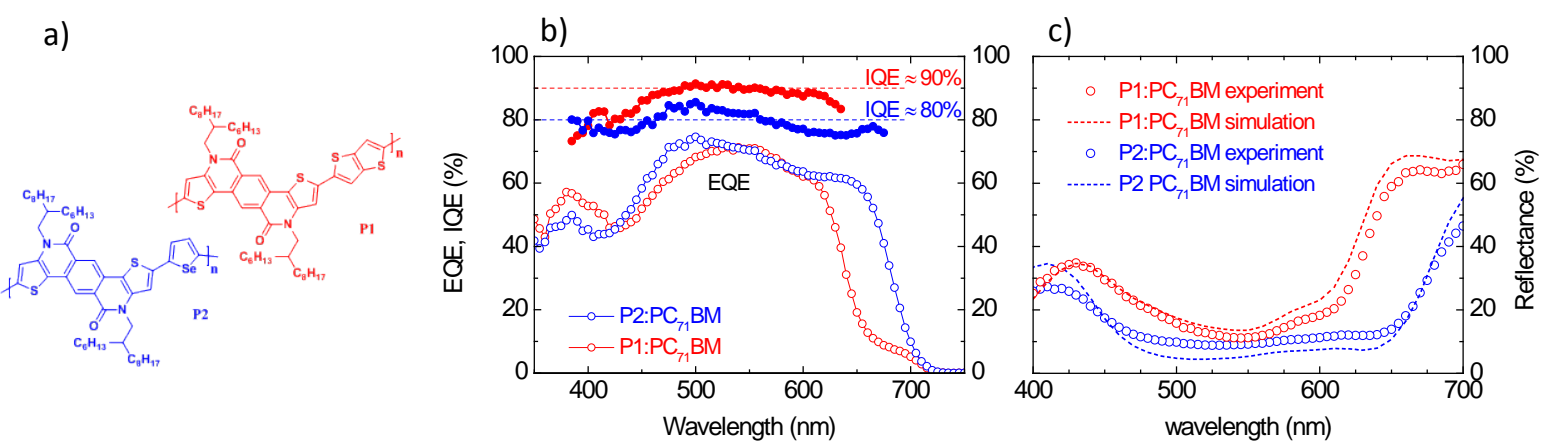

Figure 4.7 (a) Molecular structures for P1 and P2. (b) EQE and IQE for P1:PC ${ }_{71} \mathrm{BM}$ and P2 $\mathrm{PC}_{71} \mathrm{BM}$ (c) Simulated (dashed) and experimentally (o) measured reflectance for P1:PC $\mathrm{C}_{71} \mathrm{BM}$ and P2 $\mathrm{PC}_{71} \mathrm{BM}$. Adapted from Ref. [51] with permission from The Royal Society of Chemistry. 


\section{Anisotropy in PEDOT:PSS}

PEDOT:PSS is used as the electrode material for fully solution processable solar cells and also for R2R coating. The limited conductivity of PEDOT:PSS thin films limits the area of the solar cell due to resistive losses, but this can be compensated for by either making narrow solar cells or by printing thin current collectors of silver or carbon on top of the PEDOT:PSS [52-54]. As earlier mentioned, PEDOT:PSS can also be used for semi-transparent solar cells as the anode, but also as cathode by the addition of an electron selective interlayer [55].

Like many conjugated polymers PEDOT:PSS displays uniaxial anisotropy with its backbone oriented along the surface plane [56]. With the optical axis normal to the surface plane, the direction parallel to the plane is referred to as the ordinary direction (o) whereas the perpendicular is referred to as the extra ordinary (eo). Thus the inplane optical constants are $N_{o}=n_{o}+i k_{o}$ whereas the perpendicular are $N_{e o}=$ $n_{e o}+i k_{e o}$. The anisotropic optical constants for a high conductivity PEDOT:PSS film are shown in Figure 4.8.

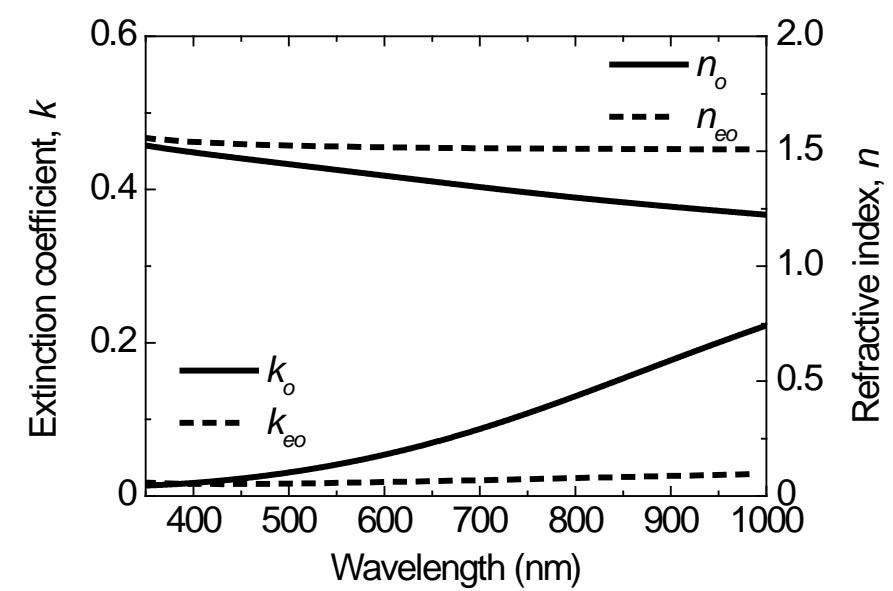

Figure 4.8 Ordinary and extra-ordinary refractive indices for a thin PEDOT:PSS film

The phenomenon with a directional dependence in $n$ is known as birefringence and in $k$ as dichroism. This implies that light incident to an anisotropic material will see different $N$ depending on its polarization state and angle of incidence. Accordingly the speed of light inside the anisotropic medium is direction dependent leading to light incident from an isotropic medium to an anisotropic medium experiences double refraction, where the transmitted wave is split in to two, propagating at different angles.

The reduced $k_{e o}$ leads to a reduced absorption strength in the extra ordinary direction implying a reduced parasitic absorption in PEDOT:PSS electrodes for light incident at oblique incidence and an increase of the transmission in semitransparent solar cells using PEDOT:PSS as both electrodes. Inclusion of anisotropy for 
calculation of the power dissipation in organic solar cells have previously been done for the active layer using the transmission line model [57].

In paper 2 we expand the commonly used TMM model by adopting the Fresnel reflection and transmission coefficients for an absorbing uniaxial media [58] to find the directions of wave and energy propagation within an absorbing anisotropic layer, to calculate the electric fields and power dissipation.

The effect of including anisotropy in the PEDOT:PSS layer gives a weak increase to the maximal photocurrent, $\sim 5 \%$ for reversed solar cells for non-polarized light at $75^{\circ}$ incidence angle relative to the surface normal. Semitransparent cells display an even lower enhancement upon including the anisotropy in both PEDOT:PSS electrodes, shown in $J_{p, \max }$ in Figure 4.9a. However, for p-polarized light at $70^{\circ}$ incidence angle internal interference together with a reduced electrode absorption yields a relative gain of up to $40 \%$ upon the inclusion of anisotropy for the active layer P3TI:PCBM deep down in the bandgap shown in Figure 4.9b. This is important as it may reduce the calculated parasitic losses in the PEDOT:PSS electrodes for active layers with strong absorption in the near infrared.
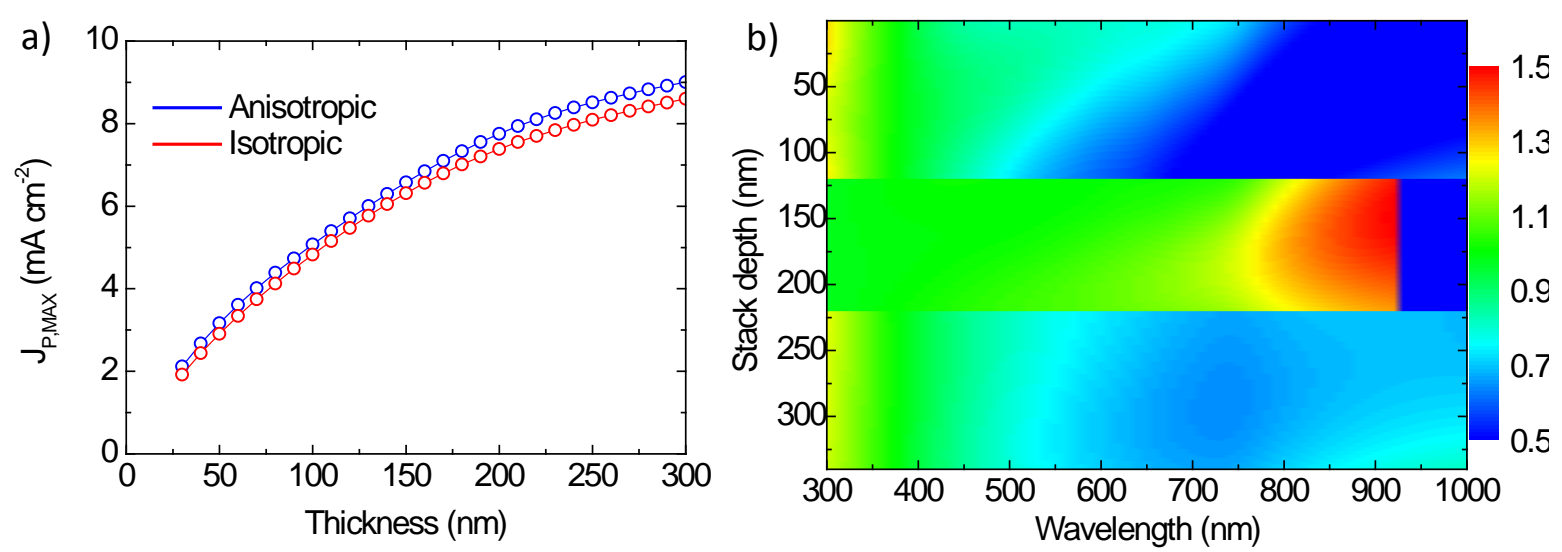

Figure 4.9 (a) $J_{p, \max }$ for an air/Glass/PEDOT:PSS/P3TI:PCBM/PEDOT:PSS/Glass solar cell stack with isotropic (red) and anisotropic (blue) treatment of the PEDOT:PSS layers for AM1.5G illumination at $70^{\circ}$ incidence angle. (b) The ratio for the spatial spectral power dissipation using anisotropic and isotropic description of PEDOT:PSS. 


\section{Chapter 5}

\section{Active layer morphology}

The active layer morphology is crucial for exciton dissociation and charge transport. For optimal performance the morphology in the active layer must consist of small enough domains to facilitate charge transfer, while still offer pathways of pure domains to the electrodes. The morphology has been thoroughly investigated for many material systems and the results are easiest accessible in the form of reviews $[59,60]$. A common view on an optimal morphology is a slight phase separation, preferably by aggregation or small scale crystallization, within the exciton diffusion limit of either component. Crystalline domains interconnected by high molecular weight polymers have also been suggested to be beneficial for efficient charge transport [61]. However, the optimal morphology depends highly on the specific material system.

The active layer is deposited from solution that commonly is a ternary blend composed of a solvent, the polymer and the fullerene. During the drying process the final morphology evolves and the kinetics during this process together with the solubility of the species determines the final morphology that may end up in a phase separated, finely intermixed or intermediate nanostructure. The final morphology are mainly determined by the solvent [62-64] or solvent blend [63,65], surface energy [64], temperature and drying kinetics [66,67].

\section{Morphology formation from solution}

Mixing of polymer blends and solutions in thermal equilibrium are described by the Flory-Huggins theory that calculates the Gibbs free energy of mixing, $\Delta G_{\text {mix }}$

$$
\Delta G_{m i x}=\Delta H_{m i x}-\mathrm{T} \Delta S_{m i x}
$$

where $\Delta H_{\text {mix }}$ and $\Delta S_{\text {mix }}$ are the changes in enthalpy and entropy respectively upon mixing and $T$ is the temperature [68]. $\Delta G_{\text {mix }}<0$ is the minimum criteria for mixing. Due to the very long chains that sterically hinders mixing, the entropy contribution for mixing from the polymer will be negligible, while the small molecule PCBM will have a positive contribution. $\Delta H_{m i x}$ is determined by the interaction energy by the 
blended materials upon contact and will be positive unless attractive forces between the different molecules are present. Thus for a polymer fullerene system the intermixing is determined by the balance between the fullerene phase contribution to $\Delta S_{\text {mix }}$ and the interaction energies. PCBM has been shown to be partly miscible in some conjugated polymers $[69,70]$. When cast from solution also $\Delta G_{\text {mix }}$ for the polymer and fullerene interactions with the solvents must be considered.

$\Delta G_{\text {mix }}$ displays three different regions, one stable with complete mixing, one unstable where infinitesimal diffusion driven concentration fluctuations initiate phase separation, known as the spinodal regime, and one metastable, binodal, regime where an energy barrier for phase separation leads to that higher concentrations fluctuations are needed to initiate phase separation.

Figure 5.1 shows the suggested pathways during drying for a solution with two solid components by Kouijzer et. al. [71]. For fast drying the initially well mixed blend can be frozen in to a finely intermixed morphology. However, the materials may also demix by liquid-liquid demixing or solid-liquid demixing. Liquid-liquid demixing have been shown to occur for many material blends, especially for higher PCBM loads, where the PCBM is driven out of the mixed domains via "negative" diffusion to form PCBM rich domains that grow with time [71]. Thus, slower drying results in larger phase separated polymer and PCBM rich domains [67]. However, liquid-liquid demixing does not occur for all polymer:PCBM blends and it has also been shown that an even slower drying reduces the purity of the liquid-liquid phase separated domains [72].

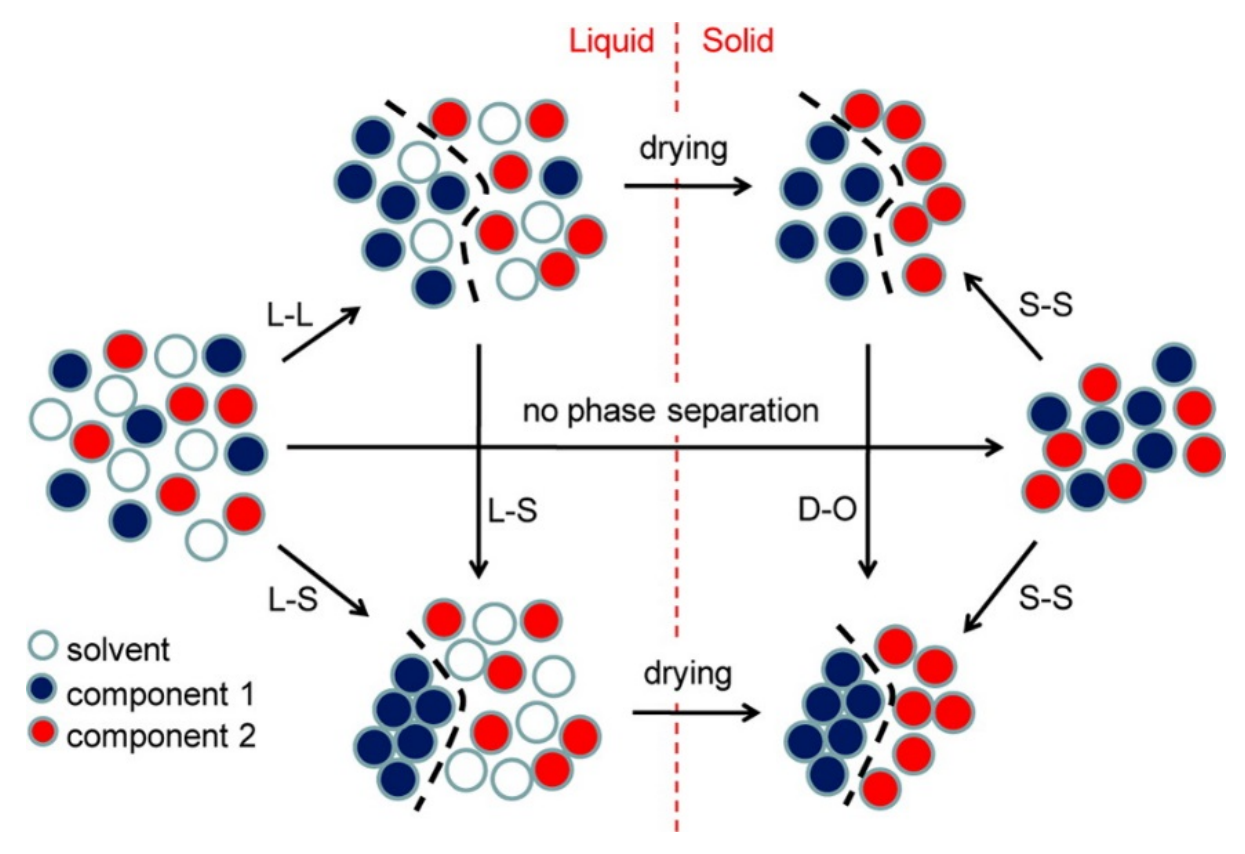

Figure 5.1 Schematic of the possible evolution of the morphology as described in reference "Reprinted with permission from J.Am.Chem.Soc.2013, 135, 12057-12067. Copyright 2013 American Chemical Society." [71] 
For a slower drying process the blend can also demix due to aggregation of either component as the concentration passes the solubility limit for either component. This has been shown to occur at early times for a semi-crystalline polymer, corresponding to its solubility limit in the solvent. However, the PCBM aggregation was hampered by the presence of the polymer and could only be detected during the last seconds of a slow drying wet film [73].

Manipulation of the drying conditions via solvent annealing has shown that faster drying can quench the polymer crystallization and yield smaller polymer crystals [74]. To understand the morphology formation the drying process need to be investigated in-situ. However, before addressing the available techniques the standard film coating methods used for polymer solar cells are briefly introduced.

\section{Thin film coating methods}

Spin coating is the standard small scale laboratory coating method. However, blade coating is also used and over the past years more research groups are moving towards R2R compatible slot die coating. The techniques are illustrated in Figure 5.2 where the deposition of the ink is followed by either a rotational or a blade movement for spin and blade coating respectively, smearing out the ink to a wet film that dries to a thin film.
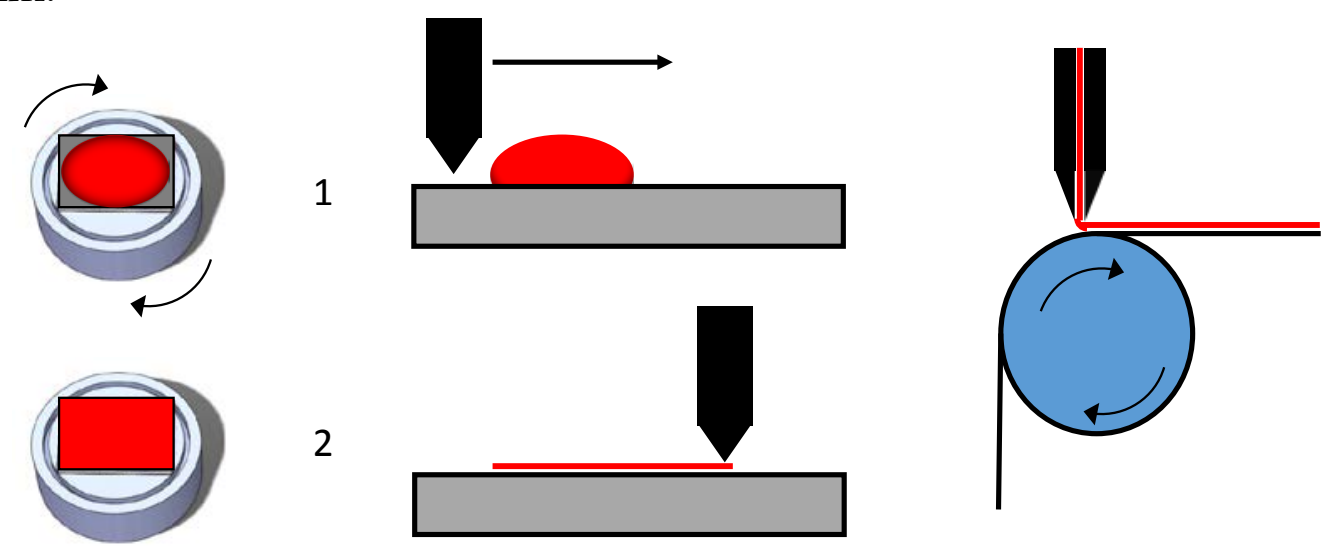

Figure 5.2 From left spin, blade- and slot die coating where the ink is deposited as a drop in step 1 and then spun or blade coated in step 2 to a wet film that dries to a solid thin film.

In the initial spin-coating stages ink is thrown off the substrate, while in the later drying stage the drying process is solvent evaporation dominated, whereas the bladeand slot die coating drying processes are solely governed by evaporation. 


\section{In-situ morphology monitoring}

To monitor the drying kinetics and the rate of wet film thinning laser reflectometry has been widely used. A wet thin film drying on a reflective substrate generates an oscillating reflectance as the conditions for constructive and destructive interference are alternatingly fulfilled as a function of the decreasing wet film thickness. From a known dry film thickness $h_{D R Y}$ the wet film thickness $h(t)$ can be back-calculated for the drying process. Thus, the drying rate can be determined from $d h / d t$ and the fraction of solid content $\phi$ in the drying film can be determined from

$$
\phi(t)=\frac{h_{D R Y}}{h(t)}
$$

For spatial resolution more reflectometer lasers can be added [75]. However, for large areas it quickly gets impractical. In paper 3 we introduce reflectance imaging for lateral monitoring of the drying kinetics. By recording thin film reflectance with a video camera generated by spectrally narrow LED illumination source diffused to illuminate the full area of the sample, we identify variations in drying rate over the surface of both spin- and blade-coated devices.

Figure 5.3a shows snapshots from the drying video for a blade coated TQ1:PCBM film cast from a mixed solvent. The initial rapid fringe oscillations shown in Figure $5.3 \mathrm{~b}$ display a fast drying regime as the more volatile solvent evaporate. The later drying stage with a reduced fringe frequency shows that most of the volatile solvent has left the film and the high boiling point solvent evaporation dominates the film thinning. From the drying video lateral variations in drying rate due to a directed air flow over the wet film are visualized for both the fast and slow drying time regimes shown in Figure 5.3c and d respectively.

In paper 4 we observe a variation in $J_{S C}$ of over $25 \%$ for spin coated TQ1:PC ${ }_{71} \mathrm{BM}$ solar cells from the same substrate. The variation was found to correlate with the solar cell distance to the center of rotation, where the domains further away also displayed a finer morphology. Using reflectance imaging we could identify the higher performing areas as areas with a higher wet film drying rate. 


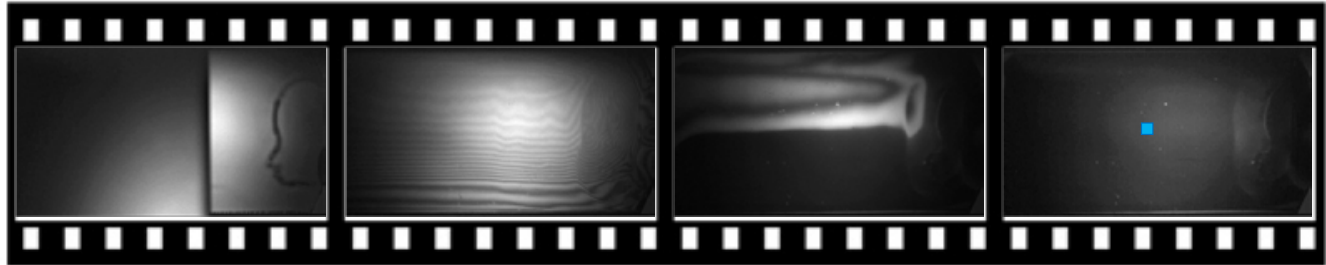

b
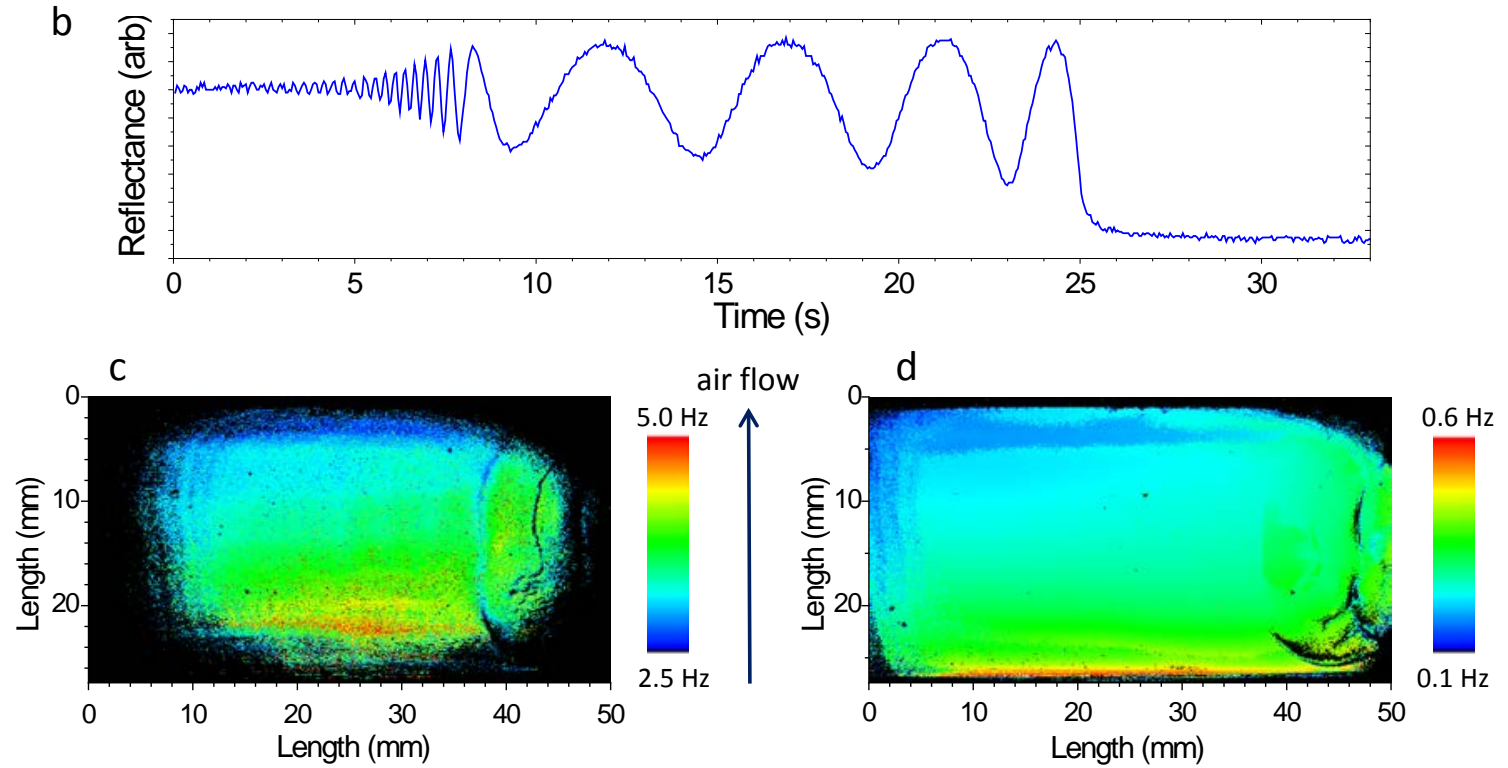

Figure 5.3 (a) Snapshots from a blade coated drying TQ1:PCBM. (b) Reflectance from the central blue pixel. (c-d) Lateral average film thinning frequency for the fast and slow drying phase respectively. The drying rate gradient is caused by an airflow over the sample. Reprinted from "Solar Energy Materials \& Solar Cells, 114, Jonas Bergqvist, Scott A. Mauger, Kristofer Tvingstedt, Hans Arwin, Olle Inganäs, In situ reflectance imaging of organic thin film formation from solution deposition, 89-98., Copyright (2013), with permission from Elsevier.

To probe the evolution of the morphology in-situ x-ray scattering has been used to determine the onset of crystallization for semi-crystalline polymers [73,76] and for PCBM $[73,77]$. Recently also an optical method to probe the morphology formation by a combination of absorption, reflectance and scattering was introduced [65]. In this study the role of a co-solvent was explained and liquid-liquid demixing could be observed indirectly via the onset of scattering. Furthermore, laser reflectometry has been used to study the drying process of polymer:polymer films where the onset of phase separation have been identified from the onset of scattering [78,79]. However, the x-ray methods can only detect crystalline materials while the onset of scattering is an indirect probe of phase separation.

In paper 5 we develop a new method using in-situ PL spectroscopy where we can detect the aggregation onsets of pure PCBM and polymer during drying when cast from solution. Furthermore, we also study the formation of the morphology of TQ1:PCBM blends during drying. We record the full PL spectra during the drying 

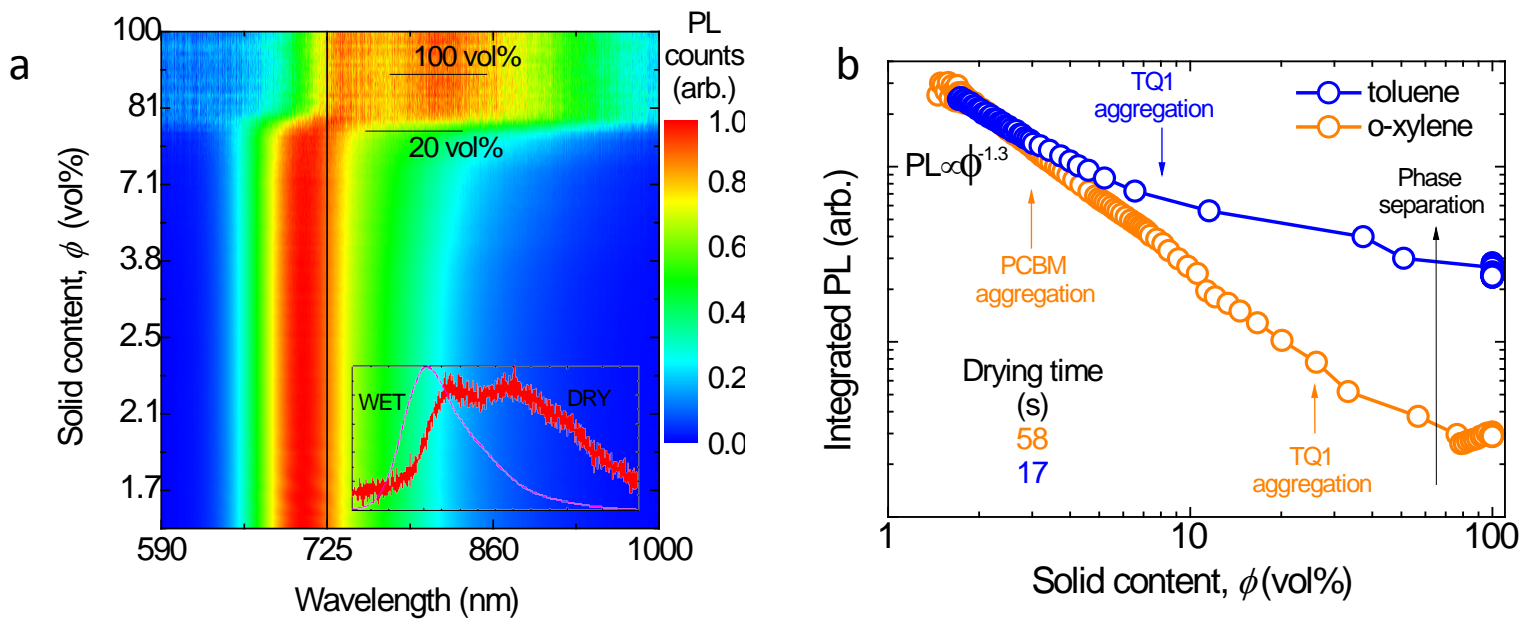

Figure 5.4 (a) Normalized spectral PL as a function of solid content $\phi$ for TQ1:PCBM drying from o-xylene. The inset shows the normalized PL spectra for the just cast wet film and the dry film. (b) Integrated PL as a function of $\phi$ for TQ1:PCBM films cast from toluene and o-xylene. The onsets for aggregation of pure TQ1 and PCBM during drying are marked with arrows.

process and are able to follow the transition from a polymer dominated emission to CT dominated at a late stage of the drying process as a function of $\phi$, shown in Figure 5.4a.

Furthermore, from the integrated PL as a function of $\phi$ we detect phase separation in the drying solution from a reduced PL quench rate. Figure $5.4 \mathrm{~b}$ shows the integrated PL emission as a function $\phi$ for two different solvents, where the o-xylene cast film displays a continuous PL quench and reaches as a fine morphology, whereas the film cast from the worse solvent toluene renders a coarse morphology, as predicted by the reduced PL quench rate during the drying. As an efficient PL quench is a signature of efficient exciton dissociation, in-situ PL spectroscopy may become a useful tool for ink development. 


\section{Morphology characterization}

The most used techniques to study the $\mathrm{BHJ}$ morphology and their possibilities are found in reference [80]. Listed below are brief descriptions of the most frequently used techniques in the papers included in this thesis.

\section{Atomic Force Microscopy}

Atomic Force Microscopy (AFM) is a standard tool for surface topography measurements. The method measures the forces between a tip mounted at the end of a cantilever and the sample. Different operation modes are possible where the tapping mode is commonly used to avoid the tip sticking to the surface. A piezoelectric element oscillates a cantilever and laser light reflected on the cantilever backside is used to measure the oscillation frequency, amplitude and phase of the cantilever. By scanning the tip over a sample and mapping the variations in interaction forces between the sample and the tip, a topography image is generated where the lateral resolution is determined by the tip size which commonly is a few tenth of $\mathrm{nm}$, whereas the height resolution is sub $\mathrm{nm}$.

\section{Transmission Electron Microscopy}

Transmission Electron Microscopy is used to image the full depth of a sample under measure. Electrons are accelerated to high speeds and shot at the sample and the degree of scattering upon transmission through the investigated sample is detected, where the degree of electron scattering is proportional to the electron density in the material. By applying a threshold to the scattering an image can be generated identifying domains of different electron density. In polymer solar cells contrast is sought between conjugated polymers and fullerenes. As both materials are carbon based a contrast is hard to get, but if phase separation occurs into rather pure domains a contrast is possible. However, the image is an integration over the sample thickness. For depth resolution Electron Tomography enables a 3D reconstruction of the sample from TEM images at tilted angles [81].

\section{Electroluminescence}

Conjugated polymers can be used as the emissive layer for organic light emitting diodes [82] where electrons are injected and light emitted upon recombination in the polymer layer. Also conjugated polymers for organic solar cells have a decent radiative recombination yield. However, in fine blends with PCBM the polymer electroluminescence (EL) is quenched due to charge transfer. Emission from the lower energy charge transfer state can be detected but the quantum efficiency for EL 
CT emission is in the order of $10^{-7}$ for many polymer:PCBM blends [29]. Electroluminescence can thus be used as a probe for pure phases percolating the active layer as recombination in these will radiate at the polymer or PCBM emission energy, whereas the absence of pure emission implies a fine blend.

\section{Photoluminescence}

For photoluminescence (PL) spectroscopy the excitation is optical, commonly by a laser. The emission from the pure materials are quenched upon charge transfer and as the CT state is weakly emissive the PL quenching efficiency

$$
\varphi_{P L}=1-\frac{\int P L_{B L E N D}(\lambda) d \lambda}{\int P L_{P O L Y M E R}(\lambda) d \lambda}
$$

is used as a probe for the charge transfer efficiency. Furthermore, if the pure emission is sufficiently quenched a CT emission band can be observed, also this an indication of a well mixed morphology.

\section{BHJ thermal stability}

The rapid drying of OPV inks results in a frozen-in morphology, and even if phase separation occurs during the drying process the final dry morphology are rarely at equilibrium. The frozen-in morphology is rather stable for temperatures below the glass transition temperature $\left(T_{g}\right)$. However, at elevated temperatures the polymers and fullerenes tend to phase separate.

The criteria's for thermal stability in polymer solar cells are determined from the demands on long time solar cell operation as well as from the R2R coating conditions. During solar cell operation the temperature in the solar cell can reach $85^{\circ} \mathrm{C}$ and this temperature is also the maximum temperature in the stability tests used in the international summit on OPV stability testing protocol ISOS [83]. Thus, morphology evolution must be limited at this temperature, to avoid large scale phase separation.

During R2R printing and coating heat ovens are used to enhance the drying rate of the inks and ensure a high speed production. The temperatures used in these ovens are limited by the substrates. As a low cost technology polyethyleneterephtalate (PET) foils are commonly used at substrates, which limits the processing temperatures to $140^{\circ} \mathrm{C}$. However, more expensive substrates compatible with higher processing temperatures may also be used.

Annealing of semi-crystalline polymer:PCBM blends can promote polymer crystallization [84] and increase the solar cell performance partly via enhanced absorption and charge carrier mobility in the materials [85]. On the other hand, 
annealing amorphous polymer:PCBM blends at temperatures above $T_{g}$ commonly results in a rapid coarsening of the nanostructure due to PCBM crystallization. Crystals in the $\mu \mathrm{m}$ scale can form also in $\sim 100 \mathrm{~nm}$ thin layers. Figure $5.5 \mathrm{a}$ shows micrographs of $\mathrm{PC}_{61} \mathrm{BM}$ crystals formed after annealing a film with $80 \mathrm{wt} \% \mathrm{PC}_{61} \mathrm{BM}$ dispersed in the amorphous polymer poly [(9,9-dioctylfluorenyl-2,7-diyl)-alt-5,5-(4',7'-di-2thienyl-2',1',3'-benzothiadiazole)] (APFO-3) at $220^{\circ} \mathrm{C}$. In Figure 5.5b the film has been preannealed at $130{ }^{\circ} \mathrm{C}$ leading to more but smaller crystals. These large $\mathrm{PC}_{61} \mathrm{BM}$ crystals are detrimental for solar cell performance.

The amorphous polymer TQ1 has shown PCEs of 6-7\% [86,87] and is also suitable for $\mathrm{R} 2 \mathrm{R}$ coating [88]. The $T_{g}$ for TQ1:PC ${ }_{61} \mathrm{BM} 1: 1$ is $\sim 110^{\circ} \mathrm{C}$ [89]. TQ1:PC ${ }_{11} \mathrm{BM} 1: 1$ films annealed at $140^{\circ} \mathrm{C}$ display a total loss of photocurrent due to large scale $\mathrm{PC}_{61} \mathrm{BM}$ crystallization. However, by adding naked $\mathrm{C}_{60}$ fullerenes to the TQ1:PC ${ }_{61} \mathrm{BM}$ blend the thermal stability is drastically improved as the $\mathrm{C}_{60}$ acts as a nucleation agent, which results in many small crystals [90], still allowing for exciton dissociation.
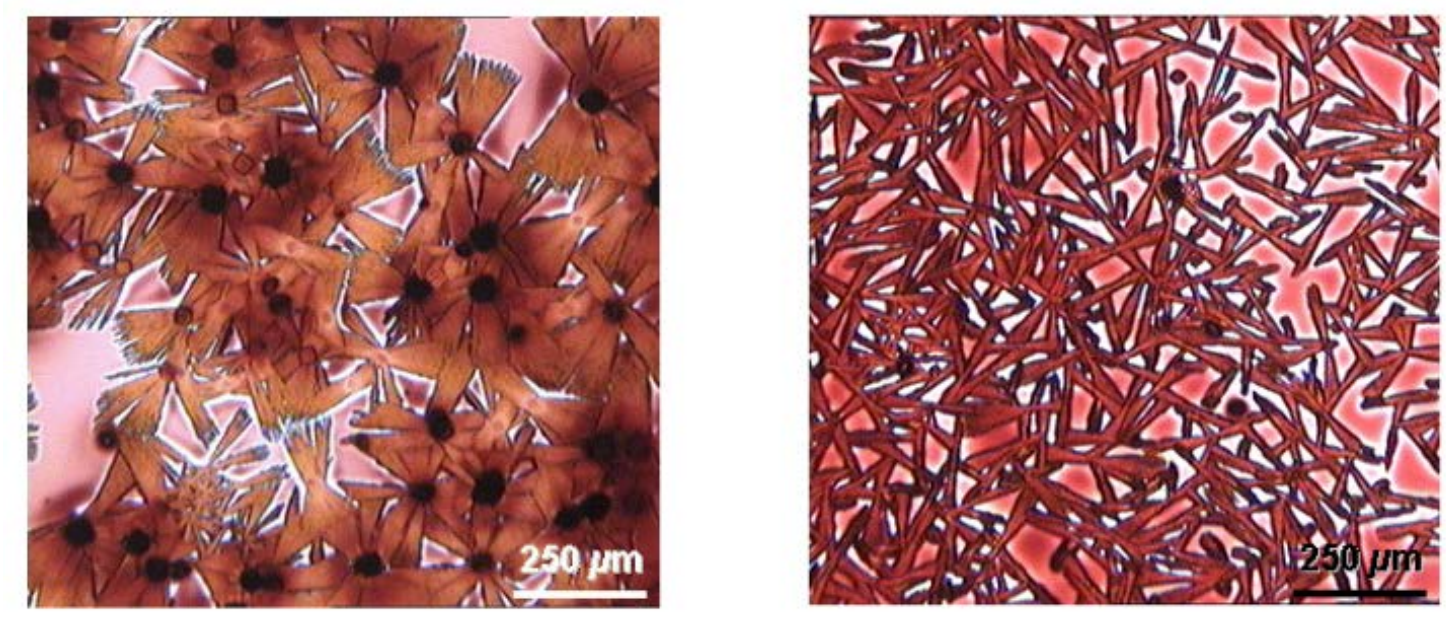

Figure 5.5 Optical micrographs of APFO3:PCBM 1:4 films after annealing at $220{ }^{\circ} \mathrm{C}$ without (a) and with (b) preannealing at $130{ }^{\circ} \mathrm{C}$. Adapted from J. Mater. Chem., 2011, 21, 10676, DOI: 10.1039/C1JM11239B with permission from The Royal Society of Chemistry.

TQ1:PC ${ }_{71} \mathrm{BM}$ has a higher thermal stability due to a higher $T_{g}$. However, the yield of $\mathrm{C}_{60} / \mathrm{C}_{70}$ is $\approx 1: 4$ upon fullerene synthesis, making $\mathrm{PC}_{71} \mathrm{BM}$ more expensive. Nevertheless, by using the native blend the PCBM crystallization can be drastically reduced and device performance maintained [91].

However, the effects of annealing non-crystalline finely intermixed polymer:PCBM blends below $T_{g}$ have not been intensively investigated. In paper 6 we show that a mild annealing of TQ1:PCBM active layers at temperatures below $T_{g}$ leads to local conformation changes of TQ1 as detected via a redshifted absorption, while AFM 
and TEM images are unable to resolve a coarsening of the morphology. Also the solar cell performance increases by enhancements in $F F$ and $J_{S C}$. We propose that local TQ1 conformation changes and limited fullerene aggregation locally improves the charge carrier mobility and that the redshifted TQ1 absorption contributes to an enhanced photocurrent. Thus, gentle annealing of a finely intermixed blend can be used to optimize the material performance which also is highly attractive for R2R processing, where the coated layers are dried in ovens. 


\section{Chapter 6}

\section{Optoelectrical imaging}

$J V$-characteristics of solar cells can identify defect devices. However, to distinguish between global and localized defects lateral resolution is necessary. Hence, for the upscaling of printed polymer solar cells, and also for the move from small lab cells to $\mathrm{R} 2 \mathrm{R}$ produced large area solar cells, imaging methods are essential. A number of imaging methods have been developed for the silicon solar cell research and quality control such as lock-in thermography (LIT) [92,93], PL and EL luminescence imaging [94,95] and photocurrent imaging [96]. These methods have also been successfully transferred to image organic solar cells.

\section{OPV imaging methods}

The commonly used large area imaging methods for polymer solar cells are listed below, whereas a more profound summary is found in reference [97].

\section{Lock-in thermography}

LIT is a thermal imaging method where temperature variations below $\mathrm{mK}$ is detectable. The sample is mounted on a heat sink to have a controlled temperature and is thermally excited either electrically by a modulated voltage or optically by an amplitude modulated light source. An infrared camera is used to image local resistive heating and the technique is especially suited to detect short circuit hot spots. LIT has been used to study organic solar cells where areas with low parallel resistance have been identified [98].

\section{Luminescence imaging}

PL imaging samples are excited by a homogenous illumination from a LED while an electrical excitation is used for EL imaging. The luminescence is detected using a silicon charge-coupled device with an optical filter to block the excitation light. Additional filters can be used to selectively image pure material or CT emission. The 
PL images provide information of the active layer morphology while EL also probes the injection at the contacts. Thus, the combination of both methods allows for differentiation of active layer and electrode defects [99]. The resolution of the images is dependent on the number of pixels in the camera and the signal to noise ratio and can be down to a few microns.

\section{Photocurrent imaging}

Light Beam Induced Current (LBIC) is strictly speaking not an imaging method, but rather a mapping method, where a focused laser beam is raster, or point-by-point, scanned over the solar cell area. Commonly, and in this thesis, an amplitude modulated light source is used together with a lock-in amplifier to detect only the locally generated photocurrent and to increase the signal to noise ratio. Using a computer algorithm to synchronize the spatial measurement with its corresponding photocurrent, photocurrent images are rendered. The resolution is determined by the size of the focused laser spot and the pixel density and is commonly $\sim 100 \mu \mathrm{m}$, but for a highly focused laser beam down to a few $\mu \mathrm{m}$.

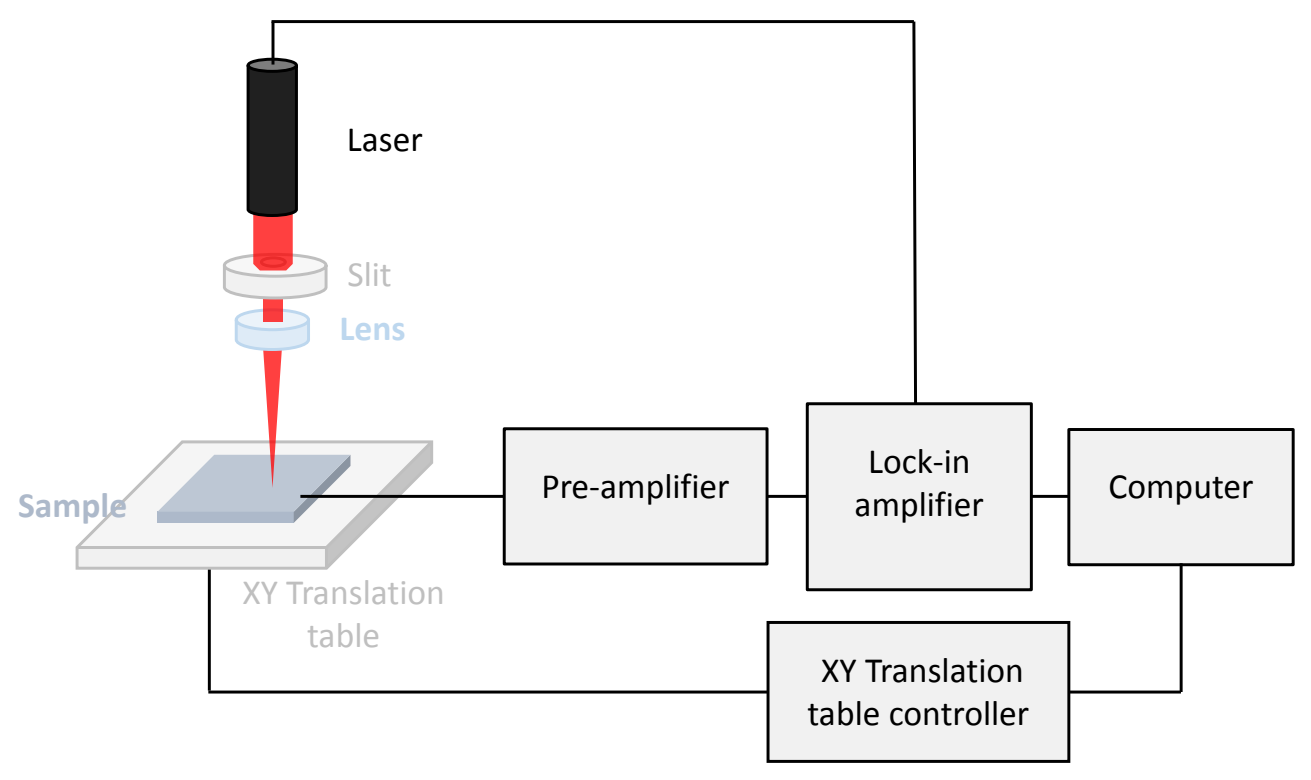

Figure 6.1 LBIC measurement setup

The laser is scanned either using rotary mirrors with the solar cell at a fixed location, or a fixed laser and the solar cell mounted on a translation stage. For small scale laboratory devices the translation stage is the most common and Figure 6.1 shows the measurement setup. The translation stage may severely limit the speed of the measurement due to limitations in the sample translation. The LBIC setup used in this thesis has both a point-by-point mode, but also a continuous translation mode along one axis. Using rotary mirrors the measurement speed can be further enhanced as discussed in the next chapter. 


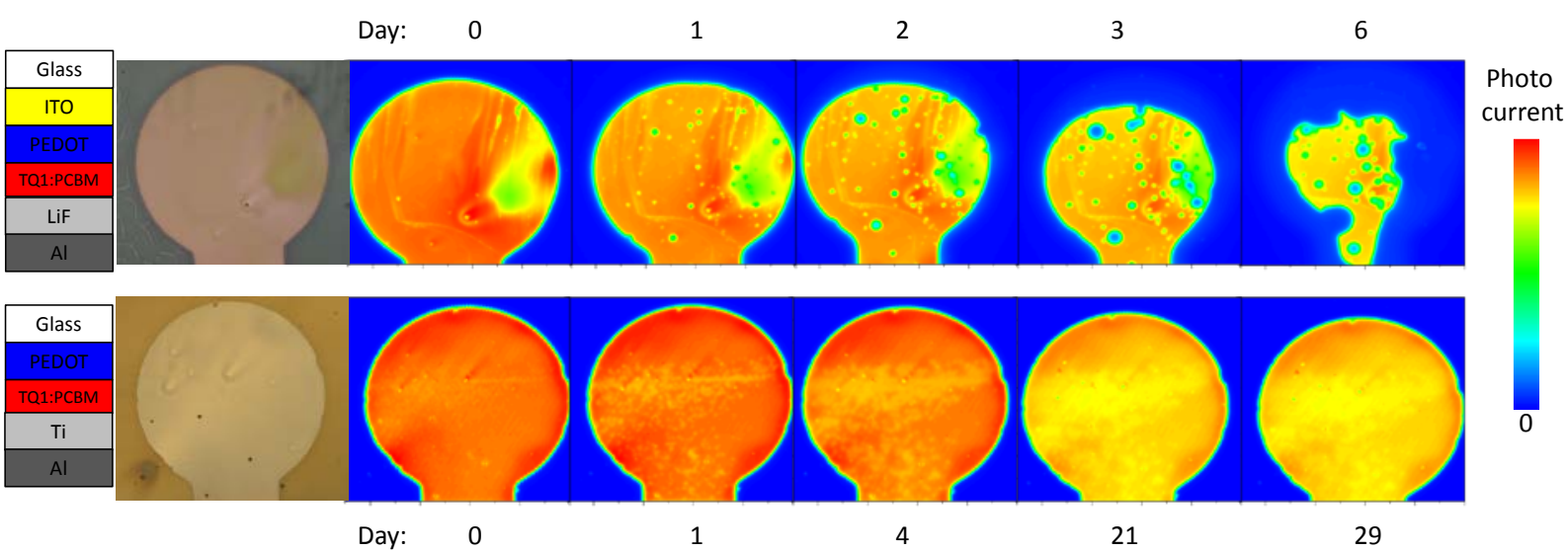

Figure 6.2 The degradation over time for $4 \mathrm{~mm}^{2}$ TQ1:PCBM solar cells in standard (top row) and reversed (lower row) geometry imaged by LBIC.

The imaging techniques introduced have been extensively used for characterization of the degradation mechanisms in different OPV geometries [100]. A common degradation path for standard geometry solar cells are from oxidation of the aluminum electrode by water ingress [101,102]. Figure 6.2 shows photocurrent images recorded over a number of days to study the degradation for a standard and a reversed geometry solar cell. The standard cell degrades faster with the growth of oxidized aluminum domains both from pinholes in the aluminum and by water ingress from the sides.

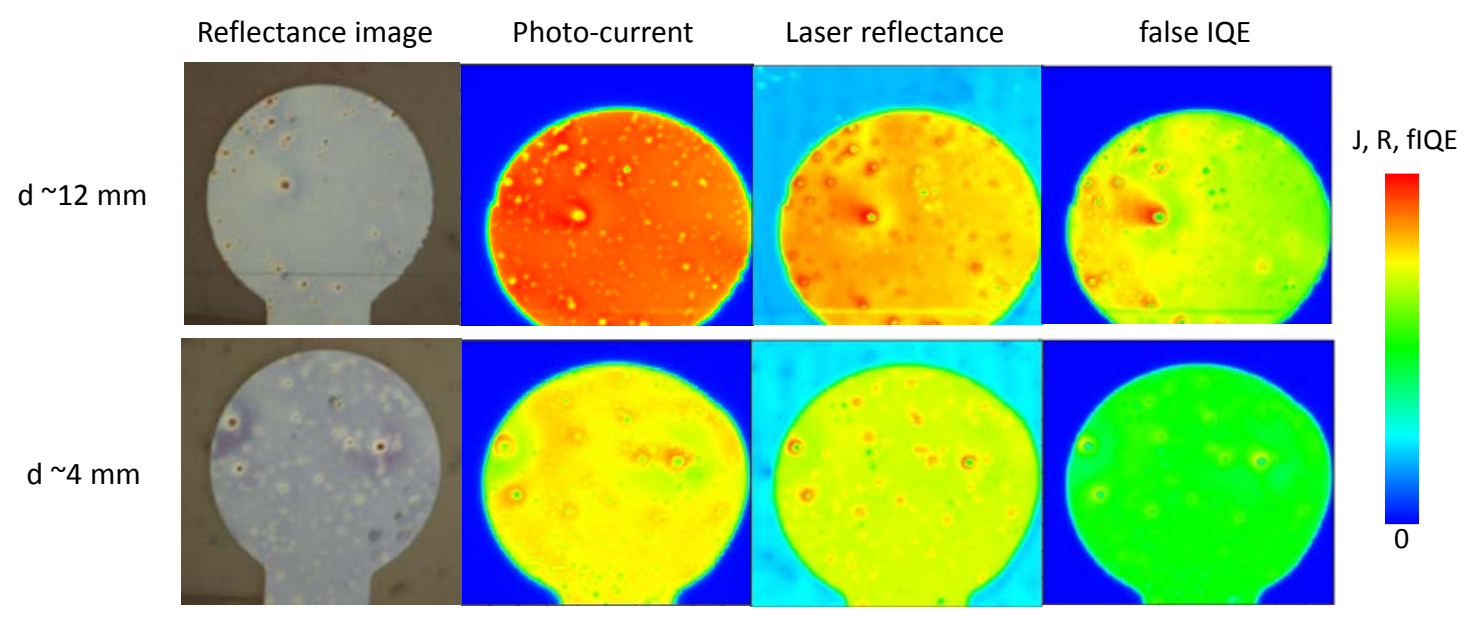

Figure 6.3 Reflectance microscope, photocurrent, laser reflectance and false IQE for solar cells far from (top) and close to (bottom) the center of rotation.

A variation of the photocurrent with respect to the pixel distance to the center of rotation for spin-coated devices was noticed in paper 4. Photocurrent images confirmed the recorded $J V$-data and by the addition of a photodetector measuring the specular reflectance also the so called "false" IQE could be imaged, where the 
"false" comes from the determination of absorptance in the active layer being calculated by $1-R$, neglecting parasitic electrode absorption. Figure 6.3 shows a reflecting microscope image of the measured devices along with the photocurrent, reflectance and false IQE images recorded by LBIC. The higher "false" IQE for the device at $d \sim 12 \mathrm{~mm}$ strengthened the hypothesis of an increasing $I Q E$ further away from the center of rotation.

\section{Recombination imaging}

LBIC is an effective method to image lateral variations in the photocurrent generation caused by defects, shorts and non-optimal processing. However, it is not possible to distinguish between different recombination loss channels. Polymer solar cells commonly have a non-optimal $F F$ and a forward bias approaching $P_{M A X}$ commonly results in significant recombination losses.

As discussed in the recombination section in Chapter 3 the losses in high performing polymer solar cells are believed to be dominated by bimolecular processes [31], a process proportional the illumination intensity squared. There are numerous measurement techniques used to identify the recombination processes [103], but they are limited to single pixel measurements and not easily transferred to a mapping or imaging mode. However, utilization of the non-linear light intensity dependence allows for a modification of the LBIC setup to qualitatively measure second order recombination as a non-linearity in photocurrent. However, first non-linear systems are briefly introduced.

\section{Non-linear systems}

A system is defined with $x(t)$ as the input signal and the system response $y(t)$. If $x(t)=x_{1}(t)+x_{2}(t)$ the linear system response is the superposition $y(t)=$ $y_{1}(t)+y_{2}(t)$. For a harmonic signal $x(t)=A \cos (\omega t)$, where $\omega$ is the angular frequency, the linear response is $y(t)=B \cos (\omega t+\phi)$ with a modified amplitude $B$ and a phase shift $\phi$ introduced.

For a second order non-linear system the response on the harmonic input signal is

$$
y(t) \propto x(t)^{2}=(A \cos (\omega t))^{2}=\frac{A^{2}}{2}+\frac{A^{2}}{2} \cos (2 \omega t+\phi)
$$

where $y(t)$ now contains the frequency component $2 \omega$, the second harmonic of $\omega$. Consequently a third order non-linear system responds with third harmonics and so on.

If $x(t)$ is a superposition of two harmonic functions the response $y(t)$ for a second order non-linear system, ignoring the phase shifts, are 


$$
\begin{gathered}
y(t) \propto x(t)^{2}=\left(\cos \left(\omega_{1} t\right)+\cos \left(\omega_{2} t\right)\right)^{2}= \\
\ldots \cos \left(2 \omega_{1} t\right)+\cos \left(2 \omega_{2} t\right)+\cos \left(\left(\omega_{1}+\omega_{2}\right) t\right)+\cos \left(\left(\omega_{1}-\omega_{2}\right) t\right)
\end{gathered}
$$

where the amplitudes and static terms are neglected. The mixing frequencies $\omega_{1}+$ $\omega_{2}$ and $\omega_{1}-\omega_{2}$ are known as intermodulation frequencies $\omega_{I M P}$. Thus, the presence of second harmonics and second order $\omega_{I M P}$ is a signature of a second order non-linear system.

\section{Intermodulation-LBIC}

The LBIC laser is amplitude modulated at $\omega$. Hence, if the solar cell has a non-linear response it should be visible in the harmonics of $\omega$. To detect the order of nonlinearity the lock-in amplifier should simply be set to lock in to harmonic frequencies. However, the lasers used for illumination are commonly non-linear, thereby also the light source generates harmonics of $\omega$.

A non-linear response from the solar cell then superimpose with the laser generated harmonics. To circumvent the subtraction of a non-linear solar cell signal from the laser overtones we instead utilize the intermodulation $\omega_{I M P}$ frequency to detect solar cell non-linearities in paper 7. A second laser was added to the LBIC setup and both lasers were modulated at individual frequencies. Figure 6.4 shows the linear frequency response of two lasers amplitude modulated at $\omega_{1}$ and $\omega_{2}$ in blue, and their second harmonics $2 \omega$ in green, their harmonics $3 \omega$ in yellow, and the second order $\omega_{I M P}$ in red.

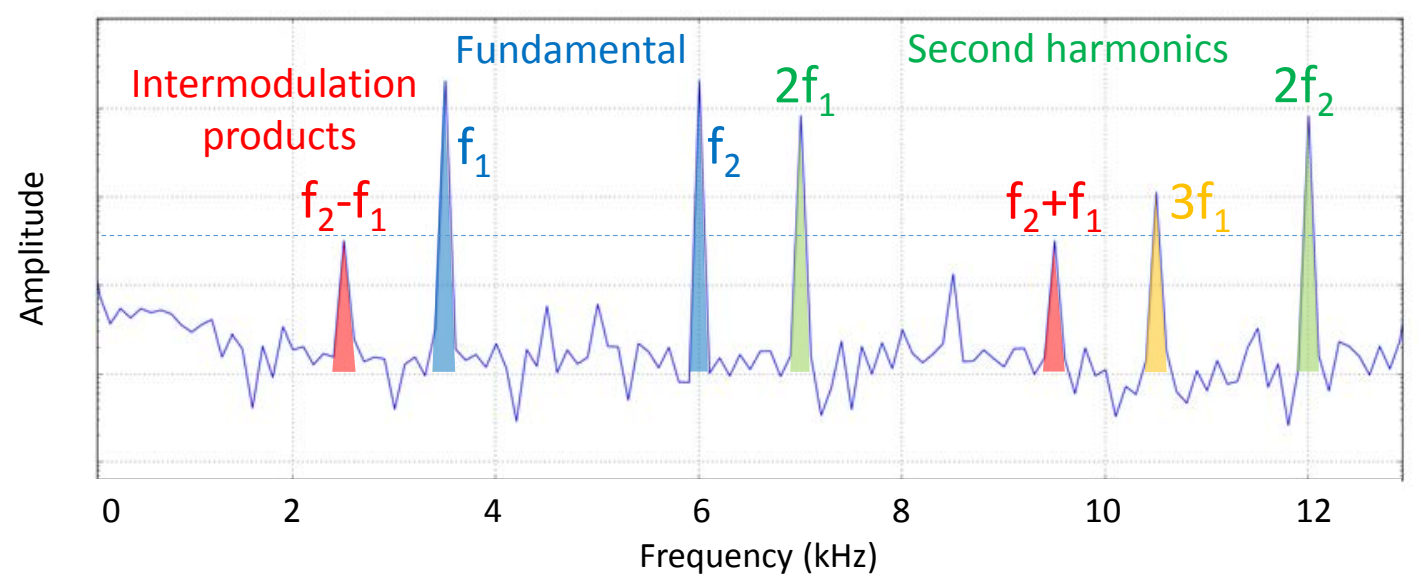

Figure 6.4 Frequency response of a TQ1:PCBM solar cell illuminated with two lasers modulated at $\mathrm{f} 1$ and $\mathrm{f} 2$

From drift-diffusion simulations [104] the typical non-linear response was modelled for different recombination mechanisms and a characteristic signature of $\omega_{I M P}$ was identified for bimolecular recombination. We utilize this signature of $\omega_{I M P}$ as a trace 
for bimolecular recombination which allows us to qualitatively map the second order IMP response simultaneously with the photocurrent maps. Figure 6.5a shows the voltage dependence of the linear and IMP response. The IMP signal increases as expected for low applied voltages when the photocurrent decreases, as this is a direct consequence of increased recombination. In Figure 6.5b linear photocurrent maps at reverse voltage and $J_{S C}$ are shown together with the linear response where areas with lower photocurrent also yields a stronger response at $\omega_{I M P}$.

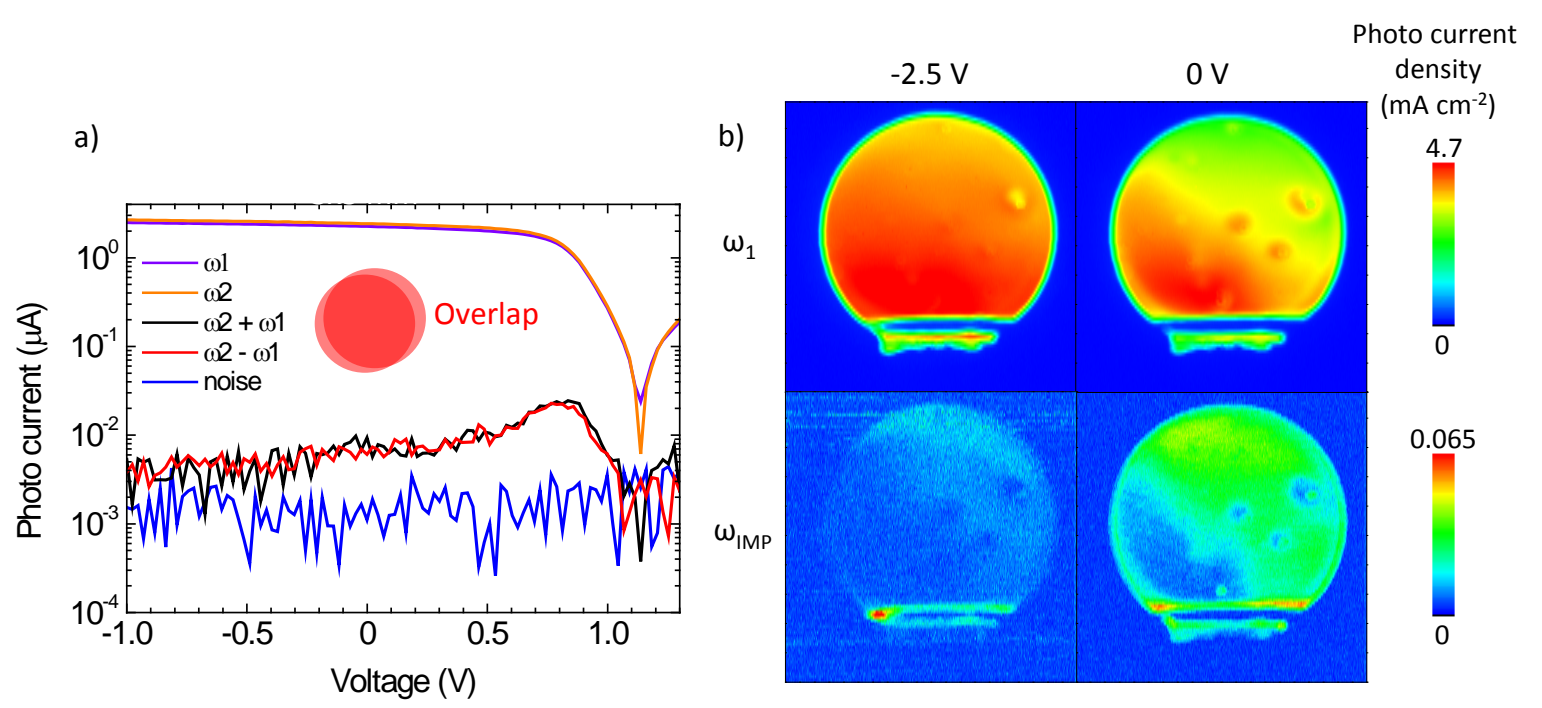

Figure 6.5 Voltage dependence of the linear and IMP response (a) and IMLBIC images of the linear and IMP to linear ratio under reverse and forward bias. 


\section{Imaging of modules}

The main advantage of polymer solar cells is the potentially very low manufacturing cost achieved via R2R coating and printing methods. However, already at the research stage the coating processes quickly produces so large volumes that high speed automatized characterization methods are necessary [105]. Polymer solar cell modules are commonly coated in a configuration with subcell stripes monolithically series connected as illustrated in Figure 6.6. The low conductivity of the transparent top electrode limits the solar cell area. Therefore the modules are commonly printed as narrow stripes connected in series where the current flows orthogonal to the stripe direction to limit resistive losses in the transparent top electrode.

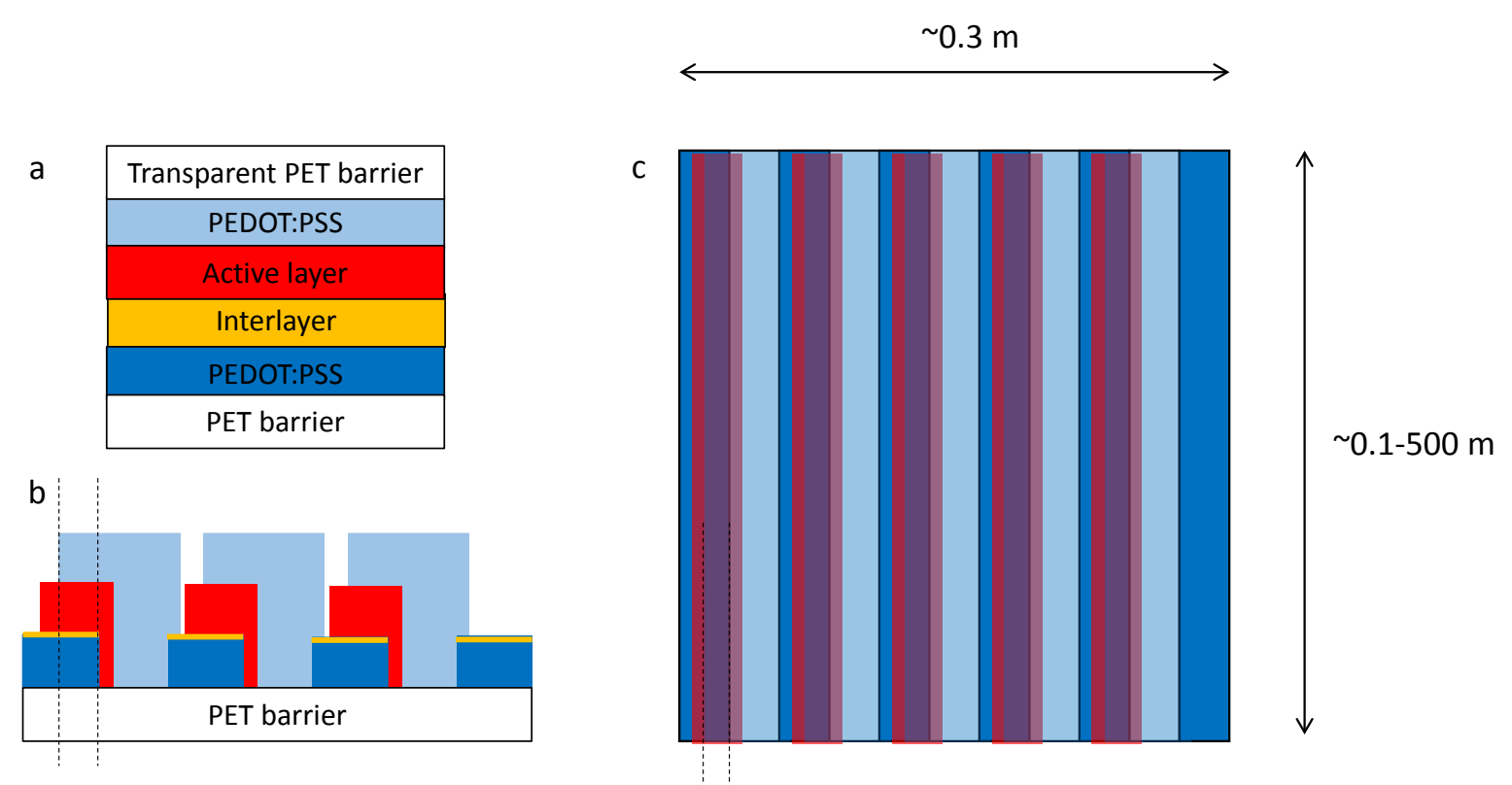

Figure 6.6 (a) Typical module solar cell stack excluding the current collectors. (b) Module side view showing the translation of each layer and the contact between anode (dark blue) and cathode (light blue). The overlap between dark (cathode) and light blue (anode) electrode layers constitutes the series connection. (c) Top view of a series connected OPV module. The dotted lines in b and $\mathrm{c}$ highlight the active solar cell area.

$J \mathrm{~V}$-characterization under simulated solar light can be used in-line, but would be limited to a few voltage points at high web speeds. Further, this only gives the global solar cell response which will identify defect modules, but with limited possibilities to troubleshooting. Thus, an imaging method able to reveal the location, and preferably the cause, for a malfunctioning module is necessary for the further development.

LIT have been used to image modules [106,107] while a combination of DLIT, PL, EL and reflectance imaging have successfully been used to identify defects in R2R printed modules [108]. However, of these methods only the optical reflectance inspection is suitable for high speed in-line characterization due to the long 
measurement times needed for the other methods. Still, much information can be extracted from optical inspection in either reflectance or transmission mode, such as film quality and thickness. By matching the individual absorption spectra of the printed layers with the illumination source used for optical inspection the layers can be individually addressed and high speed cameras enable high resolutions.

However, even if all layers appear perfectly coated there may still be low performance, due to poor active layer morphology, or short circuits by dissolution of underlying layers or electrodes penetrating the active layer. Consequently, an optoelectrical imaging method probing the actual photocurrent extraction is required. LBIC can be operated at high speeds with a mirror galvanometer to sweep the large area solar cells is two dimensions rendering a photocurrent image [109]. Krebs and Jörgensen introduced a rotating mirrors LBIC for $\mathrm{R} 2 \mathrm{R}$ in-line measurements where the laser is scanned over the web [105]. In this work they further introduce an elegant capacitive contact by using two metal plates at the module edges overlapping the current collecting busbars in the solar module. The LBIC response could then be measured by using an amplitude modulated laser as the light source without the need of any physical contacts.

However, the interpretation of the photo current response from LBIC measurements on modules is not straight forward. For series connected modules the LBIC response is also depending on the shunt resistance of the illuminated cell and also the shunt resistance of the other subcells. Applying a background bias illumination on the module can facilitate the interpretation, albeit even small inhomogeneities in the background illumination will shift the voltage over the subcells [110]. Nevertheless, a combination of LIT and LBIC have shown a trend where short circuited subcells also displayed a lower LBIC signal [111] as expected.

The use of multiple lasers in paper 7 inspired a further development of the LBIC system with a multitude of light sources. However, an array of lasers quickly become expensive, which is why we in paper 8 introduce LEDimage as a compact and static alternative illumination source to the rotary mirror laser beam. By modulating the LEDs in a $1 \mathrm{D}$ array at individual frequencies $\left(\mathrm{f}_{1}, \mathrm{f}_{2}, \ldots\right)$ and Fourier transforming the photocurrent response a photocurrent map is generated according to the principle shown in Figure 6.7 with all subcells illuminated during the measurement. Line scans renders a photocurrent image of the R2R printed polymer solar cell module. 


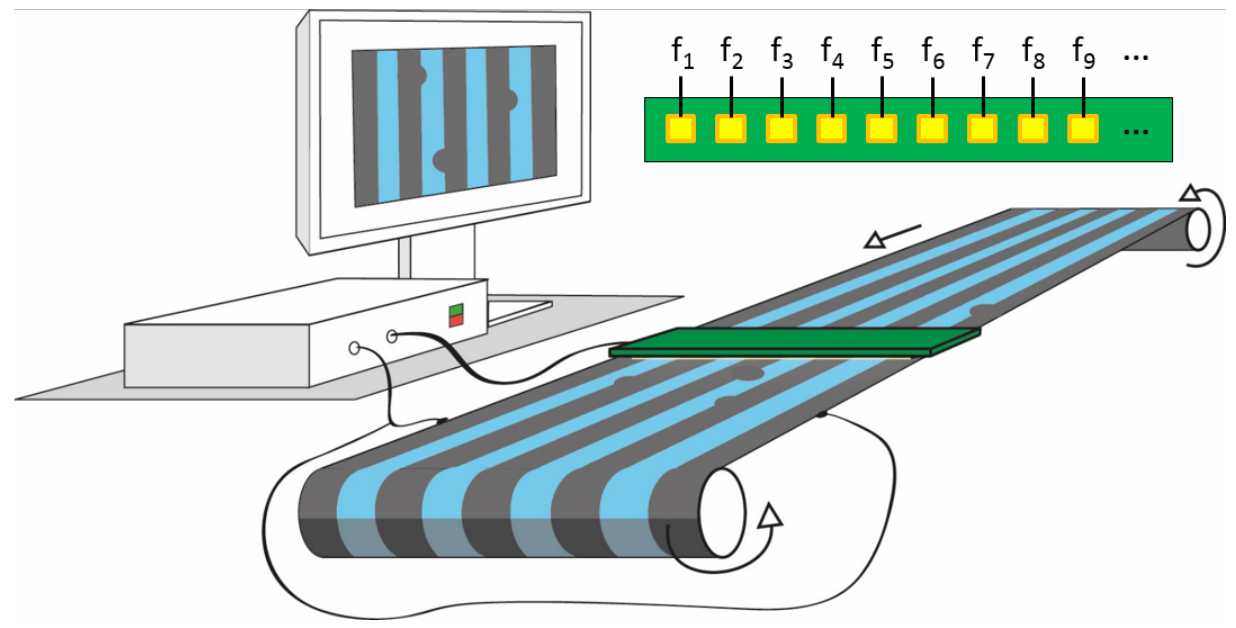

Figure 6.7 LEDimage with the LED array illuminating the solar cell web illustrated above the printing web.

By incorporating the LEDimage in a R2R polymer solar cell printing machine shown in Figure 6.8, we have verified the LEDimage function by scanning a commercial large module at web speeds of $1-5 \mathrm{~m} / \mathrm{min}$. The recorded photocurrent image are shown next to the LEDimage and identifies two defect (blue) areas in the top sections of the right subcell. Thus, LEDimage may be used as an in-line defect detection system and with additional studies potentially also as a full characterization system for the quality of each subcell in organic solar cell modules.
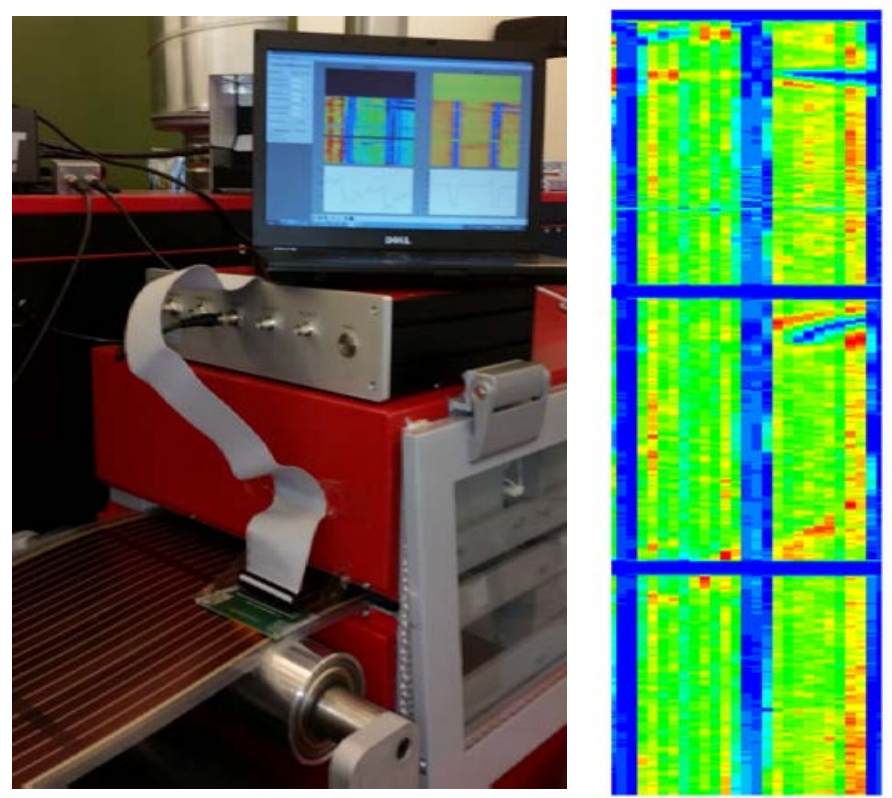

Figure 6.8 (a) LEDimage R2R in-line scan of an OPV module. (b) The corresponding photocurrent image of two serially connected adjacent cells divided in to three sections showing two defects (blue) with no photocurrent generation in the right subcell . 


\section{Chapter 7}

\section{Outlook}

My hope is that some of the results from this thesis may contribute to the understanding and further development of polymer solar cells.

An experimental validation of the TMM simulations and simulations of a full day solar illumination of vertically placed PEDOT:PSS based semitransparent solar cells would reveal the actual impact on light absorption of the anisotropic PEDOT:PSS electrodes.

Furthermore, the developed in-situ PL method could prove as an important complementary method for an improved understanding of the morphology formation and ink development. Further studies on material systems with known liquid-liquid and solid-liquid phase separation would confirm the validity while studies on material systems with spectrally separated peaks of donor, acceptor and CT emission would allow to probe the evolution of each component as well as the CT state during drying. Likewise, in-situ reflectance imaging would be very interesting to integrate on a $\mathrm{R} 2 \mathrm{R}$ printing machine to monitor variations in drying conditions for inks based on volatile solvents.

IMLBIC is an off-line method, but could be a useful method to identify whether the origin of lateral performance variations is caused by different recombination mechanisms. The LEDimage on the other hand has the potential to become a R2R quality control tool. However, further studies on modules are needed to interpret the subcell responses. Possibly also the non-linear response could aid in determining the voltage operation point of the subcells for two terminal LEDimage measurements.

In a broader perspective, for polymer solar cells to reach the market also the lifetime of the modules must be secured. Consequently, both materials and stacks needs further development to reach a stability where low cost barrier films are enough to guarantee long lifetimes.

To compete with silicon solar cells, and truly utilize the low tech and low cost production, the large $E_{C T}-q V_{O C}$ losses must to be understood and reduced. With reduced losses to $0.3-0.4 \mathrm{eV}$ efficiencies up to $20 \%$ is achievable also for polymer solar cells. Progress is being made in this field where a reduced donor:acceptor interface area may be one route to reduce the recombination rate and thus reach higher $V_{O C}$ [112]. 


\section{References}

[1] http://co2now.org/, 2015;

[2] Rockström, J., Steffen, W., Noone, K., Persson, Å., Chapin, F.S., Lambin, E.F., Lenton, T.M., Scheffer, M., Folke, C., Schellnhuber, H.J., Nykvist, B., De Wit, C.A., Hughes, T., Van Der Leeuw, S., Rodhe, H., Sörlin, S., Snyder, P.K., Costanza, R., Svedin, U., Falkenmark, M., Karlberg, L., Corell, R.W., Fabry, V.J., Hansen, J., Walker, B., Liverman, D., Richardson, K., Crutzen, P., Foley, J.A., A safe operating space for humanity, Nature. 2009; 461(7263) , pp. 472-475. DOI: 10.1038/461472a.

[3] Cleveland, C.J., Net energy from the extraction of oil and gas in the United States, Energy. 2005; 30(5) , pp. 769-782. DOI: 10.1016/j.energy.2004.05.023.

[4] Wurfel, P., Physics of Solar Cells: From Basic Principles to Advanced Concepts, 2nd ed., WILEY-VCH Verlag GmbH \& Co., Weinheim, 2009.

[5] Lewis, N.S., Crabtree, G., Basic Research Needs for Solar Energy Utilization: report of the Basic Energy Sciences Workshop on Solar Energy Utilization, US Department of Energy, Office of Basic Energy Science, Washington, DC, 2005.

http://resolver.caltech.edu/CaltechAUTHORS:LEWsolarenergyrpt05.

[6] Saleh, B.E.A., Teich, M.C., Fundamentals of Photonics, 2nd ed., John Wiley \& Sons, Inc., Hoboken, New Yersey, 2007.

[7] Born, M., Wolf, E., Principles of Optics, 7th ed., Cambridge University Press, 1999.

[8] Fujiwara, H., Spectroscopic Ellipsometry: Principles and Applications, John Wiley \& Sons, Ltd, 2003.

[9] Shirakawa, H., Louis, E.J., MacDiarmid, A.G., Chiang, C.K., Heeger, A.J., Synthesis of electrically conducting organic polymers: halogen derivatives of polyacetylene, $(\mathrm{CH}), \mathrm{J}$. Chem. Soc. Chem. Commun. 1977;(16) , pp. 578-580. DOI: 10.1039/C39770000578.

[10] Xia, Y., Sun, K., Ouyang, J., Solution-Processed Metallic Conducting Polymer Films as Transparent Electrode of Optoelectronic Devices, Adv. Mater. 2012; 24(18) , pp. 2436-2440. DOI: 10.1002/adma.201104795.

[11] Fabretto, M.V., Evans, D.R., Mueller, M., Zuber, K., Hojati-Talemi, P., Short, R.D., Wallace, G.G., Murphy, P.J., Polymeric Material with Metal-Like Conductivity for Next Generation Organic Electronic Devices, Chem. Mater. 2012; 24(20) , pp. 3998-4003. DOI: 10.1021/cm302899v.

[12] Knupfer, M., Exciton binding energies in organic semiconductors, Appl. Phys. Mater. Sci. Process. 2003; 77(5) , pp. 623-626. DOI: 10.1007/s00339-003-2182-9.

[13] Swinnen, A., Haeldermans, I., Vande Ven, M., D’Haen, J., Vanhoyland, G., Aresu, S., D’Olieslaeger, M., Manca, J., Tuning the dimensions of C60-based needlelike crystals in blended thin films, Adv. Funct. Mater. 2006; 16(6) , pp. 760-765. DOI: 10.1002/adfm.200500812.

[14] He, Y., Chen, H.-Y., Hou, J., Li, Y., Indene-C60 Bisadduct: A New Acceptor for HighPerformance Polymer Solar Cells, J. Am. Chem. Soc. 2010; 132(4) , pp. 1377-1382. DOI: 10.1021/ja908602j.

[15] Søndergaard, R., Hösel, M., Angmo, D., Larsen-Olsen, T.T., Krebs, F.C., Roll-to-roll fabrication of polymer solar cells, Mater. Today. 2012; 15(1-2) , pp. 36-49. DOI: 10.1016/S13697021(12)70019-6.

[16] Machui, F., Hosel, M., Li, N., Spyropoulos, G.D., Ameri, T., Sondergaard, R.R., Jorgensen, M., Scheel, A., Gaiser, D., Kreul, K., Lenssen, D., Legros, M., Lemaitre, N., Vilkman, M., Valimaki, M., Nordman, S., Brabec, C.J., Krebs, F.C., Cost analysis of roll-to-roll fabricated ITO free single and tandem organic solar modules based on data from manufacture, Energy Environ. Sci. 2014; 7(9) , pp. 2792-2802. DOI: 10.1039/C4EE01222D. 
[17] Mulligan, C.J., Wilson, M., Bryant, G., Vaughan, B., Zhou, X., Belcher, W.J., Dastoor, P.C., A projection of commercial-scale organic photovoltaic module costs, Sol. Energy Mater. Sol. Cells. 2014; 120, Part A(0) , pp. 9-17. DOI: 10.1016/j.solmat.2013.07.041.

[18] Espinosa, N., García-Valverde, R., Urbina, A., Lenzmann, F., Manceau, M., Angmo, D., Krebs, F.C., Life cycle assessment of ITO-free flexible polymer solar cells prepared by roll-to-roll coating and printing, Dedic. Glob. Org. Photovolt. GOPV Conf. Hangzhou China. 2012; 97 , pp. 3-13. DOI: 10.1016/j.solmat.2011.09.048.

[19] Weinberger, B.R., Akhtar, M., Gau, S.C., Polyacetylene photovoltaic devices, Synth. Met. 1982; 4(3) , pp. 187-197. DOI: 10.1016/0379-6779(82)90012-1.

[20] Tang, C.W., Two-layer organic photovoltaic cell, Appl. Phys. Lett. 1986; 48(2) , pp. 183-185. DOI: $10.1063 / 1.96937$.

[21] Lin, J.D.A., Mikhnenko, O.V., Chen, J., Masri, Z., Ruseckas, A., Mikhailovsky, A., Raab, R.P., Liu, J., Blom, P.W.M., Loi, M.A., Garcia-Cervera, C.J., Samuel, I.D.W., Nguyen, T.-Q., Systematic study of exciton diffusion length in organic semiconductors by six experimental methods, Mater. Horiz. 2014; 1(2) , pp. 280-285. DOI: 10.1039/C3MH00089C.

[22] Halls, J.J.M., Walsh, C.A., Greenham, N.C., Marseglla, E.A., Friend, R.H., Moratti, S.C., Holmes, A.B., Efficient photodiodes from interpenetrating polymer networks, Nature. 1995; 376(6540), pp. 498-500.

[23] Yu, G., Gao, J., Hummelen, J.C., Wudl, F., Heeger, A.J., Polymer photovoltaic cells: Enhanced efficiencies via a network of internal donor-acceptor heterojunctions, Science. 1995; 270(5243), pp. 1789-1791.

[24] Shockley, W., Queisser, H.J., Detailed Balance Limit of Efficiency of p-n Junction Solar Cells, J. Appl. Phys. 1961; 32(3) , pp. 510-519. DOI: http://dx.doi.org/10.1063/1.1736034.

[25] Green, M.A., Emery, K., Hishikawa, Y., Warta, W., Dunlop, E.D., Solar cell efficiency tables (version 46), Prog. Photovolt. Res. Appl. 2015; 23(7) , pp. 805-812. DOI: 10.1002/pip.2637.

[26] Scharber, M.C., Mühlbacher, D., Koppe, M., Denk, P., Waldauf, C., Heeger, A.J., Brabec, C.J., Design rules for donors in bulk-heterojunction solar cells - Towards $10 \%$ energy-conversion efficiency, Adv. Mater. 2006; 18(6) , pp. 789-794. DOI: 10.1002/adma.200501717.

[27] Goris, L., Poruba, A., Hod'Ákova, L., Vaněček, M., Haenen, K., Nesládek, M., Wagner, P., Vanderzande, D., De Schepper, L., Manca, J.V., Observation of the subgap optical absorption in polymer-fullerene blend solar cells, Appl. Phys. Lett. 2006; 88(5) , pp. 1-3. DOI: 10.1063/1.2171492.

[28] Vandewal, K., Ma, Z., Bergqvist, J., Tang, Z., Wang, E., Henriksson, P., Tvingstedt, K., Andersson, M.R., Zhang, F., Quantification of quantum efficiency and energy losses in low bandgap polymer: Fullerene solar cells with high open-circuit voltage, Adv. Funct. Mater. 2012; 22(16) , pp. 3480-3490. DOI: 10.1002/adfm.201200608.

[29] Vandewal, K., Tvingstedt, K., Gadisa, A., Inganäs, O., Manca, J.V., Relating the open-circuit voltage to interface molecular properties of donor:acceptor bulk heterojunction solar cells, Phys. Rev. B - Condens. Matter Mater. Phys. 2010; 81(12). DOI: 10.1103/PhysRevB.81.125204.

[30] Duan, C., Huang, F., Cao, Y., Solution processed thick film organic solar cells, Polym. Chem. 2015; DOI: 10.1039/C5PY01340B.

[31] Lakhwani, G., Rao, A., Friend, R.H., Bimolecular Recombination in Organic Photovoltaics, Annu. Rev. Phys. Chem. 2014; 65 , pp. 557-581. DOI: 10.1146/annurev-physchem-040513103615.

[32] Lai, T.-H., Tsang, S.-W., Manders, J.R., Chen, S., So, F., Properties of interlayer for organic photovoltaics, Mater. Today. 2013; 16(11) , pp. 424-432. DOI: 10.1016/j.mattod.2013.10.001.

[33] Azzopardi, B., Emmott, C.J.M., Urbina, A., Krebs, F.C., Mutale, J., Nelson, J., Economic assessment of solar electricity production from organic-based photovoltaic modules in a domestic environment, Energy Environ. Sci. 2011; 4(10) , pp. 3741-3753. DOI: 10.1039/C1EE01766G. 
[34] Emmott, C.J.M., Röhr, J.A., Campoy-Quiles, M., Kirchartz, T., Urbina, A., Ekins-Daukes, N.J., Nelson, J., Organic photovoltaic greenhouses: A unique application for semi-transparent PV?, Energy Environ. Sci. 2015; 8(4) , pp. 1317-1328. DOI: 10.1039/c4ee03132f.

[35] Hedstrom, S., Henriksson, P., Wang, E., Andersson, M.R., Persson, P., Light-harvesting capabilities of low band gap donor-acceptor polymers, Phys. Chem. Chem. Phys. 2014; 16(45), pp. 24853-24865. DOI: 10.1039/C4CP03191A.

[36] Holm, R.T., Palik, E.D., Handbook of Optical Constants “Convention Confusions,” Academic Press, 1991.

[37] Collins, R.W., Koh, J., Dual rotating-compensator multichannel ellipsometer: Instrument design for real-time Mueller matrix spectroscopy of surfaces and films, J. Opt. Soc. Am. A Opt. Image Sci. Vis. 1999; 16(8) , pp. 1997-2006.

[38] Johs, B., Hale, J.S., Dielectric function representation by B-splines, Phys. Status Solidi Appl. Mater. Sci. 2008; 205(4) , pp. 715-719. DOI: 10.1002/pssa.200777754.

[39] Järrendahl, K., Arwin, H., Multiple sample analysis of spectroscopic ellipsometry data of semitransparent films, Thin Solid Films. 1998; 313-314 , pp. 114-118.

[40] Bruggeman, D.A.G., Berechnung verschiedener physikalischer Konstanten von heterogenen Substanzen. I. Dielektrizitätskonstanten und Leitfähigkeiten der Mischkörper aus isotropen Substanzen, Ann. Phys. 1935; 416(7) , pp. 636-664. DOI: 10.1002/andp.19354160705.

[41] Persson, N.-K., Arwin, H., Inganas, O., Optical optimization of polyfluorene-fullerene blend photodiodes, J. Appl. Phys. 2005; 97(3) , p. -. DOI: http://dx.doi.org/10.1063/1.1836005.

[42] Campoy-Quiles, M., Müller, C., Garriga, M., Wang, E., Inganäs, O., Alonso, M.I., On the complex refractive index of polymer:fullerene photovoltaic blends, 6th Int. Conf. Spectrosc. Ellipsom. ICSE-VI. 2014; 571, Part 3 , pp. 371-376. DOI: 10.1016/j.tsf.2014.02.096.

[43] Cook, S., Ohkita, H., Kim, Y., Benson-Smith, J.J., Bradley, D.D.C., Durrant, J.R., A photophysical study of PCBM thin films, Chem. Phys. Lett. 2007; 445(4-6) , pp. 276-280. DOI: 10.1016/j.cplett.2007.08.005.

[44] Guilbert, A.A.Y., Schmidt, M., Bruno, A., Yao, J., King, S., Tuladhar, S.M., Kirchartz, T., Alonso, M.I., Goñi, A.R., Stingelin, N., Haque, S.A., Campoy-Quiles, M., Nelson, J., Spectroscopic evaluation of mixing and crystallinity of fullerenes in bulk heterojunctions, $A d v$. Funct. Mater. 2014; 24(44) , pp. 6972-6980. DOI: 10.1002/adfm.201401626.

[45] Campoy-Quiles, M., Etchegoin, P.G., Bradley, D.D.C., On the optical anisotropy of conjugated polymer thin films, Phys. Rev. B - Condens. Matter Mater. Phys. 2005; 72(4). DOI: 10.1103/PhysRevB.72.045209.

[46] Pettersson, L.A.A., Roman, L.S., Inganäs, O., Modeling photocurrent action spectra of photovoltaic devices based on organic thin films, J. Appl. Phys. 1999; 86(1) , pp. 487-496.

[47] Kim, J., Jung, S., Jeong, I., Optical modeling for polarization-dependent optical power dissipation of thin-film organic solar cells at oblique incidence, J. Opt. Soc. Korea. 2012; 16(1) pp. 6-12. DOI: 10.3807/JOSK.2012.16.1.006.

[48] Young, M., Traverse, C.J., Pandey, R., Barr, M.C., Lunt, R.R., Angle dependence of transparent photovoltaics in conventional and optically inverted configurations., Appl. Phys. Lett. 2013; 103(13) , pp. 133304-133304-5.

[49] Tress, W., Merten, A., Furno, M., Hein, M., Leo, K., Riede, M., Correlation of absorption profile and fill factor in organic solar cells: The role of mobility imbalance, Adv. Energy Mater. 2013; 3(5) , pp. 631-638. DOI: 10.1002/aenm.201200835.

[50] Burkhard, G.F., Hoke, E.T., McGehee, M.D., Accounting for interference, scattering, and electrode absorption to make accurate internal quantum efficiency measurements in organic and other thin solar cells, Adv. Mater. 2010; 22(30), pp. 3293-3297. DOI: 10.1002/adma.201000883.

[51] Kroon, R., Melianas, A., Zhuang, W., Bergqvist, J., Diaz de Zerio Mendaza, A., Steckler, T.T., Yu, L., Bradley, S.J., Musumeci, C., Gedefaw, D., Nann, T., Amassian, A., Muller, C., Inganas, O., Andersson, M.R., Comparison of selenophene and thienothiophene incorporation into 
pentacyclic lactam-based conjugated polymers for organic solar cells, Polym. Chem. 2015; DOI: 10.1039/C5PY01245G.

[52] Tvingstedt, K., Inganäs, O., Electrode grids for ITO-free organic photovoltaic devices, Adv. Mater. 2007; 19(19) , pp. 2893-2897. DOI: 10.1002/adma.200602561.

[53] Krebs, F.C., Søndergaard, R., Jørgensen, M., Printed metal back electrodes for R2R fabricated polymer solar cells studied using the LBIC technique, Sol. Energy Mater. Sol. Cells. 2011; 95(5) , pp. 1348-1353. DOI: 10.1016/j.solmat.2010.11.007.

[54] Dos Reis Benatto, G.A., Roth, B., Madsen, M.V., Hösel, M., Søndergaard, R.R., Jørgensen, M., Krebs, F.C., Carbon: The Ultimate Electrode Choice for Widely Distributed Polymer Solar Cells, Adv. Energy Mater. 2014; 4(15). DOI: 10.1002/aenm.201400732.

[55] Zhou, Y., Cheun, H., Choi, S., Potscavage Jr., W.J., Fuentes-Hernandez, C., Kippelen, B., Indium tin oxide-free and metal-free semitransparent organic solar cells, Appl. Phys. Lett. 2010; 97(15). DOI: 10.1063/1.3499299.

[56] Pettersson, L.A.., Ghosh, S., Inganäs, O., Optical anisotropy in thin films of poly(3,4ethylenedioxythiophene)-poly(4-styrenesulfonate), Org. Electron. 2002; 3(3-4) , pp. 143-148. DOI: 10.1016/S1566-1199(02)00051-4.

[57] Stathopoulos, N.A., Palilis, L.C., Yesayan, S.R., Savaidis, S.P., Vasilopoulou, M., Argitis, P., A transmission line model for the optical simulation of multilayer structures and its application for oblique illumination of an organic solar cell with anisotropic extinction coefficient, J. Appl. Phys. 2011; 110(11). DOI: 10.1063/1.3662952.

[58] Lekner, J., Reflection and refraction by uniaxial crystals, J. Phys. Condens. Matter. 1991; 3(32), pp. 6121-6133. DOI: 10.1088/0953-8984/3/32/017.

[59] Treat, N.D., Chabinyc, M.L., Phase separation in bulk heterojunctions of semiconducting polymers and fullerenes for photovoltaics, Annu. Rev. Phys. Chem. 2014; 65 , pp. 59-81. DOI: 10.1146/annurev-physchem-040513-103712.

[60] Huang, Y., Kramer, E.J., Heeger, A.J., Bazan, G.C., Bulk Heterojunction Solar Cells: Morphology and Performance Relationships, Chem. Rev. 2014; 114(14) , pp. 7006-7043. DOI: 10.1021/cr400353v.

[61] Noriega, R., Rivnay, J., Vandewal, K., Koch, F.P.V., Stingelin, N., Smith, P., Toney, M.F., Salleo, A., A general relationship between disorder, aggregation and charge transport in conjugated polymers, Nat. Mater. 2013; 12(11) , pp. 1038-1044. DOI: 10.1038/nmat3722.

[62] Hoppe, H., Niggemann, M., Winder, C., Kraut, J., Hiesgen, R., Hinsch, A., Meissner, D., Sariciftci, N.S., Nanoscale Morphology of Conjugated Polymer/Fullerene-Based BulkHeterojunction Solar Cells, Adv. Funct. Mater. 2004; 14(10) , pp. 1005-1011. DOI: 10.1002/adfm.200305026.

[63] Tait, J.G., Merckx, T., Li, W., Wong, C., Gehlhaar, R., Cheyns, D., Turbiez, M., Heremans, P., Determination of solvent systems for blade coating thin film photovoltaics, Adv. Funct. Mater. 2015; 25(22) , pp. 3393-3398. DOI: 10.1002/adfm.201501039.

[64] Hansson, R., Ericsson, L.K.E., Holmes, N.P., Rysz, J., Opitz, A., Campoy-Quiles, M., Wang, E., Barr, M.G., Kilcoyne, A.L.D., Zhou, X., Dastoor, P., Moons, E., Vertical and lateral morphology effects on solar cell performance for a thiophene-quinoxaline copolymer:PC70BM blend, J. Mater. Chem. A. 2015; 3(13) , pp. 6970-6979. DOI: 10.1039/C5TA00683J.

[65] Van Franeker, J.J., Turbiez, M., Li, W., Wienk, M.M., Janssen, R.A.J., A real-time study of the benefits of co-solvents in polymer solar cell processing, Nat. Commun. 2015; 6. DOI: 10.1038/ncomms7229.

[66] Schmidt-Hansberg, B., Klein, M.F.G., Peters, K., Buss, F., Pfeifer, J., Walheim, S., Colsmann, A., Lemmer, U., Scharfer, P., Schabel, W., In situ monitoring the drying kinetics of knife coated polymer-fullerene films for organic solar cells, J. Appl. Phys. 2009; 106(12). DOI: 10.1063/1.3270402.

[67] van Franeker, J.J., Westhoff, D., Turbiez, M., Wienk, M.M., Schmidt, V., Janssen, R.A.J., Controlling the Dominant Length Scale of Liquid-Liquid Phase Separation in Spin-coated 
Organic Semiconductor Films, Adv. Funct. Mater. 2015; 25(6) , pp. 855-863. DOI:

10.1002/adfm.201403392.

[68] Gedde, U., Polymer Physics, Kluwer Academic Publishers, 1999.

[69] Collins, B.A., Gann, E., Guignard, L., He, X., McNeill, C.R., Ade, H., Molecular miscibility of polymer-fullerene blends, J. Phys. Chem. Lett. 2010; 1(21) , pp. 3160-3166. DOI: 10.1021/jz101276h.

[70] Chen, D., Liu, F., Wang, C., Nakahara, A., Russell, T.P., Bulk heterojunction photovoltaic active layers via bilayer interdiffusion, Nano Lett. 2011; 11(5) , pp. 2071-2078. DOI: 10.1021/nl200552r.

[71] Kouijzer, S., Michels, J.J., Van Den Berg, M., Gevaerts, V.S., Turbiez, M., Wienk, M.M., Janssen, R.A.J., Predicting morphologies of solution processed polymer:Fullerene blends, J. Am. Chem. Soc. 2013; 135(32) , pp. 12057-12067. DOI: 10.1021/ja405493j.

[72] Nilsson, S., Bernasik, A., Budkowski, A., Moons, E., Morphology and Phase Segregation of Spin-Casted Films of Polyfluorene/PCBM Blends, Macromolecules. 2007; 40(23) , pp. 82918301. DOI: 10.1021/ma070712a.

[73] Schmidt-Hansberg, B., Sanyal, M., Klein, M.F.G., Pfaff, M., Schnabel, N., Jaiser, S., Vorobiev, A., Müller, E., Colsmann, A., Scharfer, P., Gerthsen, D., Lemmer, U., Barrena, E., Schabel, W., Moving through the phase diagram: Morphology formation in solution cast polymer-fullerene blend films for organic solar cells, ACS Nano. 2011; 5(11) , pp. 8579-8590. DOI: 10.1021/nn2036279.

[74] Li, G., Yao, Y., Yang, H., Shrotriya, V., Yang, G., Yang, Y., “Solvent Annealing” Effect in Polymer Solar Cells Based on Poly(3-hexylthiophene) and Methanofullerenes, Adv. Funct. Mater. 2007; 17(10) , pp. 1636-1644. DOI: 10.1002/adfm.200600624.

[75] Schmidt-Hansberg, B., Baunach, M., Krenn, J., Walheim, S., Lemmer, U., Scharfer, P., Schabel, W., Spatially resolved drying kinetics of multi-component solution cast films for organic electronics, Chem. Eng. Process. Process Intensif. 2011; 50(5-6) , pp. 509-515. DOI: 10.1016/j.cep.2010.12.012.

[76] Chou, K.W., Yan, B., Li, R., Li, E.Q., Zhao, K., Anjum, D.H., Alvarez, S., Gassaway, R., Biocca, A., Thoroddsen, S.T., Hexemer, A., Amassian, A., Spin-cast bulk heterojunction solar cells: A dynamical investigation, Adv. Mater. 2013; 25(13), pp. 1923-1929. DOI: 10.1002/adma.201203440.

[77] Pearson, A.J., Wang, T., Dunbar, A.D.F., Yi, H., Watters, D.C., Coles, D.M., Staniec, P.A., Iraqi, A., Jones, R.A.L., Lidzey, D.G., Morphology development in amorphous polymer: Fullerene photovoltaic blend films during solution casting, Adv. Funct. Mater. 2014; 24(5), pp. 659-667. DOI: 10.1002/adfm.201301922.

[78] Heriot, S.Y., Jones, R.A.L., An interfacial instability in a transient wetting layer leads to lateral phase separation in thin spin-cast polymer-blend films, Nat. Mater. 2005; 4(10) , pp. 782-786. DOI: 10.1038/nmat1476.

[79] Jukes, P.C., Heriot, S.Y., Sharp, J.S., Jones, R.A.L., Time-Resolved Light Scattering Studies of Phase Separation in Thin Film Semiconducting Polymer Blends during Spin-Coating, Macromolecules. 2005; 38(6) , pp. 2030-2032. DOI: 10.1021/ma0477145.

[80] Huang, Y., Kramer, E.J., Heeger, A.J., Bazan, G.C., Bulk Heterojunction Solar Cells: Morphology and Performance Relationships, Chem. Rev. 2014; 114(14) , pp. 7006-7043. DOI: 10.1021/cr400353v.

[81] Andersson, B.V., Herland, A., Masich, S., Olle Inganäs, Imaging of the 3D Nanostructure of a Polymer Solar Cell by Electron Tomography, Nano Lett. 2009; 9(2) , pp. 853-855. DOI: 10.1021/nl803676e.

[82] Burroughes, J.H., Bradley, D.D.C., Brown, A.R., Marks, R.N., Mackay, K., Friend, R.H., Burns, P.L., Holmes, A.B., Light-emitting diodes based on conjugated polymers, Nature. 1990; 347(6293), pp. 539-541.

[83] Reese, M.O., Gevorgyan, S.A., Jørgensen, M., Bundgaard, E., Kurtz, S.R., Ginley, D.S., Olson, D.C., Lloyd, M.T., Morvillo, P., Katz, E.A., Elschner, A., Haillant, O., Currier, T.R., Shrotriya, 
V., Hermenau, M., Riede, M., Kirov, K.R., Trimmel, G., Rath, T., Inganäs, O., Zhang, F., Andersson, M., Tvingstedt, K., Lira-Cantu, M., Laird, D., McGuiness, C., Gowrisanker, S., Pannone, M., Xiao, M., Hauch, J., Steim, R., Delongchamp, D.M., Rösch, R., Hoppe, H., Espinosa, N., Urbina, A., Yaman-Uzunoglu, G., Bonekamp, J.-B., Van Breemen, A.J.J.M., Girotto, C., Voroshazi, E., Krebs, F.C., Consensus stability testing protocols for organic photovoltaic materials and devices, Sol. Energy Mater. Sol. Cells. 2011; 95(5) , pp. 1253-1267. DOI: 10.1016/j.solmat.2011.01.036.

[84] Verploegen, E., Mondal, R., Bettinger, C.J., Sok, S., Toney, M.F., Bao, Z., Effects of thermal annealing upon the morphology of polymer-fullerene blends, Adv. Funct. Mater. 2010; 20(20), pp. 3519-3529. DOI: 10.1002/adfm.201000975.

[85] Kim, Y., Cook, S., Tuladhar, S.M., Choulis, S.A., Nelson, J., Durrant, J.R., Bradley, D.D.C., Giles, M., McCulloch, I., Ha, C.-S., Ree, M., A strong regioregularity effect in self-organizing conjugated polymer films and high-efficiency polythiophene:fullerene solar cells, Nat. Mater. 2006; 5(3) , pp. 197-203. DOI: 10.1038/nmat1574.

[86] Kim, Y., Yeom, H.R., Kim, J.Y., Yang, C., High-efficiency polymer solar cells with a costeffective quinoxaline polymer through nanoscale morphology control induced by practical processing additives, Energy Environ. Sci. 2013; 6(6) , pp. 1909-1916. DOI: 10.1039/c3ee00110e.

[87] Wang, E., Hou, L., Wang, Z., Hellström, S., Zhang, F., Inganäs, O., Andersson, M.R., An easily synthesized blue polymer for high-performance polymer solar cells, Adv. Mater. 2010; 22(46), pp. 5240-5244. DOI: 10.1002/adma.201002225.

[88] Andersson, L.M., Fully Slot-Die-Coated All-Organic Solar Cells, Energy Technol. 2015; 3(4) , pp. 437-442. DOI: 10.1002/ente.201402153.

[89] Lindqvist, C., Wang, E., Andersson, M.R., Müller, C., Facile monitoring of fullerene crystallization in polymer solar cell blends by UV-vis spectroscopy, Macromol. Chem. Phys. 2014; 215(6) , pp. 530-535. DOI: 10.1002/macp.201300717.

[90] Lindqvist, C., Bergqvist, J., Feng, C.-C., Gustafsson, S., Bäcke, O., Treat, N.D., Bounioux, C., Henriksson, P., Kroon, R., Wang, E., Sanz-Velasco, A., Kristiansen, P.M., Stingelin, N., Olsson, E., Inganäs, O., Andersson, M.R., Müller, C., Fullerene nucleating agents: A route towards thermally stable photovoltaic blends, Adv. Energy Mater. 2014; 4(9). DOI: 10.1002/aenm.201301437.

[91] Lindqvist, C., Bergqvist, J., Bäcke, O., Gustafsson, S., Wang, E., Olsson, E., Inganäs, O., Andersson, M.R., Müller, C., Fullerene mixtures enhance the thermal stability of a noncrystalline polymer solar cell blend, Appl. Phys. Lett. 2014; 104(15). DOI: 10.1063/1.4870997.

[92] Busse, G., Wu, D., Karpen, W., Thermal wave imaging with phase sensitive modulated thermography, J. Appl. Phys. 1992; 71(8) , pp. 3962-3965. DOI: 10.1063/1.351366.

[93] Breitenstein, O., Bauer, J., Hinken, D., Bothe, K., The reliability of thermography- and luminescence-based series resistance and saturation current density imaging, Sol. Energy Mater. Sol. Cells. 2015; 137 , pp. 50-60. DOI: 10.1016/j.solmat.2015.01.017.

[94] Fuyuki, T., Kondo, H., Yamazaki, T., Takahashi, Y., Uraoka, Y., Photographic surveying of minority carrier diffusion length in polycrystalline silicon solar cells by electroluminescence, Appl. Phys. Lett. 2005; 86(26) , pp. 1-3. DOI: 10.1063/1.1978979.

[95] Würfel, P., Trupke, T., Puzzer, T., Schäffer, E., Warta, W., Glunz, S.W., Diffusion lengths of silicon solar cells from luminescence images, J. Appl. Phys. 2007; 101(12). DOI: 10.1063/1.2749201.

[96] David Zook, J., Evaluation of silicon-on-ceramic using light-beam-induced currents, Sol. Cells. 1980; 1(3) , pp. 273-274. DOI: 10.1016/0379-6787(80)90076-9.

[97] Rand, B.P., Richter, H., Organic solar cells Fundamentals, Devices and Upscaling, Pan Stanford Publishing Pte. Ltd., USA, 2014.

[98] Bachmann, J., Buerhop-Lutz, C., Deibel, C., Riedel, I., Hoppe, H., Brabec, C.J., Dyakonov, V., Organic solar cells characterized by dark lock-in thermography, Sol. Energy Mater. Sol. Cells. 2010; 94(4) , pp. 642-647. DOI: 10.1016/j.solmat.2009.11.006. 
[99] Seeland, M., Rösch, R., Muhsin, B., Gobsch, G., Hoppe, H., Electroluminescence as characterization tool for polymer solar cells and modules, in: Energy Procedia, Elsevier BV, 2011: pp. 167-172. DOI: 10.1016/j.egypro.2012.11.179.

[100] Rosch, R., Tanenbaum, D.M., Jorgensen, M., Seeland, M., Barenklau, M., Hermenau, M., Voroshazi, E., Lloyd, M.T., Galagan, Y., Zimmermann, B., Wurfel, U., Hosel, M., Dam, H.F., Gevorgyan, S.A., Kudret, S., Maes, W., Lutsen, L., Vanderzande, D., Andriessen, R., TeranEscobar, G., Lira-Cantu, M., Rivaton, A., Uzunoglu, G.Y., Germack, D., Andreasen, B., Madsen, M.V., Norrman, K., Hoppe, H., Krebs, F.C., Investigation of the degradation mechanisms of a variety of organic photovoltaic devices by combination of imaging techniquesthe ISOS-3 inter-laboratory collaboration, Energy Environ. Sci. 2012; 5(4) , pp. 6521-6540. DOI: 10.1039/C2EE03508A.

[101]Feron, K., Nagle, T.J., Rozanski, L.J., Gong, B.B., Fell, C.J., Spatially resolved photocurrent measurements of organic solar cells: Tracking water ingress at edges and pinholes, Sol. Energy Mater. Sol. Cells. 2013; 109 , pp. 169-177. DOI: 10.1016/j.solmat.2012.10.027.

[102] Voroshazi, E., Verreet, B., Buri, A., Müller, R., Di Nuzzo, D., Heremans, P., Influence of cathode oxidation via the hole extraction layer in polymer:fullerene solar cells, Org. Electron. 2011; 12(5) , pp. 736-744. DOI: 10.1016/j.orgel.2011.01.025.

[103] Proctor, C.M., Kuik, M., Nguyen, T.-Q., Charge carrier recombination in organic solar cells, Top. Issue Conduct. Polym. 2013; 38(12) , pp. 1941-1960. DOI: 10.1016/j.progpolymsci.2013.08.008.

[104]Tress, W., Organic Solar Cells Theory, Experiment, and Device Simulation, Springer, 2014.

[105] Krebs, F.C., Jørgensen, M., 2D Characterization of OPV from Single and Tandem Cells to Fully Roll-to-Roll Processed Modules with and without Electrical Contact, Adv. Opt. Mater. 2014; 2(5) , pp. 465-477. DOI: 10.1002/adom.201400016.

[106] Hoppe, H., Bachmann, J., Muhsin, B., Drüe, K.-H., Riedel, I., Gobsch, G., Buerhop-Lutz, C., Brabec, C.J., Dyakonov, V., Quality control of polymer solar modules by lock-in thermography, J. Appl. Phys. 2010; 107(1). DOI: 10.1063/1.3272709.

[107] Besold, S., Hoyer, U., Bachmann, J., Swonke, T., Schilinsky, P., Steim, R., Brabec, C.J., Quantitative imaging of shunts in organic photovoltaic modules using lock-in thermography, Sol. Energy Mater. Sol. Cells. 2014; 124 , pp. 133-137. DOI: 10.1016/j.solmat.2014.01.030.

[108] Rösch, R., Krebs, F.C., Tanenbaum, D.M., Hoppe, H., Quality control of roll-to-roll processed polymer solar modules by complementary imaging methods, Dedic. Glob. Org. Photovolt. GOPV Conf. Hangzhou China. 2012; 97 , pp. 176-180. DOI: 10.1016/j.solmat.2011.10.005.

[109] Matson, R.J., Emery, K.A., Eisgruber, I.L., Kazmerski, L.L., The large scale laser scanner: millicharacterization of photovoltaic devices and modules, Conf. 12th Eur. PV Sol. Energy Conf. 1994; 12 , pp. 1222-1225.

[110]Eisgruber, I.L., Matson, R.J., Sites, J.R., Emery, K.A., Interpretation of laser scans from thinfilm polycrystalline photovoltaic modules, in: Anon (Ed.), Conf. Rec. IEEE Photovolt. Spec. Conf., IEEE, 1994: pp. 283-286. http://www.scopus.com/inward/record.url?eid=2-s2.00028718234\&partnerID=40\&md5=08d2db2a2b806ee915738a3d44d80240 (accessed December 5, 1994).

[111] Tanenbaum, D.M., Dam, H.F., Rösch, R., Jørgensen, M., Hoppe, H., Krebs, F.C., Edge sealing for low cost stability enhancement of roll-to-roll processed flexible polymer solar cell modules, Sol. Energy Mater. Sol. Cells. 2012; 97 , pp. 157-163. DOI: 10.1016/j.solmat.2011.09.064.

[112] Vandewal, K., Widmer, J., Heumueller, T., Brabec, C.J., McGehee, M.D., Leo, K., Riede, M., Salleo, A., Increased open-circuit voltage of organic solar cells by reduced donor-acceptor interface area, Adv. Mater. 2014; 26(23) , pp. 3839-3843. DOI: 10.1002/adma.201400114. 


\section{Papers}

The articles associated with this thesis have been removed for copyright reasons. For more details about these see:

http://urn.kb.se/resolve?urn=urn:nbn:se:liu:diva-123035 